\title{
MODERNIZAÇÃO E DISTRIBUIÇÃO DE RENDA \\ NA AGRICULTURA NO ESTADO DA BAHIA EM 1980
}

EUGENIA TRONCOSO LEONE

ORIENTADOR: PrOF. RODOLFO HOFFMANN

Dissertação apresentada à Escola Superior de Agricultura "Luiz de Queiroz", da Universidade de São Paulo, para obtenção do título de Mestre em Agronomia, área de concentração: Economia Agrária

PIRACICABA

Estado de São Paulo - Brasil

Abril - 1988 
Para Valéria, Carolina e

Paulo Alfredo, meus filhos 


\section{AGRADECIMENTOS}

Quero deixàr agui o meu agradecimento a três pessoas que, pela orientação, colaboração e apoio, foram fundamentais para a realização deste trabalho: Rodolfo Hoffmann (orientador), Angela A. Kageyama e Paulo Baltar.

Agradeço também aos professores Evaristo Marzä bal Neves e zilda paes de Barros Mattos pela leitura do trabaTho antes de sua versão final e a Vera Lucy Garcia pelo trabaIho de datilografia.

A FINEP - Financiadora de Estudos e Projetos, através da Fundação de Estudośs Agrários "Luiz de Queiroz" - FEAlQ (Convênio no 42.87.0536.00), forneceu o suporte financeiro para a elaboração desta dissertação. 
fNDICE.

Página

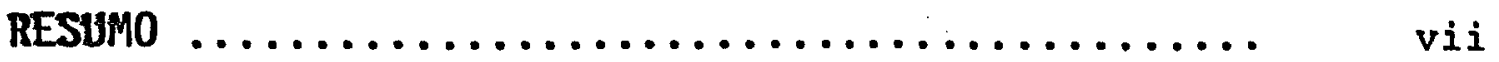

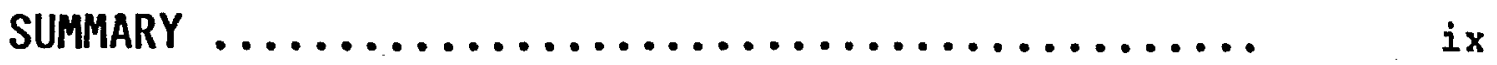

1. INTRODUÇ̃̃O $\ldots \ldots \ldots \ldots \ldots \ldots \ldots \ldots \ldots \ldots \ldots \ldots \ldots$

2. REVISÃO BIBLIOGRÁFICA $\ldots \ldots \ldots \ldots \ldots \ldots \ldots \ldots \ldots$

3. METODOLOGIA........................ 23

3.1. Esquema Geral da Metodologia e Seleção da área de estudo $\ldots \ldots \ldots \ldots \ldots \ldots \ldots \ldots$

3.2. Escolha dos Indicadores de Modernização .. 29

3.3. Indicadores de Distribuição de Renda .... 49

3.4. Análise de Componentes Principais e Regressões Lineares Múltiplas ......... 61

4. ANÁLISE DOS RESULTADOS ................ 76

4.1. Uma Caracterização Preliminar da Agropecuéria da Bahia $\ldots \ldots \ldots \ldots \ldots \ldots \ldots \ldots \ldots$

4.2. Identificação dos fatores $\ldots \ldots \ldots \ldots \ldots \ldots$

4.3. A modernização agrícola da Bahia: Uma tentativa de Caracterização Regional a partir dos fatores 
4.4. Relações entre Modernização e Distribuição de Renda no setor agropecuário em 1980 ...

5. RESUMO E CONCLUSÕES .......................

BIBLIOGRAFIA CITADA $\ldots \ldots \ldots \ldots \ldots \ldots \ldots \ldots \ldots . ., 136$

ANEXOS:

Anexo 1: Mão-de-obra em equivalentes-homem (E.H.) 140 Anexo 2: Tabelas

Tabela A2.1: Variáveis indicadoras do grau de modernização a nível de microrregião para o estado da Bahia em 1980 ...... 143

Tabela A2.2: Renda média por pessoa, indicadores de desigualdade e de pobreza, considerando a PEA na agropecuária em 1980, excluindo os que declararam renda nula, no Brasil e unidades de federação .................... $\quad 144$

Tabela A2.3: Divisão em Espaços Agrários, Bahia$-1980$

Tabela A2.4: Distribuição do valor da produção por tipo de atividade agropecuária, para as microrregiões do estado da Bahia, 1980 ................... $\quad 146$

Tabela A2.5: Valor da Produção dos principais produtos da lavoura permanente no 
ano de 1980, segundo as microrregiões do estado da Bahia $(\%) . . . .$. .

Tabela A2.6: Valor da Produção dos principais produtos da lavoura temporária no ano de 1980 segundo as microrregiões do estado da Bahia $(\%) \ldots \ldots \ldots \ldots$.

Tabela A2.7: Estabelecimentos segundo grupos de área total $(\%)$, Não assalariados (\% no pessoal ocupado em E.H.) e Pobres (\%na PEA agropecuéria) segundo as microrregiões do estado da

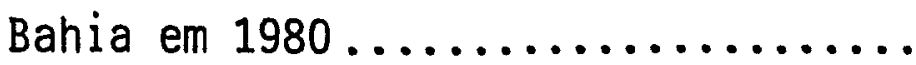

Tabela A2.8: Distribuição da PEA e das pessoas pobres economicamente ativas na agropecuária, extração vegetal e pesca, classificadas como empregados (EMP), autônomos (AUT) ou empregadores (patröes, PAT), na Bahia e no Nordeste (excluida a Bahia)

Tabela A2.9: População Economicamente Ativa segundo microrregiões, Bahia, 1970 e 1980. Variação na Década (Absoluta e Proporcional). Assalariados (\% no pessoal ocupado em E.H.) e Pobres (\% na PEA)......................

Anexo 3: Relação das Microrregiões Homogêneas do Estado da Bahia... 


\section{LISTA DE TABELAS}

Tabela 1: Média Aritmética e Coeficientes de Variação dos indicadores de modernização. Média das microrregiões, Bahia e Brasil, 1980 .............................

Tabela 2: Coeficientes de Correlação entre os indicadores de modernização................

Tabela 3: Renda Média por pessoa, indicadores de desigualdade e pobreza considerando a PEA na agropecuéria em 1980, excluindo os que declararam renda nula nas microrregiões do estado da Bahia e no Brasil

Tabela 4: Correlações de Pearson dos indicadores de pobreza, nivel e desigualdade de renda da PEA na agropecuária em $1980 \ldots \ldots$...

Tabela 5: Distribuição da-PEA agrícola segundo faixas de salários minimos mensais da Bahia em 1980, excluindo os que declararam renda nula........................ 58

Tabela 6: Matriz A. (Coeficientes de correlação entre as variáveis originais e os primeiros três fatores).................... 
Tabela 7: Fatores de ponderação das observações, utilizados na análise ponderada........

Tabela 8: Matriz A após rotação pelo método VARIMAX (considerando só os três primeiros fa-

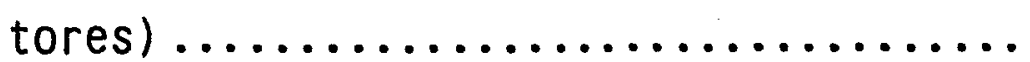

Tabela 9 Matriz F. Valor dos três primeiros fatores para as microrregiões do estado da

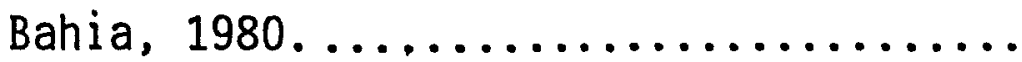

Tabela 10: Perfis Distributivos e Estrutura de Trabalho, Bahia, $1980 \ldots \ldots \ldots \ldots \ldots \ldots$

Tabela 11: Resultados das regressões lineares (ponderadas pela PEA) entre indicadores de renda e de modernização da agricultura

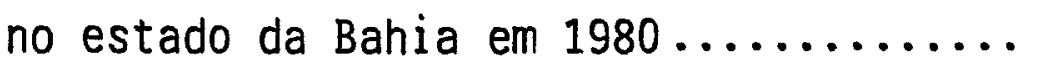

Tabela 12: Resultados das regressões quadráticas (ponderadas pela PEA) entre os indicadores de renda e de modernização da agricultura no estado da Bahia em 1980..... 


\section{LISTA DE FIGURAS E MAPAS}

Figura 1: Valores dos fatores F1 e F2 por microrregiões do estado da Bahia.............. 99

Figura 2: Valores dos fatores F1 e F3 por microrregiões do estado da Bahia.............. 100

Figura 3: Valores dos fatores F2 e F3 por microrregiões do estado da Bahia ............ 101

Mapa 1: Bahia - Microrregiões ............... 25

Mapa 2: Bahia - Espaços Agrários ............. 78

Mapa 3: Bahia - Caracterização Regional a partir dos fatores, $1980 \ldots \ldots \ldots \ldots \ldots \ldots \ldots . . . \ldots 11$ 


\title{
MODERN IZAÇÃO E DISTRIBUIÇÃO DE RENDA \\ NA AGRICULTURA NO ESTADO DA BAHIA EM 1980
}

\author{
Autora: Eugênia Troncoso Leone \\ Orientador: Prof. Rodolfo Hoffmann
}

RESUMO

Este trabalho teve por objetivo testar para o estado da Bahia a hipótese de que existe uma associação direta entre o grau de modernização da agricultura e o nível e desigualdade de renda agrícola, além de que maiores níveis de modernização tendem a estar associados com menores níveis de pobreza rural.

Utilizando informações dos Censos Demográfico e Agropecuário para 1980 a nível de microrregião, construíram-se "medidas" de modernização e determinaram-se as principais características da distribuição de renda. No caso da modernização, por envolver um grande número de variáveis, empregou-se o Método dos Componentes Principais para obter 3 indicadores sintéticos (fatores) de modernização.

Constatou-se, mediante análise de regressão, que a intensidade do uso do trabalho assalariado, a escala de empreendimentos e a produtividade do trabalho (primeiro fator) contribuem para aumentar a renda média e a desigual- 
dade e reduzir a incidência de pobreza. Por sua vez, a intensidade de exploração da terra' (segundo fator) afeta positivamente o nível e desigualdade da renda. Finalmente, a intensidade do uso do solo através da utilização de "tecnologia de ponta" (terceiro fator) só afeta significativamente, de forma direta, a renda média.

Paralelamente, efetuou-se um zoneamento do estado em função dos graus de modernização. Este zoneamento teve o propósito exclusivo de servir de instrumento auxiliar para uma discussão complementar da relação entre modernização e distribuição de renda na agropecuária baiana, ajudando a explicar por que somente o primeiro fator de modernização tem uma influência significativa sobre todos os aspectos da distribuição de renda nas microrregiões. 


\title{
AGRICULTURAL MODERNIZATION AND INCOME DISTRIBUTION IN THE BAHIA STATE IN 1980
}

\author{
Author: Eugênia Troncoso Leone \\ Adviser: Prof. Rodolfo Hoffmann
}

SUMMARY

The purpose of this work was to test, using data from the state of Bahia, the hypothesis that increasing levels of modernization in agriculture are associated with higher levels of agricultural income and increasing inequality in its distribution, as well as lower levels of rural poverty .

Modernization and income distribution indicators were developed using information from the 1980 Demographic and Agricultural Census at the level of microregions ("microrregiōes"). Principal Component Analysis lead to reduce the initial large set of variables for modernization to three principal components.

The first component included the participation of hired work in total labor, scale of production and labor productivity. It was verified that the increase of this first component is related to average income, higher inequality in income distribution and lower levels of 
poverty. The intensity of land exploration (second component) is directly related only to average income and Gini indexes of income distribution. Finally, increasing intensity of land use through mecanization and irrigation is significantly related only to higher average income.

In addition, the state was divided in regions according to levels of modernization. This was used as complementary tool for explaining the fact that only the first component is related to all aspects of income distribution. 


\section{INTRODUÇÃO}

Os principais resultados do desenvolvimento econômico são aumentar a produtividade e a renda. É tradicio nal entre alguns economistas pensar que também faz parte do desenvolvimento econômico, ao menos nas suas etapas iniciais, uma mudança da distribuição de renda no sentido de um aumento na sua dispersão e desigualdade.

Isto se deve, em parte, ao fato de que no prô cesso de desenvolvimento o aumento da produtividade do trabalho nas atividades agrícolas viabiliza o deslocamento da população do campo para a cidade. Nas atividades não-agrícolas, o aumento do nível de renda seria acompanhado por crescentes diferenciaçōes òe renda entre as pessoas, e há um relativo con senso em torno destas idéias enquanto possibilidades, que se concretizarão ou não em situações particulares dependendo de condições sociais, políticas e econômicas.

Assim, não é inexorável o aumento na desigual dade da distribuição de renda com o desenvolvimento econômico, mas ele depende, entre outras, das circunstâncias politicas. 0 que existe é a potencialidade, pois o desenvolvi- 
mento capitalista implica aumento da renda global e diferenciação das atividades.

A questão que se coloca para o presente trabalho é a preocupação com o que ocorre na distribuição de renda dentro da própria agricultura quando ela se moderniza. Um dos efeitos centrais da modernização é a elevação da produtividade do trabalho. Este aumento de produtividade significa aumento de renda e, ao mesmo tempo, aumento da possibilidade de diferenciação das pessoas e das famílias com relação à renda, ou seja, possibilidade de modificações ao nível da distribuição da renda.

Em resumo, a possibilidade de aumento na desigualdade da distribuição de renda no processo de desenvolvimento está associada ao aumento geral da produtividade que caracteriza o desenvolvimento, inclusive o aumento de produtividade na agricultura.

Esta última questão é tão relevante quanto a da diferenciação campo-cidade e, de fato, como constataram HOFFMANN e KAGEYAMA (1986) nos anos 70 no Brasil, o aumento da renda média da população ativa foi maior nas atividades agrícolas que nas atividades não-agrícolas, acompanhado de maior aumento de desigualdade de renda na agricultura, a pontc de o indice de Gini em 1980 ser apenas um pouco maior nas atividades não-agrícolas. Ou seja, a distribuição de renda entre as pessoas ativas no campo tornou-se tão desigual como a das cidades. 
Lembrando que a elevação da produtividade agrícola decorre fundamentalmente da introdução de progresso técnico, o aumento na desigualdade da distribuição de renda agrícola tampouco é inexorável, e não deve ser relacionado ao progresso técnico em si mesmo. A sua concretização depende de muitos outros fatores que acompanham o progresso técnico, tais como o acesso ao crédito e extensão rural, o controle da comercialização e a influência sobre os rumos da politica agrícola.

o propósito desta dissertação é contribuir para o estudo dessa questão, analisando a diversidade de situações existentes na agricultura do estado da Bahia em 1980, utilizando os dados dos Censos Demográfico e Agropecuário, ao nível de microrregiões homogêneas.

Insistimos que não é inexorável o aumento da desigualdade de renda ao aumentar seu nível médio num processo de desenvolvimento econômico. Tudo depende da ação de muitas variáveis, algumas delas passíveis de sofrerem, em variado grau, a influência da ação do Estado. Isto aumenta a importância de se tentar compreender a complexidade da relação entre modernização e distribuição de renda, pois ela pode contribuir para orientar a ação do Estado, . visando maior eficácia na correção de possíveis tendências de crescimento da desigualdade da đistribuição de renda quando aumenta a produtividade.

o que de fato ocorre.com a distribuição de renda depende não somente do pnóprio aumento da produtivida- 
de e diversificação de atividades (pecuária, lavouras comerciais permanentes e temporárias, culturas de subsistência). mas também do modo como a propriedade da terra é repartida e a maneira como se organiza a produção, especialmente as relações de produção prevalecentes.

A simples observação das diferenças dessas variáveis entre microrregiões num determinado momento do tempo não autoriza inferir conclusões mecanicistas sobre $\circ$ que tende efetivamente a ocorrer num processo de desenvolvimento. Entretanto, constitui um passo preliminar necessário, permitindo destacar a importância relativa de cada uma das variáveis, dando indicações para estudos posteriores a respeito de como o processo de desenvolvimento econômico altera cada uma delas e seus efeitos sobre a distribuição de renda.

Este estudo faz parte de um esforço coletivo que envolve a análise de outros estados, sob orientação do professor Rodolfo Hoffmann. A existência de uma associação direta entre o grau de modernização da agricultura e a desigualdade da renda agrícola foi constatada por HOFFMANN e KAGEYAMA (1985), que também mostraram que maiores niveis de modernização da agricultura tendem a estar associados com menores níveis de pobreza rural no país. Como os autores citados trabalharam a questão ao nível do Brasil, tomando como unidades (observações) os estados, que em seu próprio interior contêm situações heterogêneas, é de interesse 
testar essas mesmas hipóteses a nível de um estado, tentando captar possiveis especificidades locais.

Assim, o objetivo deste trabalho é testar para o estado da Bahia, a nível de microrregião, a hipótese de que existe uma associação direta entre o grau de modernização da agricultura e o nível e desigualdade da renda agríco1a, além do que, maiores níveis de modernização tendem a estar associados com menores níveis de pobreza rural. Paralelamente, procurar-se-á fazer um zoneamento do estado da Bahia em função dos graus e tipos de modernização de sua agricultura.

Além desta introdução, compõem a dissertação mais quatro capítulos. No segundo se faz uma breve revisão bibliográfica sobre o assunto tratado; no capítulo seguinte justifica-se a escolha da Bahia como estudo de caso e apresenta-se a metodologia. No quarto capitulo discutem-se os resultados da análise e finalmente o guinto resume as conclusões. 


\section{REVISÃO BIBLIOGRÁFICA}

A literatura sobre modernização da agricultura no Brasil é muito extensa. Uma parcela razoável desta literatura foi revisada por CARVALHO (1982), notando-se que um tema que marcou a discussão sobre modernização foi a questão da diversidade tecnológica na agricultura.

Em particular, diversos trabalhos centraram-se na explicação da resistência e viabilidade econômica da agricultura tradicional. Acreditamos, entretanto, que o foco de atenção nas discussões foi-se deslocando, à medida que se ia percebendo a magnitude das transformações que estavam se processando no setor agrícola do país desde meados dos anos 60 .

Da persistência do atrasado, a discussão evoluiu para o impacto, em termos de diferenciação entre os produtores, provocado pelo avanço tecnológico da agricultura. Nesta trajetória do debate sobre o setor agrícola é possivel observar um constante esforço de superação dos limites analiticos da abordagem dualista, procurando construir uma visão integrada do tradicional e do moderno como 
partes complementares, interrelacionadas, da dinâmica do processo de transformação capitalista da agricultura, na direção de uma produção voltada plenamente para o mercado e para o lucro.

Não pretendemos reconstituir aqui sequer os incincipais momentos desta evolução. Apenas destacamos que dos temas que surgiram quase que naturalmente no novo enfogue foi o da associação entre a modernização e a concentração de renda agrícola. Alguns autores, como HOFFMANN e KAGEYAMA (1985), propõem que a modernização da agricultura, nos moldes em que ocorreu no Brasil, foi um dos principais fatores de ampliação da já elevada desigualdade de renda no campo. Essa relação direta entre modernização e concentração da renda agrícola teria como base dois elementos fundamentais: de um lado, o mais fácil acesso dos grandes produtores às técnicas avançadas, inclusive por suas vantagens no acesso ao financiamento por vias institucionais; de outro os complexos efeitos das alterações nas relações de produção e aumento no grau de monetarização das transações que acompanharam a modernização da agricultura no Brasil.

Em todo caso, os autores deixam claro que o aumento da desigualdade de renda não pode ser atribuido à natureza da nova tecnologia em si mesma. Seria mais apropriado vincular aquele fenômeno ao contexto social e institucional típico do países subdesenvolvidos em que se deu 
a modernização, o qual é marcado por fortes desigualdades estruturais.

o impacto da modernização sobre as relações de produção é um assunto complexo. Em alguns casos estimulou uma produção familiar tecnificada e moderna, estreitamente integrada à agroindústria. Noutros casos fez prevalecer a grande empresa capitalista e o trabalho assalariado. De todos os modos as inovações que acompanham o progresso agrícola tiveram efeitos importantes sobre o uso da força de trabalho. Como mostrou GRAZIANO DA SILVA (1981 e 1982), a combinação de uma mecanização parcial, que não atingiu a colheita, com um maior uso de insumos químicos, que potencializou o rendimento da terra, fez aumentar a produtividade do trabalho, mas também acentuou a sazonalidade do trabalho agrícola.

De fato, a adubação química do solo, o maior uso de tratores no plantio, de herbicidas, inseticidas e fungicidas, sem uma mecanização da colheita, modificam a distribuição do uso da mão-de-obra durante o cicló agrícola, concentrando a demanda no período em que deve ser realizada a colheita. En conseqüência desta modernização parcial da agricultura, notadamente nas áreas onde tende a preva- 
lecer a grande empresa capitalista, predominou não o empregado permanente mas o temporário. Este predomínio do emprego temporário sem dúvida tem repercutido na distribuição da renda agrícola.

No tocante à produção familiar tecnificada e moderna, ela surge de um processo de diferenciação social de pequenos produtores, em que os que não logram acompanhar as mudanças são deslocados para outras áreas de produção, ou para fora das atividades agrícolas. Este é um caso típico da diferenciação dos produtores no processo de modernização agrícola que não leva necessariamente à grande empresa e ao trabalho assalariado.

Não obstante, os grandes contrastes que subsistem na realidade agrária brasileira não parecem ser tanto resultado da diferenciação completa entre capitalistas e assalariados, mas sim da diversidade de situações entre os grandes produtores comerciais modernos e os pequenos produtores tradicionais de subsistência, não afetados diretamente pela modernização agrícola.

De modo que, em certo sentido, a antiga questão da heterogeneidade ainda é o problema central. Como mostrou KAGEYAMA (1986), houve no conjunto do país um processo global de intensificação da exploração da terra e de aumento na produtividade do trabalho, mas este processo ocorreu em ritmos muito diferentes por produtos e por regiões do país. 
Nunca é demais destacar a importância que teve, na modernização, seu estreito relacionamento com o desenvolvimento de uma série de indústrias, tanto as fornecedoras de equipamentos e insumos agrícolas quanto as processadoras de produtos oriundos da agricultura. Entretanto, também é fundamental destacar que, ao menos até recentemente, e ao contrário do que ocorreu em economias desenvolvidas, os produtores de alimentos básicos para o consumo da população foram os menos afetados pela modernização.

FAJNZYIBER (1983) chama atenção para este fato, ao apontar os desajustes no relacionamento agricultura-indústria, não só no Brasil mas em toda a América latina, comparativamente ao sucedido nos paises desenvolvidos, durante o pós-guerra. Interessa aqui destacar a relação entre esse fenômeno e o fato de o Brasil ainda ter uma grande parcela da população no campo. Essa relação é particularmente verdadeira no caso do Nordeste, onde grandes contingentes de população sobrevivem na pequena produção de alimentos básicos como feijão, mandioca e milho, vendendo o excedente da produção sobre o consumo familiar.

Não obstante, mesmo no Nordeste a modernização, embora indiretamente, tem afetado de modo significativo a pequena produção de alimentos básicos. Esses efeitos operam através de mudanças nas relações entre os pequenos e grandes produtores. CARNEIRO (1982), reunindo resul- 
tados de pesquisa de diversos autores; mostra sinteticamente como se processam essas mudanças na zona da Mata, no Agreste e no Sertão Nordestino.

Na produção canavieira da Zona da Mata a substituição do engenho pela usina, que se acentuou desde os anos 50, foi acompanhada pela eliminação da figura do morador, que se proletarizou. A conversão do morador em assalariado significou a expulsão do trabalhador do campo, onde antes cultivava lavouras de subsistência em áreas não usadas na plantação de cana. Esses trabalhadores passaram a residir em cidades e vilas da região, empregando-se no campo apenas nas épocas de trabalho mais intenso, notadamente na colheita da canal.

Na região policultora do Agreste, o que afetou as condições da pequena produção não foi propriamente a modernização đa lavoura mas a pecuarização. Trata-se de uma região tradicionalmente importante para o abastecimento de alimentos aos centros urbanos do Nordeste. Nela coexistiam grandes e pequenas propriedades combinando pecuária, culturas de subsistência e lavouras comerciais, notadamente de algođão.

Na grande propriedade,' em geral, a principal atividade era a pecuária. Particularmente onde o algodão era a principal cultura comercial, o grande proprietário arrendava parte de suas terras em épocas de chuvas para 1 Além de CARNEIRO (1982), vários outros autores estudaram esse processo de proletarização do morador da cana do Nordeste. Podem-se citar, por exemplo, os trabalhos de SIGAUD (1979) e SUAREZ(1977). 
aproveitar como pasto, no período de estiagem, os restos da lavoura. Este arrendamento tradicionalmente permitiu ao pequeno proprietário contornar o problema da exigüidade de suas terras.

A pecuarização do agreste nordestino, tendência que se observa desde os anos 60, levou à substituição do plantio de algodão arbóreo, cultura de ciclo relativamente longo, pelo plantio de capins e palma forrageira, Essa substituição de culturas permanentes por pastagens teve por efeito eliminar o arrendamento, resultando em crescente pressão demográfica sobre as terras da pequena propriedade, com implicações sobre o abastecimento de alimentos e o êxodo populacional.

Em resumo, apesar de não se ter modernizado, ou talvez por conta disto, as condições da pequena produção no Nordeste vêm se deteriorando, prejudicando o abastecimento de gêneros alimentícios básicos e aumentando o êxodo rural. Na explicação do por que da não modernização da pequena produção no Nordeste, papel importante parece caber às formas de organização da intermediação comercial.

$$
\text { Como afirmou GRAZIANO DA. SIIVA (1982), os }
$$

pequenos estabelecimentos que não podiam assumir um comportamento empresarial (pequenos proprietários, arrendatários, parceiros e ocupantes) ficaram na dependência de um número excessivo de intermediários comerciais. Nestas circunstâncias, não somente o preço desses produtos tende a ser maior para os consumidores, como também eventuais au-. 
mentos de preços para o consumidor dificilmente chegam a beneficiar os produtores.

Devido à extrema diversidade dos processos sociais, o tema da diṣtribuição de renda no processo de modernização da agricultura brasileira é muito complexo. Envolve a consideração tanto das conseqüências diretas da modernização - enguanto processo de diferenciação social dos produtores, que em certas circunstâncias resulta na expansão da grande empresa capitalista, e consegüentemente, proletarização da força de trabalho - como também dos efeitos indiretos da modernização sobre a pequena produção tradicional que, apesar de não mudar suas formas de produzir, nem por isso fica totalmente à margem da onda de transformação por que passa a agricultura.

Trata-se de um processo que tem um ritmo muito rápido. o perfil da agricultura brasileira mudou radicalmente em menos de uma década. HOFFMANN (1987) pesquisou as mudanças que este processo provocou na estrutura de posições na ocupação da PEA (Populaçãó Economicamente Ativa) agrícola e na distribuição de renda das várias regiões do país utilizando os dados dos censos Demográficos de 1970 e 1980.

Uma primeira constatação importante desse trabalho é que a proporção dos autônomos na PEA agrícola é menor nas regiões onde é maior o grau de modernização. Por outro lado, durante a década de 70 houve uma pronunciada diminuição nesta proporção em todas as regiões do país. 
Ambas constatações sugerem que a modernização da agricultura brasileira nos anos 70 não se caracterizou apenas por maior uso de equipamentos e insumos industriais e novas técnicas agronōmicas mas também por uma rápida mođificação nas relações de produção, com crescente assalariamento da força de trabalho.

Hoffmann também constatou que as mudanças nas relações de produção acarretaram uma modificação no perfil da pobreza agrícola. A pobreza absoluta diminuiu em todas as posições na ocupação (empregados, autônomos e empregadores) nas várias regiões. Entretanto, aumentou acentuadamente a proporção dos pobres que são assalariados.

Os dados também sugerem que a modernização da agricultura brasileira nos anos 70 modificou em profundidade o perfil do trabalhador autônomo. o número absoluto de autônomos diminuiu na década. Por outro lado, esta categoria foi a que apresentou maiores aumentos de nível e desigualdade de renda. A partir do trabalho de HOFFMANN (1987) podemos concluir que o rápido aumento da renda média não pode ser atribuido exclusivamente ao desaparecimento de autoonomos que usufruíam de nivel de renda muito baixo. Como a desigualdade de renda também aumentou, permaneceram autónomos de baixa renda ao mesmo tempo em que surgiram autōnomos de renda elevada. Em sintese, a modernização da agricultura brasileira nos anos 70 significou não somente uma crescente proletarização da força de tra- 
balho mas também uma diferenciação no interior do trabalho autônomo.

Neste trabalho pretendemos realizar um estudo empírico sobre a relação entre modernização 'e distribuição de renda e, por isto, a revisão bibliográfica será doravante dedicada basicamente a considerar questões de ordem metodológica envolvidas no estudo das relações entre distribuição de renda e modernização agrícola.

Não se pretende também fazer uma análise minuciosa de cada trabalho considerado, mas indicar aqueles que, ainda que com outros objetivos, utilizam basicamente a mesma metodologia aqui aplicada.

o Zoneamento Agrícola, 1 a Fase, publicado no Informativo Técnico $\mathrm{n} 04$ do MINISTÉRIO DA AGRICULTURA, utilizou análise fatorial para obter uma regionalização agrária do Brasil. Realizado por uma equipe do convênio INCRA/ SERPRO no ano de 1975, o projeto de zoneamento agrário do país a nível de microrregião homogênea tinha a finalidade primeira de delimitar áreas prioritárias de Reforma Agrária. Os objetivos incluiam a identificação das áreas de elevado nível tecnológico, de maior importância do assalariamento, de maior pressão demográfica e de maior éxodo rural, entre outras.

A partir do cadastro de Imóveis Rurais de 
72, do Incra, e dos Censos Agropecuário, Demográfico e Predial de 1970, selecionaram-se 50 indicadores a nível de microrregião que refletissem as peculiaridades dominantes da estrutura agrária brasileira, ou seja, que captassem os aspectos fundiários, econômicos e sociais mais relevantes de cada microrregião.

Devido ao grande número de indicadores, utilizaram-se técnicas de Análise Multivariada, em particular Análise Fatorial e Análise de Componentes Principais, para reduzir estes indicadores a um número manejável de variáveis, que são os fatores ou componentes principais.

Esta análise permitiu classificar as microrregiões segundo diversos critérios, como utilização de terra e atividade: econōmica, níveis tecnológicos, níveis de produtividade, condição do produtor, migrações internas, concentração populacional, densidade demográfica e principal produto agrícola.

Estes resultados foram apresentados sob aforma de mapas e de Iistagens por microrregião e a análise dos tipos permitiu identificar as zonas prioritárias em termos de Reforma Agrária.

FUENTES LLANILLO (1982) analisou a estrutura de produção agropecuária do estado do Paraná a nivel de microrregião, e identificou zonas diferenciais de estrutura agrária, considerando éstrutura fundiária, uso da ter- 
ra, tecnologia, capital, pessoal ocupado e relações de trabalho e recursos naturais (especialmente solos), aspectos básicos e determinantes da estrutura de produção agrícola. A caracterização foi feita em três cortes temporais, 1970, 1975 e 1980. Ele utilizou a análise fatorial para observar como as características estudadas estavam correlacionadas em 1970, 1975 e 1980, além de utilizar os valores dos fatores de 1980 para indicar as zonas diferenciais de estrutura agrária.

O trabalho "Modernização da Agricultura e Distribuição de Renda no Brasil", de HOFFMANN e KAgEYAMA (1985), está mais diretamente relacionado com o presente estudo.

O objetivo do trabalho citado foi verificar a existência de associação entre o grau de modernização da agricultura e a distribuição de renda pessoal do setor agricola no Brasil, considerando como unidades de análise as unidades da federação (estados e territórios).

Partiu-se da seleção de 29 variàveis consideradas indicadoras da modernização da agricultura. As informações sobre essas variáveis foram obtidas do Censo Agropecuário de 1975, embora os dados sobre distribuiçào da renda fossem do Censo Demográfico de 1980 .

As variáveis foram preliminarmente agrupadas em quatro conjuntos, segundo os efeitos do progresso 
técnico no desenvolvimento na agricultura:

- vàriáveis relacionadas com $a$ intensidade da exploração da terra (nove variáveis)

- variáveis relacionadas com o grau de mecanização e capacidade produtiva da força de trabalho (nove variáveis)

- variáveis relacionadas com o grau de monetarização da produção (oito variáveis)

- variáveis relacionadas com a modernizaçāo das relações de trabalho (três variáveis).

Os resultados gerais desse trabalho sugerem que os estados com maior grau de modernização têm maior renda média e que de um modo geral os estados com agricultura mais moderna tendem a apresentar menor grau de pobreza rural.

- A relação entre modernização e desigualdade é mais complicada que as anteriores, mas a grosso modo se pôde concluir que a desigualdade é crescente com o nivel de modernização da agricultura dos estados, porém ela não continua a aumentar a partir de certo nivel de modernizaçoo.

E por último, cabe comentar o capitulo "Modernização da Agricultura, Distribuição de Renda e Pobreza", que faz parte do Relatório de Pesquisa: Inovações Tec- 
nológicas e Transformações Recentes na Agricultura Brasileira, coordenado por HOFFMANN (1985), que também está diretamente relacionado com o tema ora proposto.

Este estudo teve o mesmo objetivo do trabaTho antexior, mas as informaçōes: tanto de modernização como de renda referem-se ao ano de 1980. Além disto, não se detém somente numa análise da relação entre modernização e distribuição de renda em um ano determinado, mas também analisa as mudanças no nível de modernização e na distribuição de renda no campo entre 1970 e 1980.

Tanto na análise de corte transversal quanto no acompanhamento das mudanças havidas na modernização e distribuição de renda na agricultura considerou-se o peso de cada estado em termos de sua contribuição à produção nacional (análises ponderadas).

A partir do Censo Agropecuário de 1980 foram selecionadas 14 variáveis indicadoras de modernização da agricultura, mais uma a partir do Censo Industrial de 1975, as quais foram agrupadas em cinco conjuntos segundo aspectos básicos do processo de modernização. Os conjuntos foram:

- variáveis relacionadas com a intensidade de exploração da terra (seis variáveis)

- variáveis relacionadas com a capacidade 
produtiva da força de trabalho (três variáveis)

- variáveis relacionadas com o uso de trabalho assalariado e temporário (duas variàveis)

- variáveis relacionadas com a escala do empreendimento (três variảveis)

- variável relaçionada com o desenvolvimento do complexo agroindustrial.

Quanto à análise de corte transversal das 15 variáveis selecionadas, obtiveram-se, pelo método de componentes principais, valores para três novas variáveis los três primeiros componentes principais: $c_{1}, c_{2}$, e $c_{3}$ ), que em conjunto expressam as informações contidas nas 15 ivariáveis originais e respondem por 95,38 da variância total das variáveis.

O primeiro componente $\left(c_{1}\right)$ refletiu o efeito do processo de modernização da agricultura sobre a intensidade da exploração da terra, associado ainda com a extensão do complexo agro-industrial.

O segundo componente $\left(\mathrm{C}_{2}\right)$ captou o grau de produtividade e escala de produção; e o terceiro componente $\left(c_{3}\right)$ o grau de utilização do trabalho assalariado e tem- 
porário na agricultura.

Ao relacionar os valores desses 3 fatores com as características da distribuição de renda em cada unidade de Federação, os principais resultados obtidos nesse trabalho foram:

1) Há evidência de que as diferenças de intensidade de exploração da terra e desenvolvimento do complexo agroindustrial entre os estados da federação estão positivamente associadas com as diferenças de renda per capita e com as diferenças de grau de desigualdade de sua distribuição.

2) Há evidências de que as diferenças de produtividade do trabalho e escala de produção entre os estados estão diretamente associadas com as diferenças de renda média e de desigualdade da distribuição e inversamente relacionados com a pobreza rural.

3) Há evidências de que as diferenças de extenșão de uso de assalariados e empregados temporários entre os estados estão diretamente associadas às diferenças de pobreza rural e inversamente associadas às diferenças de renda média.

- trabalho inclui uma.análise das mudanças no grau de modernização através do tempo, utilizando-se as variações relativas das variáveis indicadoras de modernizaÇão obtidas dos Censos de 1970 e 1980. Constatou-se que os aumentos da.produtividade e da escala de produção estavam 
fortemente relacionados tanto com os aumentos de renda média quanto com os aumentos da desigualdade de renda. 


\section{METODOLOGIA}

\subsection{Esquema Geral da Metodologia e Seleção da área de estudo}

A metodologia utilizada pode ser descrita em três partes: cálculo dos indicadores de modernização e distribuição de renda, análise fatorial e regressões múltiplas (ver esquema metodológico).

A área escolhida para o estudo foi o estado da Bahia, que é constituído por 26 microrregiōes homogêneas (MRHs) segundo a divisão đo IBGE. (Ver Mapa 1).

A microrregião de Salvador (150), como veremos no item 3.3., apresenta valores atípicos com relação à renda, provocando distorções na análise dos resultados, além de não ter muita importância em termos de agricultura. Provavelmente muitas pessoas ricas ligadas à agricultura baiana moram em Salvador, embora parte de sua renda possa estar sendo gerada em outras áreas, o que possivelmente explica a discrepância da renda da PEA agrícola residente na 

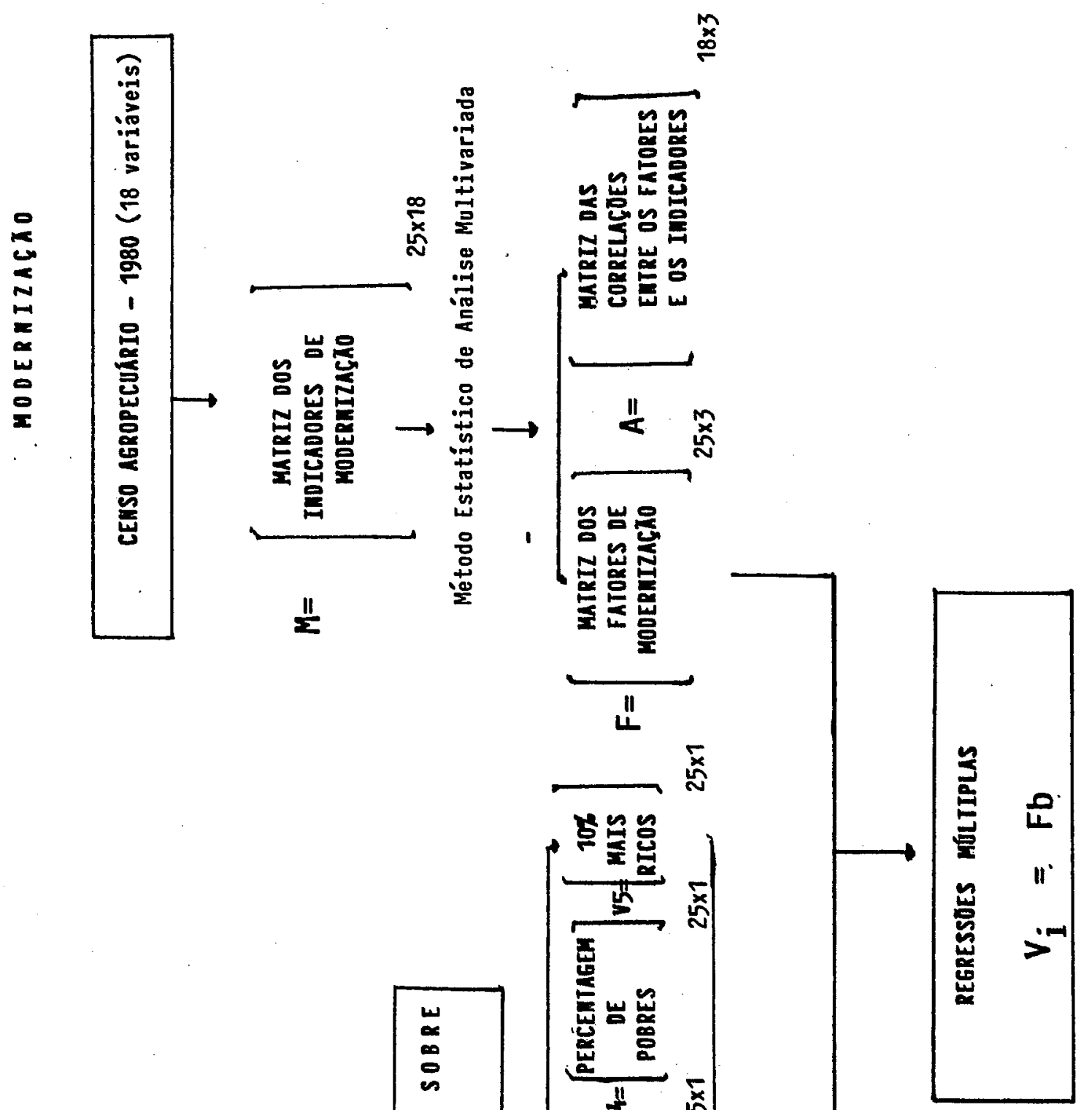

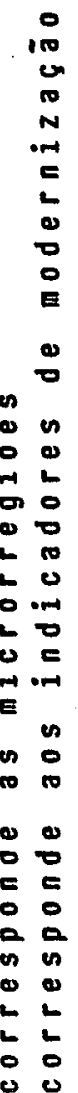

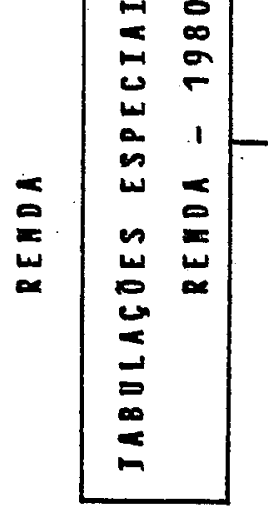

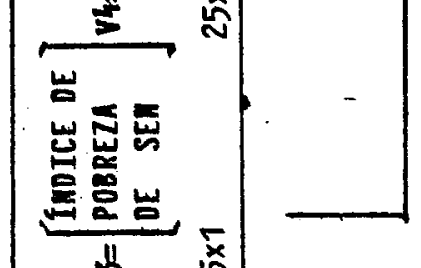

n $\infty$ N

00

는

(\$)

를

00 


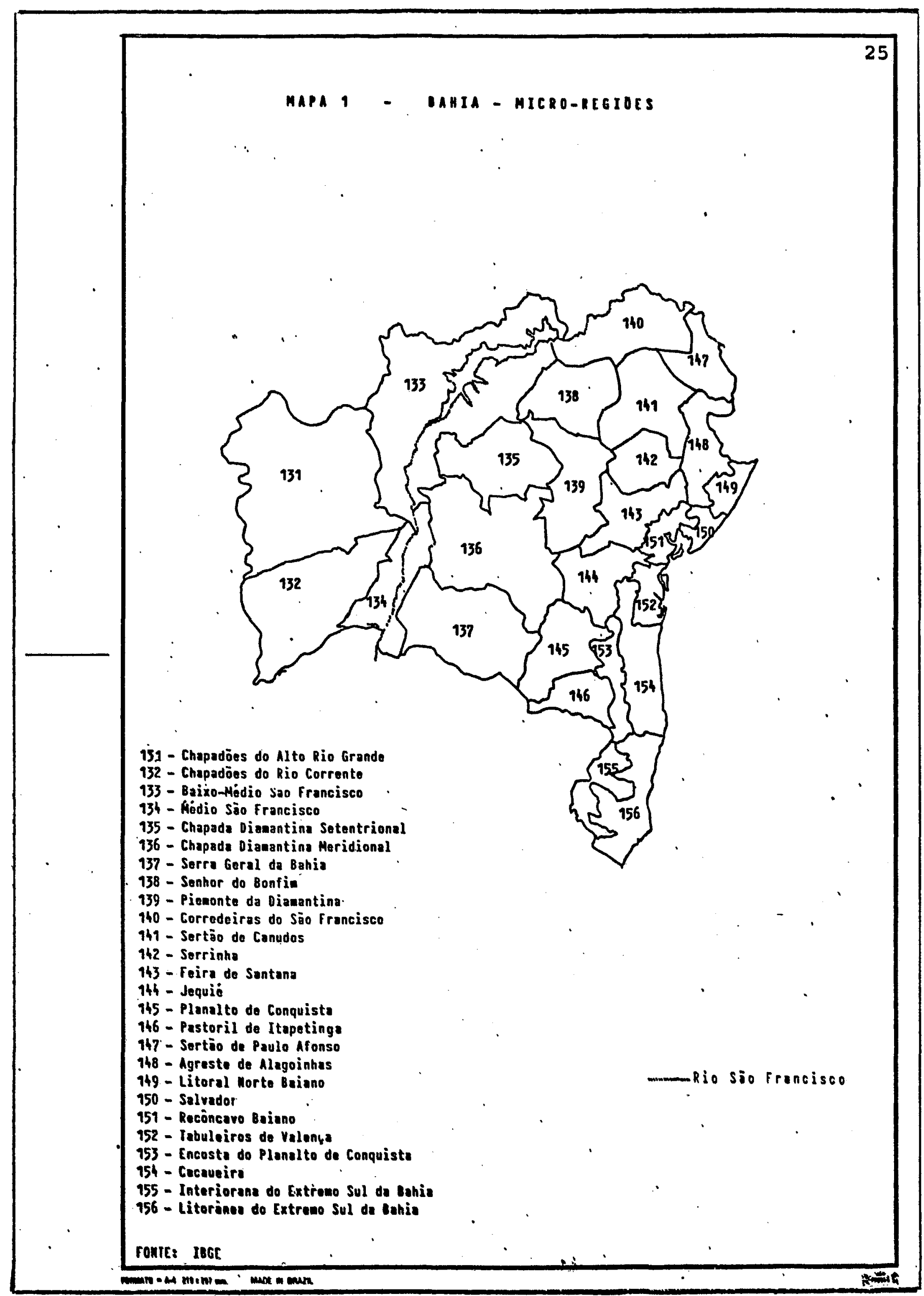


capital. Em função disso, optou-se por excluir esta microrregião da análise.

Os dados do Censo Agropecuário de 1980 permitiram a construção de 18 indicadores de modernização a nível de micrroregião, dando origem à matriz M. Devido ao grande número de indicadores utilizou-se um método estatístico de Análise Multivariada (Análise de Componentes), extraindo-se três fatores (componentes principais) que refletem as informações dos indicadores originais.

A aplicação deste método deu origem a duas matrizes: F e A. A matriz A é constituída de 18 linhas e 3 colunas. Os elementos dessa matriz são os coeficientes de correlação entre cada uma das 18 variáveis indicadoras de modernização e cada um dos 3 fatores extraidos. Essa matriz serviu para interpretar o significado de cada um dos fatores em termos das variáveis originais, cobrindo diversos aspectos de modernização da agricultura (intensidade do uso da terra, produtividade do trabalho, escala de produção etc.).

A matriz F, formada por 25 linhas correspondentes a cada microrregião homogênea (MRH) do estado da Ba hia (excluindo salvador), e 3 colunas representativas de cada fator de modernização, foi utilizada nas análises de regressão. Além disso, os valores dos fatores permitiram agrupar as microrregiōes homogêneas de acordo com as principais características da modernização da sua atividade agropecuária. 
As Tabulações Especiais sobre Renda para 1980 permitiram construir 5 medidas descritivas de características básicas da distribuição de renda: renda média, Índice de Gini, índice de pobreza de sen, porcentagem de pobres e fração da renda apropriada pelos dez por cento mais ricos.

Estas medidas estão representadas no nosso esquema metodológico como vetores, cada um com 25 elementos correspondentes às microrregiões do estado da Bahia. Estes vetores, denotados por V1, V2, V3, V4 e V5, correspondem às variáveis dependentes das equações de regressão linear múltipla.

Por último, realizaram-se regressões múltiplas ponderadas entre cada um dos vetores mencionados acima e a matriz $\mathbf{F}$ dos fatores de modernização. Os resultados permitiram analisar a relação existente entre cada um dos aspectos da distribuição de renda e as características da modernização a nível das 25 microrregiões homogêneas do estado da Bahia em 1980.

o estudo das relações entre modernização e distribuição de renda na agricultura do estado da Bahia faz parte de um programa de pesquisa mais amplo que, sob a orientação do professor Rodolfo Hoffmann, inclui também os estados de Paraná, Mato Grosso do Sul, Mato Grosso, Rio Grande do sul e são Paulo. 
Entre os estados do Nordeste, o da Bahia é o mais extenso e populoso. O Censo Demográfico de 1980 registrou 9,4 milhões de habitantes neste estado, sendo que 4,8 milhões $(50,7 \%)$ viviam em zonas rurais. Por outro lado, a Bahia foi um dos estados do Nordeste que mais modernizou sua agricultura na década de 70. Este progresso, ao atingir apenas certas áreas e produtos, contribuiu para acentuar a heterogeneidade espacial do estado em termos do grau de modernização. O exame dessas diferenças ao nível das microrregiões homogêneas e sua associação com as características da distribuição de renda constitui um estudo de caso privilegiado para a análise da relação entre modernização e distribuição de renda.

A seguir são detalhadas as fases básicas da metodologia seguida. 


\subsection{Escolha dos Indicadores de Modernização}

Antes de entrar na escolha dos indicadores de modernização é bom esclarecer o que se está entendendo por tal processo. Com base em KAGEYAMA (coord.) (1987), e sem a intenção de entrar nos conceitos teóricos, podemos dizer que modernização é uma transformação que ocorre na agricultura durante um longo período. Numa fase inicial, a própria agricultura elaborava tudo o de que precisava, quanto a insumos e equipamentos, bem como garantia a reprodução da própria força de trabalho utilizada. Tratava-se de uma agricultura extensiva, que crescia com base no aumento das áreas cultivadas e só tinha relação com o mercado (principalmente o mercado externo) pela venda do seu produto principal.

Com o processo de desenvolvimento, essa agricultura "natural". foi-se modificando e as atividades agrícolas se integraram à indústria, passando crescentemente a comprar insumos e equipamentos, além de ter-se ampliado o processamento industrial de produtos agrícolas. Ocorre uma intensificação da divisão social do trabalho. os estabelecimentos agrícolas deixam de elaborar seus insumos e equipamentos, diminuem a produção de subsistência dos trabalhadores e passam a comprar da indústria ou de outros estabelecimentos agrícolas que se dedicam à produção co- 
mercial de alimentos. Simultaneamente, amplia-se o uso do trabalho assalariado. o salário é pago em dinheiro, o que possibilita por parte do trabalhador a compra dos produtos de que necessita de fora da própria fazenda onde trabalha, ampliando deste modo o mercado interno de alimentos ou de bens de consumo em geral.

o uso da terra passa a ser intensivo, ou seja, passa a depender menos da própria quantidade da terra e a elevar seu rendimento com a ajuda dos insumos e equipamentos comprados da indústria. A agricultura passa cada vez menos a depender da Natureza, ou seja, das condições naturais dadas, passando a "fabricá-las" sempre que for necessário.

Resumindo, o processo de modernização da agricultura envolve a substituição da agricultura natural por atividades agrícolas integradas à indústria, a intensificação da divisão social do trabalho e das trocas intersetoriais, ao mesmo tempo em que a atividade agrícola dá um salto tecnológico que possibilita aumentos de produtividade bem mais próximos aos verificados na indústria.

Sendo então um processo complexo e com múltiplos aspectos, torna-se impossivel "medir" a modernização por um só tipo de variável simples. Em função disso, costuma-se quantificar o grau de modernização da agricultura a partir de uma combinação de variáveis. 
A escolha dos indicadores de modernização teve como ponto de partida os trabalhos de HOFFMANN e KAGEYAMA (1985) e HOFFMANN et alii (1985).

Com os dados do Censo Agropecuário de 1980 foram construidas 18 variáveis indicadoras do grau de modernização a nível de microrregião que podem ser resumidas nos 5 grupos seguintes:

a) variáveis relacionadas com a intensidade de exploração da terra (9)

ATTO:

área trabalhada (área com culturas, pastagens plantadas e matas plantadas) em relação à área total dos estabelecimentos $(8)$

DTAE :

valor total das despesas por hectare de área explorada (área trabalhada + área com pastos e matas naturais) em Cr\$/ha

TRAT:

número de tratores por 1000 hectares de área trabalhada

VBTO: valor dos bens existentes nos estabelecimentos agropecuários (prédios, instalações 
e benfeitorias, culturas permanentes, matas plantadas, animais de criação e trabalho, máquinas e instrumentos agrários, veículos e outros meios de transporte) por hectare de área total (Cr\$/ha)

VPAE:

valor da produção total agropecuária por hectare de área explorada ( $\mathrm{Cr} \$ / \mathrm{ha}$ )

BOPA: número de bovinos por hectare de área total de pastagens

AOTE: número de estabelecimentos que utilizam adubação orgânica em relação ao número total de estabelecimentos ( $(8)$

AQTE: número de estabelecimentos que utilizam adubação química em relação ao número total de estabelecimentos ( 8 )

AIAT: área irrigada em relação à área trabalhada $(8)$ 
b) variáveis relacionadas com a produtividade do trabalho (3)

iviEH: número de tratores por 1000 equivalenteg- homem ocupados (ver Anexo 1) nos estabelecimentos

VBEH:

valor dos bens (vide definição de VBTO) por equivalente-homem $\quad(\mathrm{Cr} \$ / \mathrm{EH})$

VPEH: valor da produção total agropecuária por equivalente-homem ( Cr\$/EH)

c) variáveis relacionadas com o uso do trabalho assalariado (2)

MTEH :

emprego temporário (inclusive empreitadas) em relação ao total de equivalentes-homem ocupados $\left(\frac{8}{8}\right)$

EMEH : empregos de assalariados (permanentes e temporários, inclusive empreitadas) em relação ao total de equivalentes-homem ocupados $(q)$

\section{d) variáveis relacionadas com financiamen- tos (2)}


CGTC: valor dos financiamentos obtidos de fontes governamentais em relação ao valor total dos financiamentos ( $(z)$

FIAE: valor total dos financiamentos recebidos por hectare de área explorada. (Cr\$/ha)
e) variáveis relacionadas com a escala do empreendimento (2)

VPES: $\quad$ valor da produção agropecuária por estabelecimento (Cr\$)

VBES: valor dos bens (vide definição de VBTO) por estabelecimento (Crs)

As 18 variáveis indicadoras de modernização a nivel de microrregião acima descritas deram origem a uma matriz formada por 25 linhas e 18 colunas onde as 1inhas correspondem às microrregiões e as colunas às variáveis indicadoras de modernização. No esquema metodológico esta matriz é denotada pela letra $\mathbf{M}$.

A tabela 1 a seguir mostra as médias e coeficientes de variação destes indicadores de modernização.

A percentagem da área irrigada sobre área trabalhada (AIAT) apresenta uma média das microrregiões 


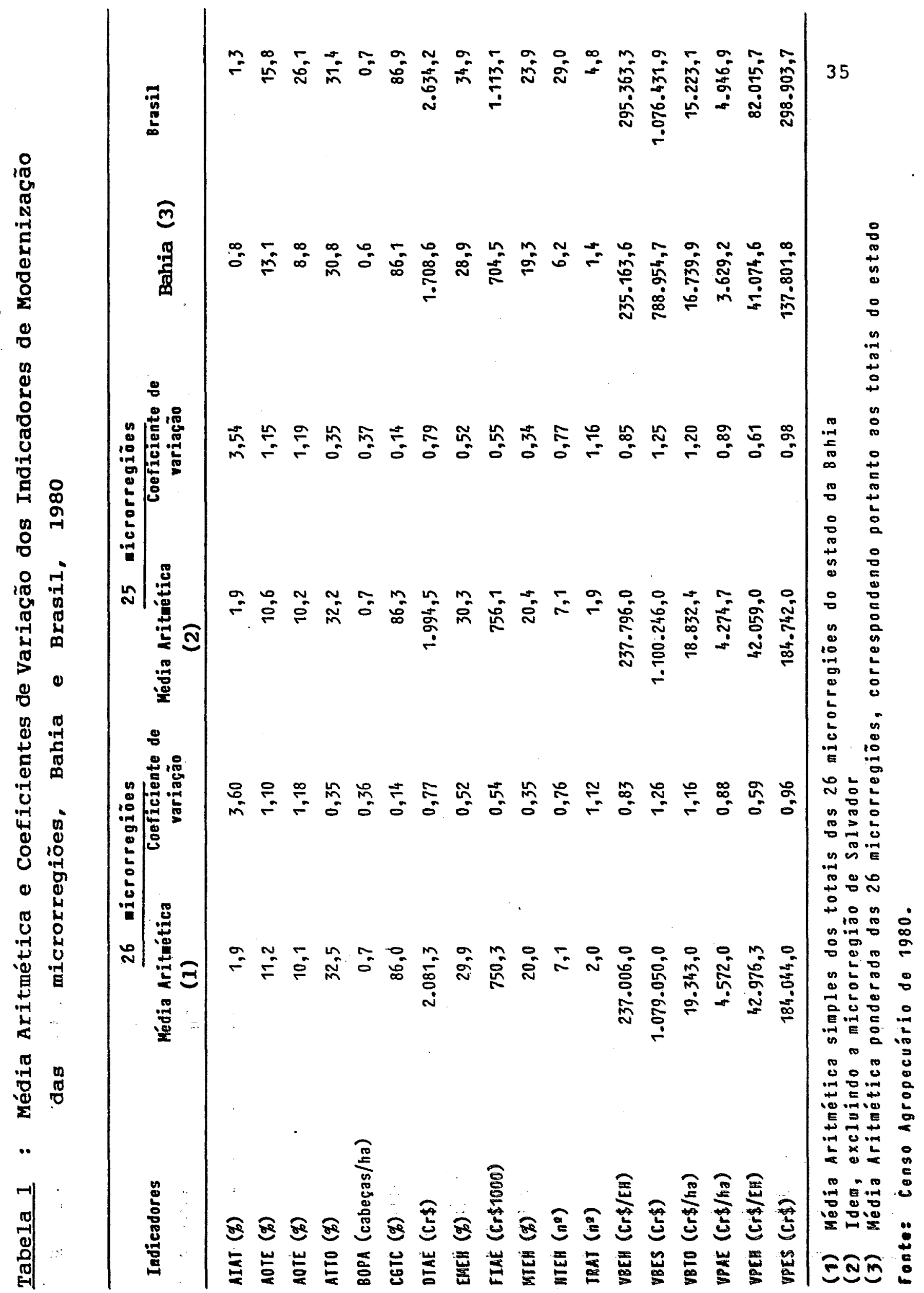


(não ponderada) bem maior que o valor da variável no estado e para o Brasil e é dentre todas as variáveis a que apresenta a maior dispersão relativa, com um coeficiente de variação de 3,5, isto é, seu desvio-padrão é 3,5 vezes maior do que a média. Isto se deve à microrregião corredeiras do são Francisco que tem 348 de área irrigada, sendo no estado da Bahia a segunda microrregião em termos de área irrigada absoluta (ver Tabela A2.1 no Anexo 2). Entretanto, trata-se da microrregião que tem a menor área trabalhada. Nela, a agricultura é escassa e a pouca que existe deve-se ao fato de estar localizada perto do rio são Francisco, que possibilita sua irrigação.

Entretanto, cabe destacar a produção das lavouras temporárias de cebola e feijão, com $36 \%$ e $37 \%$, respectivamente, do valor da produção e com um alto valor comercial. A produção de cebola e feijão desta microrregião explica também a variável número de tratores por 1000 hectares de área trabalhada. (TRAT), com uma médja maior que - valor da variável no estado, porém menor do que o valor para o Brasil. o coeficiente de variação também é alto, maior que a unidade. E também na microrregião corredeiras do são Francisco que a variável TRAT apresenta seu mais alto valor, mais do dobro do segundo lugar mais alto, apresentado pela microrregião Chapada Diamantina setentriona1. Isto deve-se principalmente ao grande número de 
tratores, inclusive tratores pesados ${ }^{1}$, que são usados na preparação da terra para a plantação da cebola.

o valor dos bens existentes nos estabelecimentos agropecuários por hectare de área total (VBTO) e valor dos bens por estabelecimento (VBES) apresentam médias superiores aos valores para a Bahia e para o Brasil. o coeficiente de variação também é alto, maior que a unidade. o principal responsável por isto é a microrregião Cacaueira, que detém o maior valor dos bens, mais de 5 vezes o segundo maior valor do estado, que é o da microrregião Encosta do Planalto da Conquista, também produtora de cacau.

A porcentagem do número de estabelecimentos que usam adubação química em relação ao número total de estabelecimentos (AQTE) apresenta uma média maior do que o valor da variável no estado, ainda que menor que o valor para o país, e um coeficiente de variação maior que a unidade, também principalmente devidó à microrregião Cacaueira, que é a que utiliza mais adubos químicos comparativamente às outras regiões.

Por último, entre as variáveis que apresentam um coeficiente de variação alto (maior que a unidade) temos a porcentagem do número de estabelecimentos que usam

1 Dos 362 tratores usados nessa microrregião, 183 eram de mais de $100 \mathrm{cv}$ em 1980 . 
adubação orgânica em relação ao número total de estabelecimentos (AOTE), com uma média um pouco menor do que o valor para o Brasil. Nota-se que o uso de adubos orgânicos é alto em metade das microrregiões do estado, devendo-se a alta dispersão principalmente às microrregiōes do Recôncavo Baiano e Feira de Santana.

Com um coeficiente de variação entre 0,5 e 1, e média menor do que o valor para o Brasil, podemos citar as variáveis valor total das despesas por hectare de área explorada (DTAE), porcentagem do emprego assalariado em relação ao total de equivalentes-homem ocupados (EMEH). valor dos bens por equivalente-homem (VBEH), valor da prođução total agropecuária por hectare de área explorada (VPAE), valor total da produção agropecuária por equivalente-homem (VPEH) e valor da produção agropecuária por estabelecimento (VPES). A microrregião Cacaueira é talvez a única responsável pela elevada dispersão, já que esta microrregião detém os mais altos valores tanto dos bens existentes nos estabelecimentos agropecuários (o que afeta a variável VBEH), quanto da produção total agropecuária (que afeta as variáveis VPAE, VPEH e VPES), do total das despesas (que afeta a variável DTAE) e ainaa o maior número de empregados permanentes, temporários e por empreitada em equivalentes-homem (que influe na variável EMEH) . 
As microrregiões Litorânea do Extremo sul da Bahia e Chapada Diamantina setentrional são as que apresentam os dois mais altos valores da variável número de tratores por 1000 equivalentes-homem nos estabolecimentos (NTEH). Ambas as microrregiões têm produção de feijão e milho, culturas que nas condições de produção destas microrregiões explicariam o alto uso do trator. Iembramos que na microrregião Chapada Diamantina setentrional está o município de Irecê, já conhecido pela produção de feijão em condições modernas.

Os demais indicadores de modernização apresentam dispersão relativamente pequena e médias semeIhantes às do estado e do país.

Queremos também aqui ressaltar o fato de que a exclusão da microrregião de salvador não afeta este estudo em termos de médias e dispersão das variáveis indicadoras de modernização.

Com o objetivo de entender a relação existente entre os indicadores de modernização acima caracterizados em função de suas médias e coeficientes de variação, analisaremos sumariamente os coeficientes de correlação entre estes indicadores (Ver Tabela 2).

As variáveis que poderiam teoricamente caracterizar a intensidade de exploração da terra o que têm um sentido intuitivamente claro, são a proporção da área 


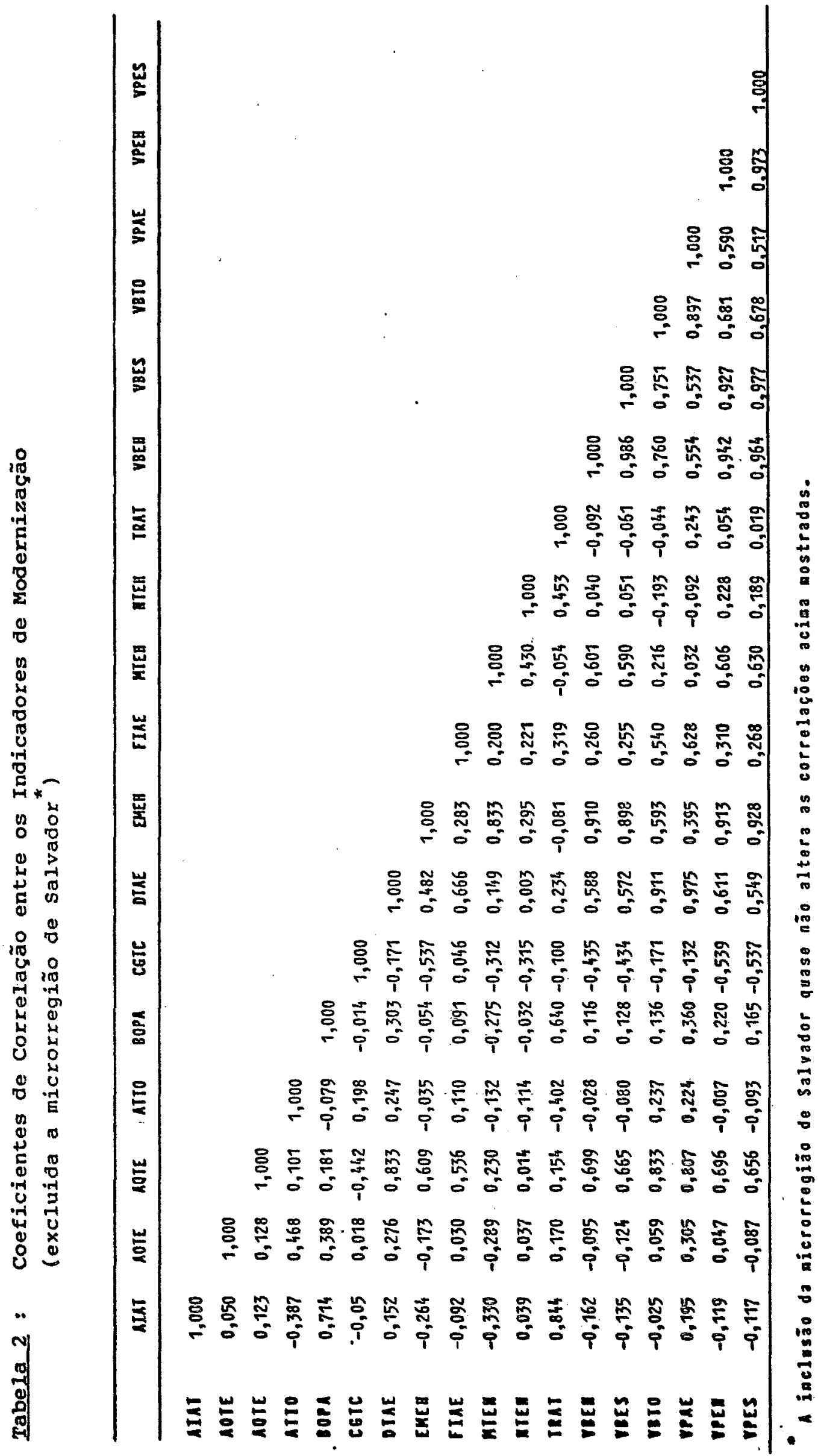


total efetivamente trabalhada (ATTO) e valor total das despesas por hectare de área explorada (DTAE). Mas estas variáveis estão expressando sentidos diferentes de intensidade de exploração da terra: a primeira indica se o estabelecimento está trabalhando ou não uma grande proporção da área total de que dispõe; a segunda, indica a intensidade de aplicação de insumos e capital por unidade de área efetivamente cultivada.

Pode ocorrer perfeitamente que um estabelecimento explore intensivamente a terra num destes sentidos e não no outro. Por exemplo, um estabelecimento usa uma grande parte da área total de que dispõe, mas o faz com atividades agropecuárias que não envolvem uma grande despesa por área efetivamente explorada, ou vice-versa. É o que parece ocorrer ao nível das microrregiões homogêneas do estado da Bahia. De fato, o coeficiente de correlação entre DTAE e ATTO, embora positivo, não é significativamente diferente de zero.

Outra variável teoricamente relacionada com a intensidade de exploração da terra no segundo sentido anteriormente citado é o número de tratores por 1000 hectares de áréa trabalhada (TRAT), ou seja, deixando de lado as diferenças que possam existir entre um trator e outro, quanto maior o número de tratores por área trabalhada maior o grau de intensidade de exploração da terra trabalhada. Pela mesma razão anterior, é possí- 
vel que um estabelecimento utilize uma proporção grande de sua área total e ao mesmo tempo o tipo de atividade agropecuária que realiza não implica em uso de um número muito grande de tratores por área trabalhada. Isto também parece ocorrer ao nível das microrregioẽs homogêneas do estado da Bahia. Neste caso, observa-se uma correlação negativa e significativa entre ATTO e TRAT.

Assim por exemplo, na microrregião de Corredeiras do são Francisco, a proporção efetivamente trabaIhada da área total dos estabelecimentos é uma das menores entre todas as microrregiões da Bahia $(12,48)$, enquanto que esta é a microrregião que tem o maior número de tratores por área efetivamente trabalhada (11 tratores por 1000 ha). o exemplo contrário é o da microrregião Feira de Santana que, junto com Agreste de Alagoinhas, tem a maior proporção de área total efetivamente trabalhada (cerca de 55\%) e não tem um número elevado de tratores por área trabalhada $(0,8 \text { tratores por } 1000 \text { ha de área trabalhada })^{1}$.

A variável valor dos bens existentes nos estabelecimentos agropecuários por hectare de área total (VBTO) expressa indistintamente os dois sentidos anteriormente mencionados que podem envolver o termo intensidade de exploração da terra. Poderiamos esperar que quanto maior

1

1 o valor total das despesas por hectare de área explorada tampouco está correlacionada com TRAT. o coeficiente de correlação, embora positivo, não é significativo ao nível de $5 \%$. 
- valor dos bens por área total do imóvel mais intensivamente esse estabelecimento explora a terra, seja porque ele trabalha uma proporção maior da área total do estabelecimento, seja porque suas atividades agropecuárias na área trabalhada envolvem bens de alto valor.

Para as microrregiões do estado da Bahia, a correlação entre ATTO e VBTO é positiva, porém não-significativa. Portanto, as microrregiões que tem um elevado valor total de bens por área total não necessariamente trabalham uma proporção elevada de sua área total. Nessas microrregiões em que os estabelecimentos usam intensivamente a terra no sentido de terem um alto valor de bens por área total, o que geralmente ocorre é que o tipo de atividade agropecuária que realizam implica uma exploração intensiva da terra efetivamente trabalhada.

Para as microrregiões da Bahia, VBTO está positivamente correlacionada com DTAE, mas não com TRAT ${ }^{l}$. Então, o uso mais intensivo da terra efetivamente trabalhada implica maiores despesas por área explorada mas não necessariamente um maior número de tratores por área trabaIhada, pois o valor dos bens inclui muitas outras variáveis além de tratores. Por exemplo, inclui o valor das culturas permanentes, nas quais geralmente é menor a utilização de tratores.

I o coeficiente de correlação entre VBTo e DTAE é positivo e significativo a 58, enguanto o coeficiente de correlaçào entre VBTo e TRAT é negativo porém não-significativo. 
O valor da produção total agropecuária por hectare de área explorada (VPAE) é também uma variável relacionada com a intensidade de uso da terra. Entretanto, ao contrário do valor dos bens por área total e das despesas totais por área explorada, é mais um resultado da intensidade do uso da terra do que um fator determinante da maior intensidade do uso da terra. Para as microrregiões do estado da Bahia, essa variável (VPAE) está significativamente correlacionada com VBTO e DTAE, mas não com ATTO e TRAT.

As outras variáveis associadas hipoteticamente à intensidade de exploração da terra - número de bovinos por hectare de área total de pastagens (BOPA), número de estabelecimentos que usam adubação orgânica em relação ao total de estabelecimentos (AOTE) e área irrigada em relação à área trabalhada (AIAT) - não têm correlação significativa com as três variáveis antes indicadas (DTAE, VPAE, VBTO). No caso dos adubos químicos, as principais microrregiões em termos da produção agropecuária na Bahia têm uma alta proporção de estabelecimentos que usam adubos químicos, notadamente aquelas em que se destacam as lavouras permanentes, especialmente cacau e café.

As duas variáveis que teoricamente expressam a escala de empreendimento são valor da produção agropecuária por estabelecimento (VPES) e valor dos bens por estabelecimento. (VBES). Estas duas variáveis estão forte- 
mente correlacionadas entre si. Já vimos que a intensidade de uso da terra na Bahia está mais vinculada ao valor dos bens por área explorada que propriamente à proporção da área total que é efetivamente trabalhada. Desse ponto de vista, o valor dos bens por estabelecimento parece expressar melhor o fator escala do empreendimento de um ponto de vista econômico. o valor da produção por estabelecimento, variável associada ao valor dos bens por estabelecimento é. na verdade, mais bem um resultado que um fator da escala de empreendimento.

o valor dos bens, conforme se definiu anteriormente, é um agregado de elementos bastante diferenciados, que inclui desde prédios residenciais (pouco ou nada relacionados com a "modernização") ou animais de criação e trabalho (também não necessariamente representativos de atividade moderna), até os tratores e equipamentos (típicos representantes do gue se chama convencionalmente de agricultura moderna).

Em termos teóricos, o valor dos bens deveria ser visto como uma "proxy" do capital fixo, assim como as despesas são uma "proxy" do capital circulante empregado na produção.

ocorre, porém, que a composição do valor dos bens pode ser muito variável. Por exemplo, na região Cacaueira o principal componente do valor dos bens são as lavouras permanentes ( 488 do total), enquanto no municipio 
de Irecê da microrregião Chapada Diamantina Setentrional as máquinas e instrumentos agrários representam $10 \%$ do vaIor dos bens.

Quando se analisam microrregiões com certa especialização produtiva, conforme apontado anteriormente, pode ocorrer que o valor dos bens, em vez de representar um capital fixo genérico (que é o que deve ocorrer a nível do Brasil como um todo), reflita um tipo particular de capital fixo (como as lavouras permanentes ou os animais ou as máquinas). Em função disso, nem sempre os coeficientes de correlação irão indicar a relação teoricamente esperada.

Isso ajuda a explicar, por exemplo, o sinal negativo da correlação entre o indicador VBEs e os indicadores AIAT (irrigação), CGTC (crédito governamental) e TRAT (uso de tratores), o que não seria esperado teoricamente. o mesmo tipo de problema surge com VBEH (vaIor dos bens por equivalente-homem), que não se apresenta correlacionado com NTEH, ao contrário do que seria esperado, mas tem, por exemplo, correlação positiva, ainda que baixa, com BOPA (bovinos por hectare de pastagens) e negativa (mas bastante baixa) com TRAT.

Das três variáveis que teoricamente se relacionam com a capacidade produtiva da força de trabalho número de tratores por equivalente-homem. ocupado nos 
estabelecimentos (NTEH), valor dos bens por equivalente-homem (VBEH) e valor da produção total agropecuária por equivalente-homem (VPEH) - NTEH não está correlacionada com VBEH e apenas fracamente associada com VPEH. E como se a produtividade do trabalho (tendo como "proxy" o VPEH) nas microrregiões da Bahia fosse muito menos dependente da mecanização (NTEH) do que de outros fatores mais gerais associados à atividade agrícola. Entre esses destacam-se a intensidade de exploração da terra e, sobretudo, o volume de capital fixo. o coeficiente de correlação entre VPEH ("produtividade") e VBEH (relação "capital-fixo-trabaIho") é bastante elevado $(0,94)$, ao contrário do que ocorre entre VPEH e NTEH.

As duas variáveis que teoricamente expressam o uso do trabalho assalariado - emprego temporário em relação ao total de equivalentes-homem ocupados (NTEH) e emprego assalariado em relação ao total de equivalentes-homem ocupados (EMEH) - estão positivamente correlacionados. Ou seja, nas microrregiōes em que é maior a proporção de equivalentes-homem que corresponde ao trabalho assalariado, é também maior a proporção de empregados temporários. Em resumo, onde pesa o emprego assalariado pesa também o emprego temporário.

E por último, as duas variáveis que teoricamente expressam o uso de financiamentos não estão correlacionadas. o coeficiente de correlação, embora positivo. 
não é significativo, vale dizer, as microrregiões em que o valor total dos financiamentos recebidos por hectare de área explorada é elevado não necessariamente têm uma elevada proporção dos mesmos que são obtidos de fontes governamentais.

Note que CGTC é uma proporção e FIAE é um volume monetário por hectare. Pode ocorrer, por exemplo, que numa região onde predominam os créditos de particulares (CGTC baixo) haja uma presença maior de grandes propriedades que se apropriam do crédito governamental, fazendo em média com que FIAE seja alto. De toda forma, a não associação, entre FIAE e CGTC não autoriza concluir que o crédito governamental não tenha contribuido para elevar o valor dos financiamentos por hectare explorado. A falta de correlação, no caso, deve-se mais à pequena dispersão de CGTC (coeficiente de variação $=0,14$ ), que variou entre um mínimo de 53,3\% e um máximo de $99,4 \%$. 


\subsection{Indicadores de Distribuição de Renda}

Com as informações de renda a nivel de microrregião obtidas das Tabulações Especiais sobre Renda para 1980, foram calculadas 5 medidas descritivas sobre distribuição de renda: renda média, índice de Gini, proporção de pobres, índice de sen e participação na renda global dos $10 \%$ mais ricos da população, dando origem aos vetores V1, V2, V3, V4 e V5 respectivamente. Os vetores tem 25 elementos, cada elemento correspondendo a uma microrregião (excluido, salvador). Estes vetores foram utilizados como variáveis dependentes nas 5 equações de regressão múltipla.

Na construção destas medidas se consideram as pessoas economicamente ativas (PEA) na agropecuária, extração vegetal e pesca de acordo com o Censo Demográfico de $1980^{l}$, que tiveram rendimentos não nulos.

I Existia a possibilidade de em vez de considerar as pessoas economicamente ativas (PEA) na agropecuária, considerar a renda per capita da familia cujo chefe trabalha na agricultura, Descartou-se esta última por dois motivos: 10) a renda per capita da família é um valor que é afetado pelo número de pessoas na família. A média de pessoas na.familia é diferente de uma regiāo para outra e portanto a renda per capita familiar também é diferente entre as regiōes, o gue não tem a ver rigorosamente com as características da agricultura da região, e

20) Pode ocorrer que membros da familia cujo chefe trabaIha na agricultura, não trabalhem nesta atividade; neste caso, sua contribuição para a renda familiar năo depende das características da agricultura da região. Assim . 0 enfoque ( continua...) 
As tabulações especiais do Censo Demográfico de 1980 informaram, para cada microrregião do estado da Bahia, o número de pessoas em 10 estratos de rendimentos ${ }^{1}$.

Utilizamos a Renda Média para expressar $\cdot a$ tendência central da distribuição de renda. 0 indice de Gini é uma medida de desigualdade desta distribuição. No cálculo do índice de Gini a curva de Pareto com 2 parâmetros foi utilizada para estimar a desigualdade dentro do estrato de nível de renda mais alto, quando este era aberto à direita. Para os outros estratos, com limites finitos, se adotou a hipótese de que a distribuição dentro do estrato tem função de densidade linear ${ }^{2}$. Outro indicador de desigualdade utilizado, foi a participação na renda global dos $10 \%$ mais ricos da população economicamente ativa. $(10+)$.

agui adotado privilegia o ponto de vista da capacidade da agricultura como fonte de renda para as pessoas que nela trabalham. Isso tem, em contrapartida, o defeito de não poder captar as condições efetivas em que vivem esses trabalhadores (e empregadores), mesmo em termos da renda, porque não considera as redistribuições intra-famílias. 1 Utilizando como unidade de medida o valor do maior salário mínimo vigente no país em agosto de 1980 , os 10 estratos de rendimento são os seguintes: até 0,25 ; mais de 0,25 a 0,5 , mais de 0,5 a 1 , mais de 1 a 1,5, mais de 1,5 a 2, mais de 2 a 3 , mais de 3 a 5 , mais de 5 a 10 , mais de 10 a 20, e mais de 20 salários mínimos. Para a análise foram fixadas as rendas médias para cada estrato que são as seguintes: 0,$16 ; 0,41 ; 0,80 ; 1,25 ; 1,75 ; 2,50 ; 3,80 ; 7,00$; 14,$00 ;$ e 40,00 .

I Para maiores esclarecimẹtos ver HOFFMANN (1979). 
Um dos indicadores de pobreza utilizado foi a proporção de pessoas ativas com renda monetária inferior a meio salário mínimo. Ou seja, adotamos a linha de pobreza de 0,5 salário mínimo e consideramos a proporção de pobres como medida de pobreza.

Outra medida de pobreza usada foi o indice de Sen. Este considera não somente a proporção de pessoas pobres da população mas também a intensidade relativa media dessa pobreza, expressada pelo quanto haveria que proporcionar ao conjunto de pobres para levá-los à linha de pobreza, e o grau de desigualdade de renda entre os pobres ${ }^{1}$.

Dos estados do Nordeste, o da Bahia é o que tem maior nível médio e maior desigualdade de renda no que se refere à população economicamente ativa da agricultura, extração vegetal e pesca em 1980 (Ver Tabela A2.2, Anexo 2). De fato, a renda média da PEA agrícola na Bahia é a única, dos estados do Nordeste claramente superior ao maior sa-

1 Se denotamos o índiçe de sen pela letra $P$, temos:

$\mathrm{P}=\mathrm{H}\left[\mathrm{I}+(1-I) \mathrm{G}^{*}\right]$ de sen pela letra $\mathrm{P}$, temos:

G*: é o índice de Gini da desigualdade da distribuição de renda entre os pobres.

H: proporção de pobres

I: insuficiência de renda

Por sua vez, $I=\frac{1}{k z} \sum_{i=1}^{k}\left(z-x_{i}\right), \quad 0 \leqslant I \leqslant 1$.

$k$ : número de individuos pobres

$z$ : linha de pobreza

$x_{i}$ : valores da renda de cada um dos pobres

Para mais detalhes ver HOFFMANN (1987). 
lário mínimo do país. Por outro lado, tanto o índice de Gini quanto a participação na renda global dos 10\% mais ricos na PEA agrícola são maiores na Bahia que nos outros estados do nordeste. A pobreza, pelo contrário, é um pouco menor no estado da Bahia, como indicam tanto a porcentagem de pobres quanto. o fndice de Pobreza de $\operatorname{sen}^{1}$.

Não obstante, comparativamente à média do país e especialmente aos principais estados (são Paulo, Paraná, Rio Grande do Sul, Mato Grosso e Mato Grosso do Sul) no que diz respeito à produção agropecuária, o nível e desigualdade de renda são menores na Bahia, ao mesmo tempo em que é maior a pobreza.

De modo que, embora gerando a maior renda média e a maior desigualdade de renda no Nordeste, a agricultura praticada no estado da Bahia está longe do observado nos estados mais importantes, do ponto de vista da produção agropecuária, no que se refere ao nível e desigualdade de renda.

1 Em HOFFMANN et alii (1985) considerou-se a linha de pobreza de I salário mínimo. Para um estudo a nivel nacional. que considera as diferenças entre os vários estados da federação, esta Iinha de pobreza se mostrou conveniente. Para o estudo específico de um estado do nordeste é mais adequada a utilização de uma linha de pobreza de 0,5 salários mínimo. Também aqui considerou-se o maior salário mínimo vigente no país (Cr\$4.149,60 em 1980), enguanto na Bahia o salário mínimo era de $\operatorname{Cr} \$ 3.436,80$ na mesma data. Com isto, a Iinha de pobreza adotada (Cr\$2.074,80) corresponde na verdade a $60,4 \%$ do salário mínimo vigente na Bahia em 1980. 
Entretanto, existem grandes diferenças entre as microrregiões da Bahia quanto à pobreza, 'nível e desigualdade de renda (Ver Tabela 3 ).

No que se refere à renda média das microrregiões, o desvio padrão equivale a $19,9 \%$ da média aritmética se excluido Salvador ${ }^{1}$. Os valores extremos são 0,86 salário mínimo em Sertão de Canudos e quase 1,6 salário mínimo em Chapada Diamantina Setentrional, ou seja, há quase $86 \%$ de diferença máxima de renda média entre as microrregiões.

- fndice de Gini tem um coeficiente de variação um pouco menor $(12,48)$. Os extremos são sertão de Canudos com 0,342 e Cacaueira com 0,535 , uma diferença de 56\%. As diferenças são um pouco maiores considerando como medida de desigualdade a participação na renda global dos $10 \%$ mais ricos da PEA agrícola. O coeficiente de variação é de 17,68 e a diferença máxima entre microrregiões é de $83,4 \%$, correspondendo às MRH já mencionadas. No éntanto,

I A inclusão da microrregião de salvador aumenta a média aritmética das rendas médias das microrregióes da Bahia e - aumento do coeficiente de variação é maior ainda.

o mesmo ocorre com o indice de Gini e com a participação na renda total dos $10 \%$ mais ricos da PEA agrícola. Ao contrário, a porcentagem de pobres $e$ o indice de pobreza de sen não são praticamente afetados pela inclusão da microrregião de Salvador, ou seja, esta microrregião se caracteriza por apresentar condiçóes de pobreza semelhantes às das demais microrregióes do estado, porém, com renda média e desigualdade muito, superior. Isto é compativel com nossa hipótese de que residem na microrregião de Salvador boa parte dos ricos ligados à agricultura de todo o estado da Bahia. 
Tabela 3 : Renda Média por Pessoa, indicadores de desigualdade e pobroza considerando a PEA na agropecuária em 1980, excluindo os que declararam renda nula nas microrregiōes do estado da Bahia, na Bahia e no Brasil.

\begin{tabular}{|c|c|c|c|c|c|}
\hline $\begin{array}{l}\text { Mica, arregizo Honogênea } \\
\text { (MRH) }\end{array}$ & $\begin{array}{l}\text { Renda média } \\
\text { em sal.mín.) }\end{array}$ & $\begin{array}{l}\text { Indice do } \\
\text { Gini }\end{array}$ & $10^{*}$ & $\begin{array}{l}\text { Porcantagon } \\
\text { do Pobres }\end{array}$ & $\begin{array}{l}\text { Indice do } \\
\text { Pobroze de }\end{array}$ \\
\hline 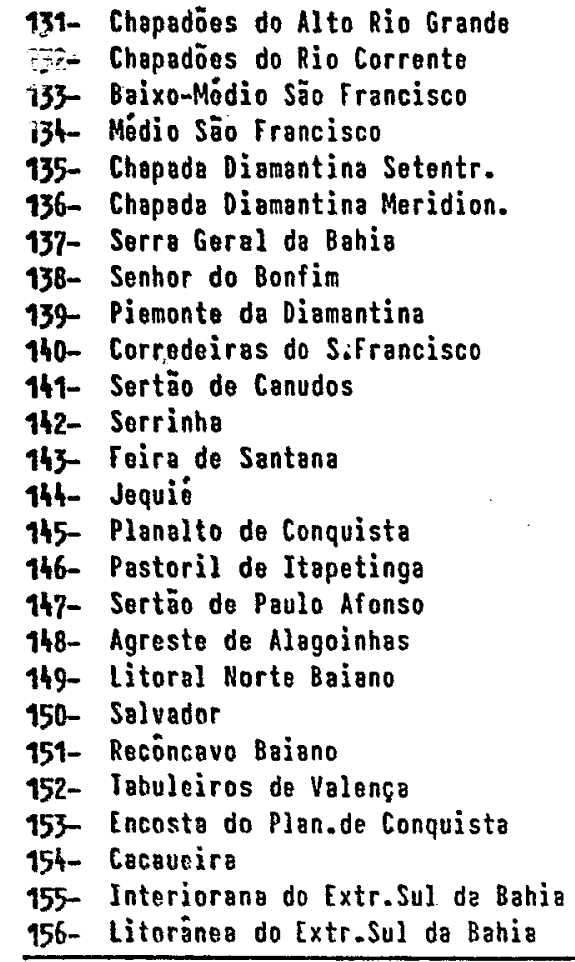 & $\begin{array}{l}1,083 \\
0,959 \\
1,073 \\
0,983 \\
1,597 \\
0,920 \\
0,948 \\
0,998 \\
1,083 \\
1,315 \\
0,860 \\
0,923 \\
1,046 \\
1,279 \\
1,252 \\
1,370 \\
0,900 \\
0,999 \\
1,059 \\
3,663 \\
1,052 \\
1,484 \\
1,213 \\
1,557 \\
1,416 \\
1,565 \\
\end{array}$ & $\begin{array}{l}0,491 \\
0,359 \\
0,428 \\
0,356 \\
0,443 \\
0,398 \\
0,379 \\
0,372 \\
0,393 \\
0,430 \\
0,342 \\
0,384 \\
0,437 \\
0,502 \\
0,483 \\
0,506 \\
0,362 \\
0,394 \\
0,429 \\
0,742 \\
0,425 \\
0,459 \\
0,444 \\
0,535 \\
0,481 \\
0,494\end{array}$ & $\begin{array}{l}34,09 \\
29,27 \\
33,63 \\
29,54 \\
37,94 \\
37,13 \\
30,27 \\
30,35 \\
33,39 \\
35,64 \\
27,59 \\
31,48 \\
37,21 \\
44,92 \\
43,99 \\
47,65 \\
29,99 \\
32,79 \\
37,97 \\
77,90 \\
35,07 \\
39,37 \\
49,73 \\
50,59 \\
43,14 \\
44,70 \\
\end{array}$ & $\begin{array}{l}25,4 \\
25,4 \\
29,1 \\
23,9 \\
11,1 \\
33,4 \\
29,2 \\
25,2 \\
21,6 \\
17,8 \\
29,6 \\
30,9 \\
29,3 \\
26,2 \\
23,4 \\
18,1 \\
30,1 \\
27,4 \\
26,1 \\
16,3 \\
28,8 \\
12,6 \\
16,9 \\
15,5 \\
17,0 \\
14,2 \\
\end{array}$ & $\begin{array}{l}0,110 \\
0,110 \\
0,146 \\
0,095 \\
0,041 \\
0,159 \\
0,131 \\
0,106 \\
0,090 \\
0,079 \\
0,129 \\
0,135 \\
0,130 \\
0,102 \\
0,084 \\
0,071 \\
0,118 \\
0,114 \\
0,102 \\
0,078 \\
0,128 \\
0,042 \\
0,060 \\
0,053 \\
0,069 \\
0,053 \\
\end{array}$ \\
\hline Média para 26 MRH & 1,254 & 0,438 & 37,90 & 23,3 & 0,098 \\
\hline $\begin{array}{l}\text { Coeficiente de variação para } \\
26 \mathrm{MRH}\end{array}$ & 0,431 & 0,185 & 0,247 & 0,275 & 0,336 \\
\hline $\begin{array}{l}\text { Média aritmética para } 25 \text { MRH } \\
\text { (excl. Salvador) }\end{array}$ & 1,157 & 0,426 & 36,54 & 23,5 & 0,098 \\
\hline $\begin{array}{l}\text { Coaficiente de variação para } \\
25 \text { MRH (exal. Salvador) }\end{array}$ & 0,199 & 0,124 & 0,176 & 0,279 & 0,338 \\
\hline Bahis & 1,196 & 0,460 & 40,31 & 23,9 & 0,101 \\
\hline Brasil & 1,596 & 0,546 & 47,80 & 22,2 & 0,101 \\
\hline
\end{tabular}

Fonte: Dados fornecidos por Rodolfo Hoffmann, calculados com baso om Tabulaçōes Especiais do Censo Demagráfico de 1980. 
os maiores valores das microrregiões da Bahia para a renda média, indice de Gini e participação dos $10 \%$ mais ricos da PEA apenas igualam as médias do conjunto do país.

Com relação aos indicadores de pobreza, a dispersão relativa é bem maior. No caso da porcentagem de pobres o coeficiente de variação é de $27,1 \%$ e a diferença máxima entre microrregiões é de 200\%, correspondendo às microrregiões Chapada Diamantina Setentrional e Meridional. No caso do índice de pobreza de sen o coeficiente de variação é maior ainda $(33,8 \%)$ e a diferença entre valores extremos corresponde às mesmas microrregiões e é de $288 \%$.

Concluímos desta análise que, no estado da Bahia, a média e a desigualdade de renda variam muito entre as microrregiões. Porém, varia mais ainda a pobreza da população economicamente ativa agrícola, principalmente guando consideramos não somente a proporção dos pobres do total, mas também a intensidade da pobreza e a desigualdade de renda entre os pobres.

Passemos agora a considerar as relações entre os indicadores dos vários aspectos da distribuição de renda (Ver Tabela 4).

Em geral, quanto maior o nivel de renda média da PEA agrícola de uma microrregião do estado da Bahia, maior a desigualdade de renda, medida tanto pelo indice de Gini quanto pela participação na renaa global dos 
Tabela 4 : Correlações de Pearson dos Indicadores de pobreza, nivel e desigualdade de renda da PEA na agropecuária em 1980. (a)

\begin{tabular}{|c|c|c|c|c|c|}
\hline & $\begin{array}{l}\text { Renda } \\
\text { Médi a }\end{array}$ & $\begin{array}{l}\text { Indice de } \\
\text { Gini }\end{array}$ & $\begin{array}{l}\text { 10\% mais } \\
\text { ricos }\end{array}$ & $\begin{array}{l}\text { Indice de } \\
\text { Sen }\end{array}$ & $\begin{array}{l}\text { Proporçao do } \\
\text { Pobres }\end{array}$ \\
\hline Renda Média & 1,000 & & & & \\
\hline Indice de Gini & 0,835 & 1,000 & & & \\
\hline $10 \%$ mais ricos & 0,827 & 0,979 & 1,000 & & \\
\hline Indice de Sen & $-0,874$ & $-0,595$ & $-0,672$ & 1,000 & \\
\hline \multicolumn{6}{|l|}{ Proporção de } \\
\hline Pobres & $-0,905$ & $-0,591$ & $-0,638$ & 0,686 & 9,000 \\
\hline
\end{tabular}

(a) Foram consideradas no cálculo das correlaçōes as 25 microrregiōes do estado da Bahia, oxcluida a microrregiào de Selvador.

Fonte: Tabulações Especiajs sobre renda para 1980 
108 mais ricos da PEA. Os coeficientes de correlação são positivos e significativos ${ }^{1}$. Pelo contrário, de um modo geral, quanto maior o nível de renda média, menor a pobreza medida tanto pela proporção dos pobres quanto pelo indice de pobreza de Sen. Os coeficientes de correlação são negativos e significativos.

De modo que, nas microrregiões do estado da Bahia, além de serem muito aiferentes os Indicadores de pobreza, nível e desigualdade de renda, eles estão correlacionados entre si.. Este trabalho tenta mostrar que são as peculiaridades das atividades agropecuárias praticadas nas diversas regiões que estão por trás dessa diversidade e correlação das variáveis que caracterizam a distribuição de renda da PEA agrícola das microrregiões.

Antes de entrar especificamente nesta matéria através das análises multivariada.e de regressão linear múltipla, objeto dos próximos itens, convém destacar que, apesar da diversidade de situações existentes nas microrregiōes, predominam no estado da Bahia níveis de ronda muito baixos.

Considerando o conjunto do estado, cerca de $24 \%$ da PEA agrícola estão abaixo da linha de pobreza ( 0,5 salário mínimo), sendo que, $5 \%$ sequer atingem metade deste valor. (Ver Tabela 5), Entretanto, isto não retrata

1 Estamọs considerando um nível de significância de 5\%. 


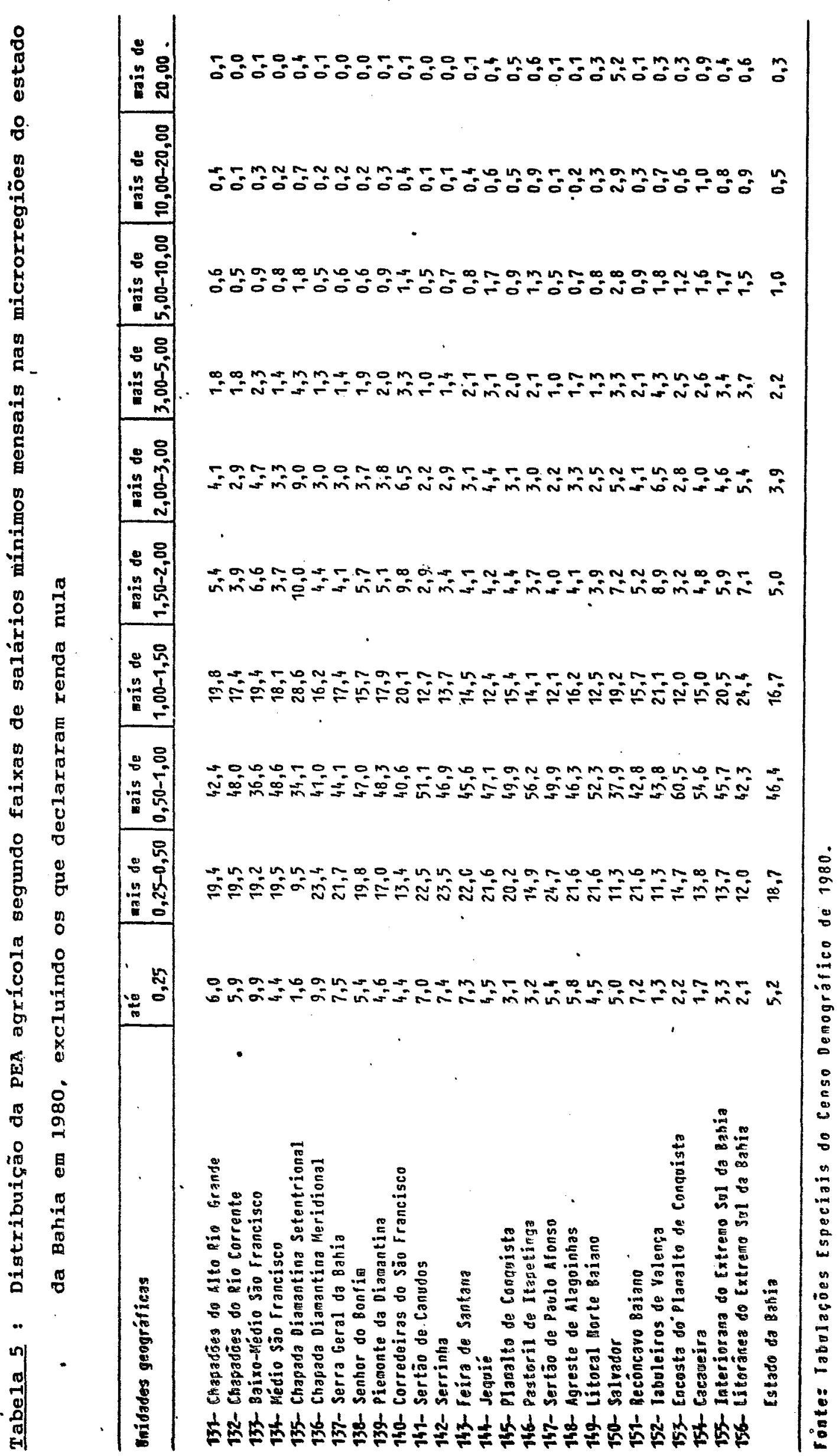


bem a situação de baixa renda de praticamente toda a PEA agrícola deste estado, pois outros $46 \%$ têm uma renda entre 0,5 e 1,0 salário mínimo, Ou seja, somente $30:$ da PEA agrícola da Bahia ganham mais que o salário mínimo, sendo que, 22\% estão na faixa de 1 a 2 salários mínimos. portanto, irrisórios 8\% da PEA agrícola auferem renda maior que 2 salários mínimos mensais.

As situações mais graves, entre as microrregiões do estado da Bahia, verificam-se nos sertões de Canudos e de Paulo Afonso, onde as proporções da PEA agricola ganhando mais de 2 salários mínimos não atingem $4 \%$. Nas microrregiões em que a agropecuária gera altos niveis de renda para uma proporção maior da PEA, esta não aumenta muito.

A microrregião com melhor situação neste aspecto é a Chapada Diamantina Setentrional (lavoura moderna e tecnificada - especialmente feijão), onde a proporção da PEA ganhando mais de 2 salários mínimos é de 168. Tudo indica que esta microrregião é a que apresenta no estado da Bahia as melhores condiçōes em termos de distribuição de renda. Nesta microrregião llo da PEA agricoIa estão abaixo da Iinha de pobreza e 558 ganham mais que I salário mínimo. Trata-se da única microrregião do estado onde mais da metade da PEA agrícola ganba acima de 1 sajario mínimo. A desigualdade de renda não é baixa, mas ẻ bastante inferior à de outras microrregiōes, como por exem- 
plo Jequié (região de gado-policultura), onde apesar de se praticar uma agricultura relativamente avançada é grande a proporção de pobres, ou em microrregiões como Pastoril de Itapetinga (gado melhorado) e Cacaueira (monocultura de cacau), pnde a proporção de pobres é bem menor mas a diferenciação de renda é muito acentuada. 


\subsection{Análise de Componentes Principais e Regressões Linea- res Múltiplas}

Como foi dito no item anterior, as diferenças de grau de pobreza, nível e desigualdade de renda da PEA agrícola entre microrregiões do estado da Bahia são relativamente grandes. Essas características da distribuição de renda estão correlacionadas entre si, de modo que, em geral, nas microrregiões onde o nível de renda é superior tendem a prevalecer menores graus de pobreza e maiores graus de desigualdade de renda da PEA vinculada à agropecuária.

Por outro lado, foi também dito que, são grandes as diferenças no tipo de produção agropecuária praticada em cada uma das microrregiões do estado da Bahia, diversidade que se traduz não só em produtos distintos mas também em valores diferentes de uma série de variáveis que medem a modernização, como intensidade de uso da terra, escala do empreendimento, produtividade do trabalho, tipo de relações de produção, etc.

\section{Pretendemos relacionar as características} da distribuição de renda da PEA agrícola com as peculiaridades da agropecuária praticada em cada uma das microrregiões do estado da Bahia tal como refletidas nas magnitudes daguelas variáveis. A primeira tarefa neste empre- 
endimento diz respeito ao encaminhamento do modo de expressar as peculiaridades da agropecuária das microrregiões de maneira a facilitar a análise de suas relações com as aracterísticas da distribuição de renda. A aplicação do :átodo dos Componentes Principais é um instrumento adequado para esse fim.

Uma alternativa seria relacionar diretamente, através de uma análise de regressão múltipla, cada uma das características da distribuição de renda com algumas das variáveis usadas para expressar as peculiaridades da produção agropecuária. Além da quantidade de observações (cada microrregião) limitar o número de variáveis independentes a serem incorporadas, certamente essa estratégia levaria a sérios problemas econométricos de multicolinearidade na estimação dos coeficientes da regressão, pois como indica a matriz de correlações entre as variáveis, muitas delas apresentam forte associação.

O método dos componentes principais proporciona uma forma de sintetizar grande parte das informacooses contidas nas variáveis que descrevem as peculiaridades da produção agropecuária das microrregiões do estado da Bahia, de modo que permite contornar os problemas de multicolinearidade na subsegüente análise de regressão múltipla entre as características da distribuição da renda e as peculiaridades da produção agropecuária. Trataremos de apresentar brevemente os procedimentos envolvidos nesta me- 
ologial.

O ponto de partida é a matriz $M$ dos indicadones de modernização (como já foi mencionado no item 3.1 ). Esta matriz contém os valores das 18 variáveis indicadoras de modernização para cada uma das 25 microrregiões do estado da Bahia (excluída Salvador). Indicando o número de variáveis por ng e o número de observações (microrregiões) por $\underline{N}$, a matriz $M$ pode ser representada da seguinte maneira:

$$
M=\left[\begin{array}{cccc}
M_{1,1} & M_{1,2} & \cdots & M_{1, N} \\
M_{2,1} & M_{2,2} & \cdots & M_{2, N} \\
\ldots & \ldots & \cdots & \ldots \\
M_{n, 1} & M_{n, 2} & \cdots & M_{n, N}
\end{array}\right]_{(n \times N)}
$$

o primeiro procedimento é transformar as variáveis. Seus valores originais se expressam em diferentes unidades de medidas (tratores por equivalente-homem ou por área explorada, valor da produção ou dos bens em cruzeiros por estabelecimento, etc.).

1 Na descrição desta metodologia usamos principalmente os trabalhos de CARVALHO (1982), e HOFFMANN et alii (1985). Para uma análise mais detalhada ver HARMAN(1976). 
A transformação é dada por:

$$
x_{i j}=\frac{M_{i j}-\bar{M}_{i}}{\sqrt{\sum_{j=1}^{N}\left(M_{i j}-\bar{M}_{i}\right)^{2}}}, \quad \text { onde }
$$

$\bar{M}_{i}=\frac{1}{N} \sum_{j=1}^{N} M_{i j} \quad$ é a média da i-ésima variável consideradas as $\mathrm{N}=25$ microrregiões.

Verifica-se que as variáveis transformadas têm média igual a zero e soma dos quadrados igual a 1. Deste modo transformamos a matriz original dos dados numa outra matriz $(\mathbf{X})$. Essas novas medidas das variáveis são números sem dimensão e dessa maneira não precisamos nos preocupar com o fato das variáveis originais terem unidades de medida diferentes.

A matriz $X$ com as variáveis transformadas pode ser representada da seguinte maneira:

$$
x=\left[\begin{array}{cccc}
x_{11} & x_{12} & \cdots & x_{1 N} \\
x_{21} & x_{22} & \cdots & x_{2 N} \\
\cdots & \cdots & \cdots & \cdots \\
x_{n 1} & x_{n 2} & \cdots & x_{n N}
\end{array}\right]
$$


A matriz dos coeficientes de correlação das variáveis, que denotaremos por $\mathbf{R}$ (já analisada no item 3.2.), pode ser obtida diretamente da matriz $x$, simplesmente pós multiplicando-a pela sua transposta $X^{\prime}$. Ou seja:

$\mathbf{R}=\mathbf{X} \mathbf{X}^{\prime}=\left[\begin{array}{cccc}1 & r_{1,2} & \ldots & r_{1, n} \\ r_{1,2} & 1 & \ldots & r_{2, n} \\ \ldots & \ldots & \ldots & \ldots \\ r_{1, n} & r_{2, n} & \cdots & 1\end{array}\right)_{(\mathrm{nxn})}$


Os valores dos elementos desta matriz, considerando os dados para as microrregiões do estado da Bahia, foram apresentados na Tabela 2 .

o segundo procedimento consiste em encontrar os chamados componentes principais que nada mais são do que combinações lineares das 18 variáveis que compõem a matriz $X$. Cada componente principal assume valores diferentes em cada microrregião em função da điversidade de valores das variáveis. Temos então $n=18$ componentes principais, cada um assumindo $\mathrm{N}=25$ valores diferentes. Em forma matricial podemos expressá-los da seguinte maneira:

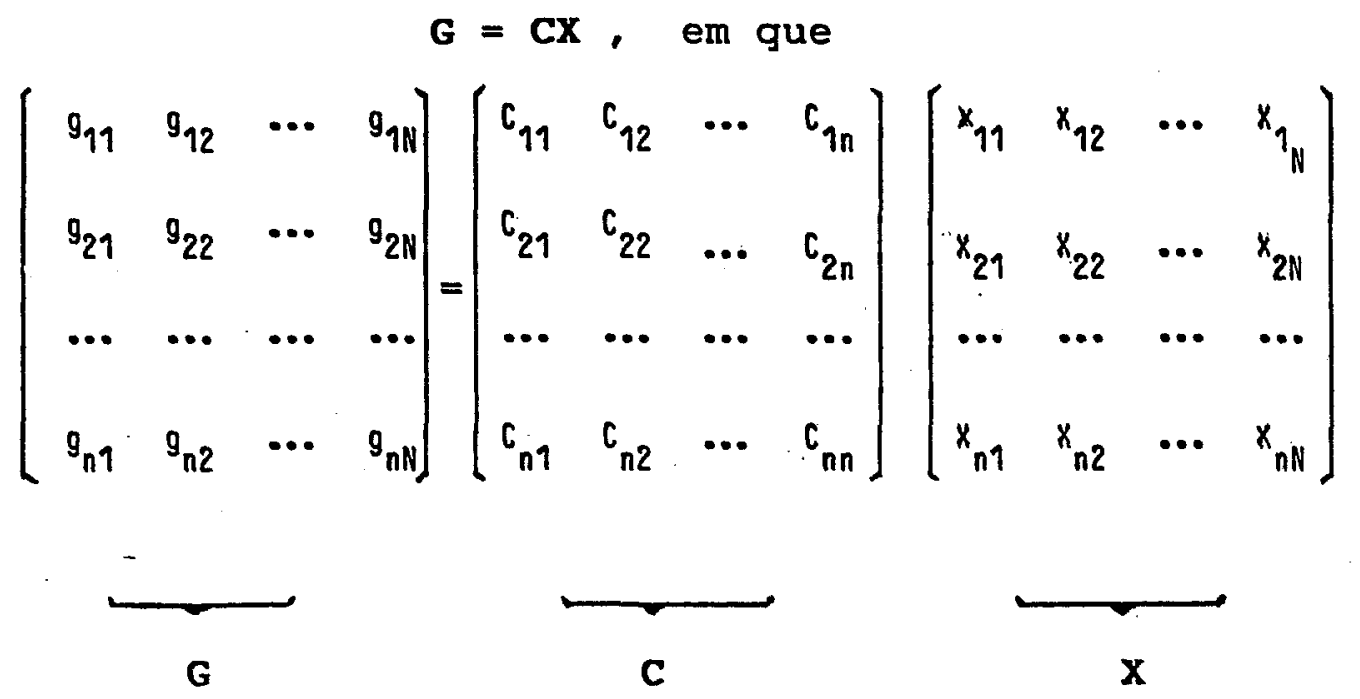

o método dos componentes principais consiste em determinar os elementos da matriz $C$ de modo que os componentes tenham variâncias decrescentes e ao mesmo tempo não estejam autocorrelacionados ${ }^{1}$. Matematicamente, estas

1 Isto quer dizer que as linhas da matriz G devem ser ortogonais entre si. 
duas condições são satisfeitas, se ao maximizar as variânCias dos sucessivos componentes impõem-se as seguintes restrigöes:

$\sum_{h=1}^{n} c_{i h} c_{j h}= \begin{cases}1 \text { se } i=j & (i=1, \ldots, n) \\ 0 \text { se } i \neq j & (j=1, \ldots, n)\end{cases}$

Ao proceder a esta maximização condicionada verifica-se que os valores dos elementos da matriz C devem cumprir o seguinte sistema de equações expresso em termos matriciais:

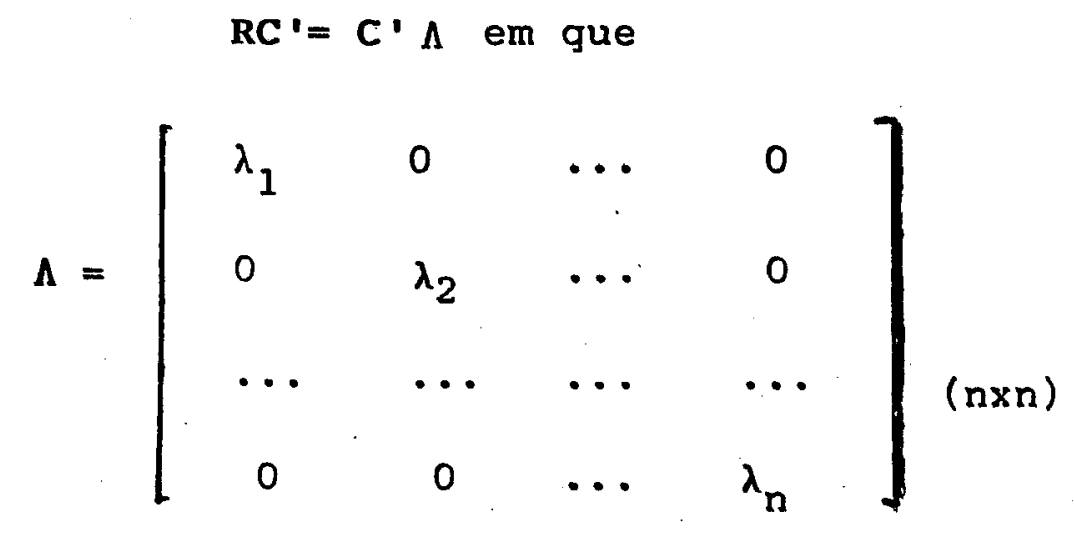

$\operatorname{com} \lambda_{1} \geqslant \lambda_{2} \geqslant \cdots \geqslant \lambda_{n}$. os $\lambda_{i}$ são as raizes caracteristicas da matriz $R$. 
Nesta formulação do problema, cada componente principal é expresso em termos de uma combinação linear das variáveis. Também podemos expressar cada uma das variáveis em termos de combinações lineares de fatores que resultam da seguinte transformação dos componentes principais.

$$
F=\Lambda^{-1 / 2} \mathbf{G} \text { em que }
$$

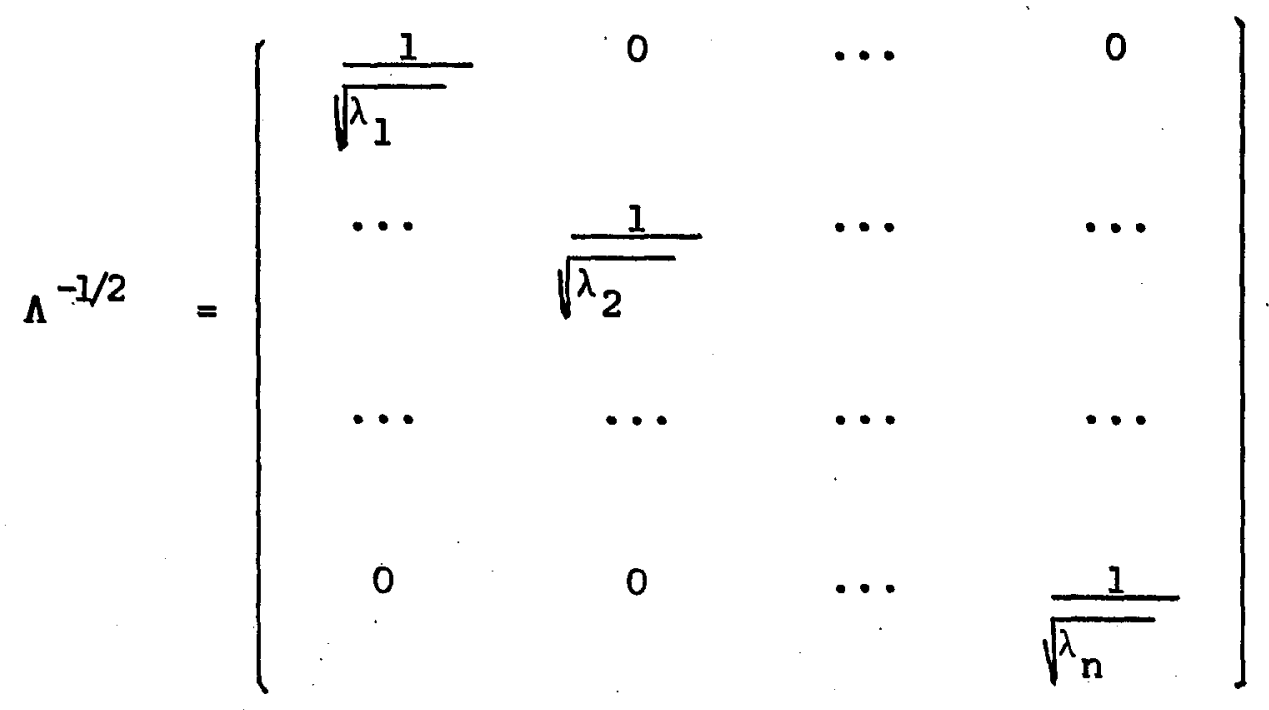

$$
A=C^{\prime} \Lambda^{1 / 2}=\left[\begin{array}{cccc}
\text { Como } G=c x & \text { então } X=A F \text { em que } \\
a_{11} & a_{12} & \cdots & a_{1 n} \\
a_{21} & a_{22} & \cdots & a_{2 n} \\
\cdots & \cdots & \cdots & \cdots \\
a_{n 1} & a_{n 2} & \cdots & a_{n n}
\end{array}\right]
$$

Como as linhas da matriz $\mathbf{F}$ são ortogonais entre si, a matriz $R=X X^{\prime}=A F P^{\prime} A^{\prime}=A A^{\prime}$. Por outro lado $A^{\prime} \cdot A^{\prime} \Lambda^{1 / 2} \dot{C} \cdot A^{1 / 2}=\Lambda$. 
Podemos agora interpretar o significado dos elementos da matriz A. Expressando cada um dos elementos da matriz $x$ como combinação linear dos $n$ fatores $f_{i j}$ ( $i=1, \ldots$. n) temos:

$$
x_{i j}=a_{i 1} f_{i j}+a_{i 2} f_{2 j}+\ldots+a_{i n} f_{n j}
$$

Multiplicando ambos os membros da equação anterior por $f_{k j}$ e somando para $j$ temos:

$\sum_{j=1}^{N} x_{i j} f_{k j}=a_{i 1} \stackrel{\sum}{j=1}_{f_{1 j}}^{N} f_{k j}+a_{i 2}{\underset{j=1}{N}}_{j}^{N} f_{2 j} f_{k j}+\ldots a_{i n} \sum_{j=1}^{N} f_{n j} f_{k j}$ Entretanto, como as linhas da matriz $\mathbf{F}$ são ortogonais entre si e tem modélo igual a 1 . $\sum_{j} f_{i j} f_{k j}= \begin{cases}0 & \text { se } i \neq k \\ 1 & \text { se } i=k\end{cases}$ Então $\sum_{j=1}^{N} x_{i j} f_{k j}=a_{i k}$ com o que o elemento $a_{i k}$ da matriz A é o coeficiente de correlação entre a variável $M_{i} e$ o fator $f_{k}$. 
Os elementos da matriz A possuem as seguintes propriedades:

$$
\begin{aligned}
& \text { Como } A^{\prime} A=\Lambda \text { temos: } \\
& \sum_{i=1}^{n} a_{i j}^{2}=\lambda_{j}
\end{aligned}
$$

Como RC'=C' $\Lambda$, então $\Lambda=C$ R C'.Por outro lado, devido às restrições impostas na maximização das variâncias dos valores dos componentes principais traço $\left(C_{R C} C^{\prime}\right)=$ traço $(R)$ e portanto $\Sigma \lambda_{j}=n$. Pode-se verificar que $\frac{\lambda_{j}}{n}$ é a proporção da variância das n variáveis explicada pelo fator $\mathbf{f}_{i} \cdot$

$$
\text { Como R=AA', podemos expressar } 0
$$

coeficiente de correlação entre as variáveis $M_{i}$ e $M_{j}$ como a soma do produto dos coeficientes de correlação de cada uma delas com cada um dos fatores $f_{h}(h=1,2 \ldots, n)$. Então

$$
\sum_{j=1}^{n} a_{i j}^{2}=1 \quad \text { e } \sum_{h=1}^{n} a_{i h} a_{j h}=r_{i j}
$$

Entretanto, nesta pesquisa só consideramos os três primeiros fatores porque eles dão conta de uma proporção elevada da variância total dos dados.

Então $\Lambda$ passa a ser uma matriz diagonal $3 \times 3$ com as três primeiras raizes características de $R$, C passa a ser uma matriz $3 \times n$ e A uma matriz nx 3 cujos elementos podem ser expressos como

$$
a_{i k}=c_{i k} \sqrt{\lambda_{k}}
$$


Como se consideraram apenas as três colunas da matriz $\mathbf{A}$, então

$$
\sum_{h=1}^{3} \quad a^{2}{ }_{h h}<1
$$

Esta expressão mostra a proporção da variância de cada uma das variáveis $M_{i}$ que é explicada (estatisticamente) pelos três primeiros fatores, e é denominada comunalidade da variáve1. Os resultados estão descritos na Tabela 6 .

$$
\text { Podemos utilizar os coeficientes } a_{i h} \text { para }
$$
indicar as variáveis originais mais estreitamente associadas com cada um dos fatores $f_{k}$. Para tanto seria conveniente que os coeficientes estivessem o mais próximos possiveis de zero ou de 1 e -1 . Esta condição pode ser imposta por uma rotação ortogonal da matriz A. É o que estabelece - critério VARIMAX, ao maximizar a variância dos quadrados dos coeficientes de cada uma das colunas da matriz A. Algumas das propriedades da matriz a são conservadas, porém outras não. Assim, por exemplo, os novos fatores obtidos permanecem não correlacionados e explicam a mesma proporção da variância total; entretanto, a contribuição de cada um dos fatores fica, em geral, alterada. Os resultados das correlações após rotação serão apresentados e discutidos no item 4.2. Após a rotação, calculou-se também o valor de cada um dos fatores nas diversas microrregiōes. 
Pabela 6: Matriz A (Coeficientes de correlação entre as varí́veis originais e os primeiros três fatores) ( 1 ).

\begin{tabular}{|c|c|c|c|c|}
\hline Variáveis & Fator 1 & Fator 2 & Futor 3 & $\sum_{i=1}^{3} a^{2} i j$ \\
\hline EMEH & 0,88663 & $-0,39568$ & 0,15960 & 0,968 \\
\hline VPES & 0,93133 & $-0,21113$ & 0,16446 & 0,939 \\
\hline MTEH & 0,55898 & $-0,56570$ & 0,30505 & 0,726 \\
\hline VBES & 0,92355 & $-0,21683$ & 0,06061 & 0,904 \\
\hline VPEH & 0,94364 & $-0,13171$ & 0,11736 & 0,922 \\
\hline VBEH & 0,93396 & $-0,22197$ & 0,01728 & 0,922 \\
\hline NIEH & 0,15491 & $-0,07459$ & 0,56599 & 0,350 \\
\hline $\cot C$ & $-0,47971$ & 0,18011 & $-0,40227$ & 0,424 \\
\hline VPAE & 0,75325 & 0,51946 & $-0,31782$ & 0,938 \\
\hline DTAE & 0,79631 & 0,45438 & $-0,29115$ & 0,925 \\
\hline VBTO & 0,85364 & 0,19308 & $-0,38790$ & 0,916 \\
\hline AOIE & 0,84392 & 0,25381 & $-0,13633$ & 0,795 \\
\hline FIAE & 0,49606 & 0,35760 & $-0,12183$ & 0,389 \\
\hline Aore & 0,02521 & 0,48586 & $-0,31544$ & 0,336 \\
\hline IRAT & 0,09359 & 0,70764 & 0,64902 & 0,931 \\
\hline AIAT & $-0,04310$ & 0,77212 & 0,51561 & 0,864 \\
\hline BOPA & 0,18463 & 0,74179 & 0,26675 & 0,655 \\
\hline A110 & 0,04032 & 0,04471 & $-0,76034$ & 0,582 \\
\hline$\sum_{j=1}^{18}{ }^{2}{ }_{j j}=\lambda_{j}$ & 7,771199 & 3,263893 & 2,45101 & 13,486 \\
\hline$\frac{\lambda_{j}}{18}$ & 0,4317 & 0,1813 & 0,1362 & \\
\hline$\frac{\lambda_{j}}{18}$ & 0,4317 & 0,6131 & 0,7492 & \\
\hline
\end{tabular}

(1) os resultados aqui obtidos assin cono us que mostrorenos odianto foran calculados por progranes do pacote ostatistico SAS no computedor Vax/UAS do UNICANP. 
Os valores obtidos para os três fatores a nível de microrregião foram usados na análise de regressão linear múltipla entre eles e os indicadores da distribuiÇão de renđa da PEÁ agropecuária antes mencionados.

Na regressão linear múltipla as observações foram ponderadas levando em conta a importância relativa de cada microrregião em termos da PEA agropecuária. (Ver Tabela 7). Justificamos este procedimento, considerando que a variância dos valores das variáveis que expressam as características da distribuição de renda é inversamente proporcional ao tamanho da PEA agropecuária das microrregiões. Como se observa, o tamanho da PEA varia muito entre as microrregiões. Os casos extremos são Cacaueira e Litoral Norte Baiano: - $\Theta$ tamanho da PEA agropecuária da primeira é quase 11 vezes o da segunda.

Com estas diferenças de tamanho da PEA agropecuária entre as microrrégiões a não consideração de que a variância dos resíduos da regressão não é constante pode conduzir a sérios problemas na aplicação do método dos mínimos quadrados ordinários, "ao estimar os coeficientes de regressão e suas variâncias ${ }^{1}$. cap. 6 . 
Tabela 7 : Fatores de ponderação das observações, utilizados na análise ponderada

\begin{tabular}{|c|c|c|c|c|c|}
\hline Microrregiōes & & $\begin{array}{c}\text { PEA - Agropecuária } \\
1980\end{array}$ & & $\begin{array}{c}\text { Participação no } \\
\text { total }\end{array}$ & \\
\hline 131 - Chapadões do Alto Rio Grande & & 39.447 & & 2,7 & \\
\hline 132 - Chapadöes do Rio Corrente & & 35.020 & & 2,4 & \\
\hline 133 - Baixo-Médio Säo Francisco & & 61.883 & & 4,3 & \\
\hline 134 - Médio São Francisco & & 31.257 & & 2,2 & \\
\hline 135 - Chapada Diamantina Setentrional & & 59.936 & & 4,1 & \\
\hline 136 - Chapada Diamantina Meridional & & 110.736 & & 7,6 & \\
\hline 137 - Serra Geral da Bahia & & 114.794 & & 7,9 & \\
\hline 138 - Senhor do Bonfim & & 36.971 & & 2,6 & \\
\hline 139 - Piemonte da Diamantina & & 74.528 & & 5,1 & \\
\hline 140 - Corredeiras do São Francisco & & 18.859 & & 1,3 & \\
\hline 141 - Sertão de Canudos & & 54.888 & & 3,8 & \\
\hline 142 - Serrinha & & 64.115 & & 4,4 & \\
\hline 143 - Feira de Santana & & 103.109 & & 7,1 & \\
\hline 144 - Jequié & $\cdot$ & 77.593 & & 5,4 & \\
\hline 145 - Planalto de Conquista & & 74.629 & & 5,1 & \\
\hline 146 - Pastoril de Itapetinga & & 21.027 & & 1,5 & \\
\hline 147 - Sertão de PauloeAfonso & $\ldots$ & 23.528 & & 1,6 & $\therefore$ \\
\hline 148 - Agreste de Alagoinhas & & 81.430 & & 5,6 & \\
\hline 149 - Litoral Norte Baiano & & 13.094 & & 0,9 & \\
\hline 151 - Recôncavo Baiano & & 63.350 & & 4,3 & \\
\hline 152 - Tabuleiros de Valença & & 44.847 & & 3,1 & \\
\hline 153 - Encosta do Planalto de Conquista & & 36.047 & & 2,5 & \\
\hline .154 - Cacaueira & & 141.439 & - & 9,8 & \\
\hline 155 - Interiorana do Extremo Sul da Bahia & & 32.804 & . & 2,3 & $\cdots$ \\
\hline \multirow[t]{2}{*}{156 - Litorânea do Extremo Sul da Bahia } & . & 34.001 & & 2,4 & \\
\hline & & 1.449 .332 & & 100,0 & \\
\hline
\end{tabular}


o estimador dos parâmetros da regressão linear múltipla de acordo com o método de mínimos quadrados ponderados pode ser expresso em forma matricial da seguinte maneira:

$$
b=\left(F^{\prime} W^{-1} F\right)^{-1} F^{\prime} \cdot W^{-1} V
$$

onde $\mathbf{w}^{-1}$ é a matriz diagonal dos fatores de ponderação.

No próximo capítulo, discutiremos com detaThe os resultados da aplicação destes métodos. 


\section{ANÁLISE DOS RESULTADOS}

Com base na análise de componentes principais, a partir dos valores da-matriz $F$ dos fatores a nivel de microrregião foi feita uma regionalização da atividade agropecuária do estado da Bahia. A seguir, realizou-se uma análise de regressão entrè características da distribuição de renda das microrregiões e os valores assumidos pelos fatores em cada uma delas.

Neste capítulo discutem-se os resultados das análises, após apresentar uma caracterização preliminar da agricultura na Bahia.

4.1. Uma Caracterização Preliminar da Agropecuária ja Bahia

A heterogeneidade de situações ao nível de microrregiões na Bahia pode ser brevemente ilustrada com algumas observações extraídas de Lacerda de Melo (1978), 
que se baseou no Censo Demográfico de 1970 e em dados de produção agropecuária de 1974 , as quais complementamos com os dados dos Censos Agropecuário e Demográfico de 1980 (Ver Tabelas A.2.3, A.2.4, A.2.5 e A.2.6 no Anexo 2).

$$
\text { MELO (1978) denomina : Área do Sis- }
$$

tema Cacaueiro às microrregiões de Tabuleiros de Valença (152) e Cacaueira (154) (Ver Mapa 2.). Em conjunto essas microrregiões detêm $11,2 \%$ da população economicamente ativa do estado e 12,7\% da vinculada à agropecuária, extração vegetal e pesca. Elas respondem por $27,0 \%$ do valor da produção agropecuária do estado da Bahia.

Predomina a produção de cacau, : embora nas menores propriedades também sejam importantes as lavouras tradicionais de mandioca, milho e feijão, para autoconsumo ou venda em mercados locais. A sazonalidade do trabalho é muito pronunciada, destacando-se a época da colheita principal (dé Setembro a Dezembro), em que predomina o trabalho temporário de residentes em lugarejos e pequenas cidades próximas.

Existem, entretanto, diferenças importantes entre as duas microrregiões em termos de composição da produção agropecuária. A participação das lavouras permanentes no valor da produção da microrregião é maior na Cacaueira (95\%) do que em Tabuleiros de Valença ( $84 \%$ ). Também são diferentes o peso do cacau no valor da produção 
MAPA 2 BAHIA - ESPAGOS AgRARIOS

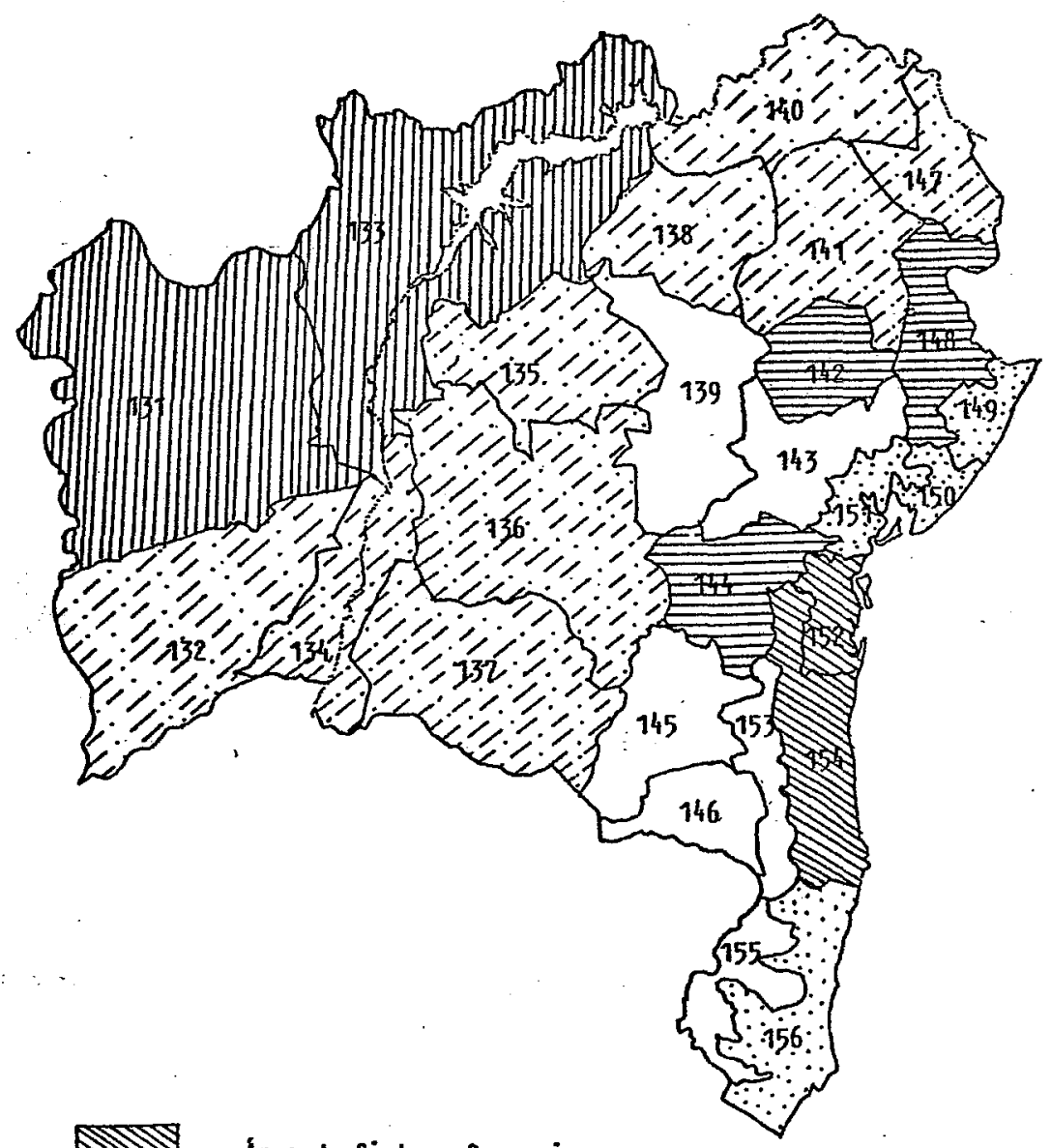

- Área do Sistema Cacaueiro

- Areas Agropastoris com Combinúções

$\because \vdots: \vdots:$

Agricolas Subcosteiras

$\rightleftharpoons$

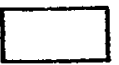

- Areas do Sistewa Gado-Policultura

- Rreas de Pecuaria Melhorada

Vi:itid

- Areas Agropastoris com Camamações Agricolas Sertanejas

[D.|.|.|. II - Areas de Baixa Ocupação do Solo

Rio Sào Erancisco

TONTE: HELO(1978) 
das lavouras permanentes. Na Cacaueira, 97\% do valor da produção das lavouras permanentes correspondem ao cacau enquanto em Tabuleiros de Valença essa proporção é $64 \%$, sobressaindo entre os outros produtos da lavoura permanente - cravo da fndia (13\%) e a borracha ( $8 \%$ ).

As outras microrregiões que junto às da Area Cacaueira cobrem o litoral do estado da Bahia formam o que Mário Lacerda chama de Áreas Agropastoris com Combinações Agrícolas Subcosteiras. Abrangem o Litoral Norte Baiano (149), Salvador (150), Recôncavo Baiano (151) e Iitorânea do Extremo Sul da Bahia (156). Embora abarquem 29,4\% da população ativa total do estado, participam com somente 8,6\% da PEA vinculada à agricultura, extração vegetal e pesca. Respondem por $10,5 \%$ do valor da produção agropecuária do estado da Bahia.

Nas quatro microrregiões homogêneas pesa a produção de coco-da-Bahia e mandioca, mas são bastante diferentes a importância e composição da produção agropecuária. Assim, o Litoral Norte Paiano é, junto com sertão de Paulo Afonso, a microrregião homogênea do estado da Bahia com menor valor de produção agropecuária, enquanto o Recôncavo Baiano é a terceira microrregião da Bahia em termos de valor da produção agropecuária, somente superada pelas microrregiões Cacaueira e de Jequié.

No Iitoral Norte Baiano a atividade agropecuária é pouco diversificada, destacando-se que $81 \%$ do va- 
lor da produção das lavouras permanentes correspondem ao coco-da-Bahia e $87 \%$ do de lavouras temporárias devem-se à mandioca.

Na microrregião de salvador a produção agropecuária é um pouco mais expressiva e diversificada, incluindo como atividades expressivas a horticultura e floricultura ( $9 \%$ do valor da produção total agropecuária). Nas lavouras permanentes a participação do coco-da-Bahia no valor da produção é um pouco menor (cerca de 71\%), por causa da produção de banana (15\%); nas lavouras temporárias, a menor proporção do valor de produção de mandioca é acompanhada do maior peso da cana-de-açúcar.

A microrregião Iitorânea do Extremo sul da Bahia tem produção ağropecuária bem mais expressiva - que as de Salvador e Iitoral Norte Baiano. O tipo de prođução também é bastante diferente. Destaca-se o valor da produção de animais de grande porte $(36 \%)$ frente às lavouras permanentes (26\%), as lavouras temporárias (23\%) e extração vegetal (11\%). Nè lavouras permanentes é bem menor a proporção do valor de produção-dé coco-da-Bahia, crescendo agora a importância do cacau e do mamão. Já nas lavouras temporárias, à menor proporção do valor da produção de mandioca corresponde um maior peso da produção de feijão e abóbora. 
No entanto, a principal microrregião das Areas Agropastoris com Combinações Agrícolas Sub-Costeiras é a do Recôncavo Baiano. Nela sobressai o valor da produção de lavouras temporárias (43\%); seguem-se os animais de grande porte (16\%); aves e pequenos animais (12\%) e lavouras permanentes (20\%). Entretanto; nas lavouras permanentes e temporárias a produção é bem mais diversificada. Nas permanentes destacam-se banana, laranja, coco-da-Bahia, dendê e uma série de frutas tropicais como jaca, maracujá, manga, abacate e caju. Estas frutas respondem em conjunto por $17 \%$ do valor da produção das lavouras permanentes do Recôncavo Baiano. Já nas lavouras temporárias sobressaem mandioca, cana-de-açúcar, fumo e feijão.

As 18 microrregiões situadas entre o litoral e o Extremo Noroeste da Bahia foram classificadas por MELO (1978) : em três tipos de área de produção agropecuária. As microrregiões de Agreste de Alagoinhas (148), Serrinha (142) e Jequié (144) formam a área de Gado-Policultura. A área do Sistema de Pecuária Melhorada é formada pór 6 microrregiões: Piemonte de Diamantina (139), Feira de Santana (143), Planalto da Conquista (145), Pastoril de Itapetinga (146), Encosta do Planalto da Conquista (153) e Interiorana do Extremo Sul da Bahia (155). As outras 9 microrregiões formam as Areas Agropastoris com Combinações Agrícolas Sertanejas, ou seja, Chapadões do Rio Corrente (132), Médio São Francisco (134), Chapada Diamantina Se- 
tentrional (135), Chapada Diamantina Meridional (136), Serra Geral da Bahia (137), Senhor do Bonfim (138), Corredeiras do são Francisco (140), Sertão de Canudos (141), Sertão de Paulo Afonso (147).

Na Area do Sistema Cacaueiro, e também nas Areas Agropastoris com Combinações Agrícolas Subcosteiras, a participação no valor da produção agropecuária total do estado é maior que a participação na população ativa vinculada à atividade agropecuária. Na Área do sistema de Pecuária Melhorada são iguais as participações no valor da produção e na população ativa da agropecuária e na Area do Gado-Policultura e principalmente nas Areas Agropastoris com Combinações Agrícolas sertanejas, pelo contrário, é maior a participação na população ativa vinculada a agropecuária. Além disso, nesta última área de produção agropecuária, comparativamente às demais, a participação na PEA agrícola do estado supera em muito a participação na PEA total, indicando uma grande dispersão de população pelo campo praticando de modo extensivo as atividades agropecuárias.

MELO (1978). chama a atenção para o fato de que em Corredeiras de são Francisco e Sertão de Pau10 Afonso a aridez do solo praticamente inviabiliza a lavoura, exceto em áreas de irrigação para produtos de alto valor comercial. Efetivamente, em Corredeiras de são Francisco as lavouras temporáriäs respondem por 50\% do valor da 
produção agropecuária, destacando-se nela a produção de cebola (36\%), feijão $(37 \%)$, arroz $(5 \%)$, tomate $(5 \%)$ e melancia (4\%). Na produção animal desta microrregião homogênea sobressaem os animais de médio porte, notadamente caprinos e ovinos. Já no Sertão de Paulo Afonso, pesa bem mais o valor da produção de animais de grande porte ( $54 \%$ ) e menos o da lavoura temporária (29\%), onde predominam o feijão e a palma forrageira, esta última quase exclusivamente no município de coronel joão sá. Conforme ilustra ANDRADE (1982), esse município está vinculado econômica e socialmente muito mais às cidades fronteiriças sergipanas, com pecuária mais desenvolvida, do que às cidades baianas desta microrregião, especialmente paulo Afonso (147): Tudo parece indicar, então, gue a palma forrageira produzida destina-se à pecuária moderna de sergipe e não à pecuária extensiva e atrasada das caatingas da microrregião de Paulo Afonso.

A produção agrícola e a pecuária extensiva são mais expressivas nas microrregiões de senhor do Bonfim e Sertão de Canudos. Nesta última, a produção é pouco diversificada, destacando-se a de animais de grande (34\%) e médio ( $14 \%$ ) porte, a lavoura permanente (26\%), onde sobressai o agave para a fabricação de sisal, e as lavouras temporárias (16\%), onde sobressaem feijão, manđioca e mi1ho. Já na microrregião de Senhor do Bonfim a produção é um pouco mais diversificada, destacando-se, pelo valor da 
produção, animais de grande porte (30\%), lavouras permanentes ( $22 \%$ ) e temporárias ( $35 \%$ ). Nas lavouras permanentes é menor o peso da produção de agave por causa da importância relativa da produção de banana, mamona, café e manga, produtos que em área plantada superam o agave. Nas lavouras temporárias são importantes as lavouras de feijão, mandioca e milho.

Na Chapada Diamantina Setentrional a pecuária é menos importante, destacando-se quase que exclusivamente o valor da produção das lavouras temporárias (70.\%). Estas são bastante diversificadas, despontando o feijão, o milho e a mandioca. Como observou Mário Lacerda, o solo é fértil e os cultivos são intensivos, inclusive com mecanização. Trata-se de uma-zona-de-atração de população, fato raro no Nordeste, sobressaindo o município de Irecê.

Do lado Meridional da Chapada da Diamantina volta a predominar a pecuária extensiva e os cultivos se restringem a zonas de regadio em fundo de vales. são importantes a produção de animais de grande porte $(30 \%)$ e a lavoura temporária $(41 \%)$ e permanente $(16 \%)$. Nesta última destaca-se a produção de café, mas também são importantes as de mamona, banana e laranja, se não pelo valor da produção, pela magnitude da área plantáda. Nas lavouras temporárias destacam-se feijão, milho, mandioca além de arroz, cana-de-açúcar, fumo e algodão. 
A pecuária extensiva e a lavoura temporária diversificada viabilizada por irrigação rústica prosseguem na microrregião Serra Geral da Bahia, que abrange a parte baiana da serra do Espinhaço. Na pecuária, predominam os animais de grande porte (31\%) e nas lavouras temporárias (48\%) são importantes o feijão, o algodão, o arroz, o miIho, a mandioca e a cana-de-açúcar.

o algodão também está presente na agricultura precária do Médio são Francisco. Predominam a produção de animais de grande porte (38\%) e a lavoura temporária (46\%). Nesta última, mais importante que a produção de algodão é a de feijão e milho, não sendo desprezíveis as de arroz e mandioca.

Finalmente, na-microrregião de Chapadões do Rio Corrente a agricultura é um pouco melhor. Pesa mais - valor da produção de animais de grande porte (52\%) e nas Iavouras temporárias (34\%) sobressaem feijão, milho, arroz, mandioca e cana-de-açúcar.

Na Area de Gado-Policultura, em Agreste de Alagoinhas e Serrinha predomina a pecuária de leite em detrimento da policultura alimentar tradicional. Conforme Iacerda de Melo, esta seria a razão pela qual é menor a densidade demográfica dessas microrregiões comparativamente a Jequié, onde é maior o peso da policultura.

De fato, o valor da produção de animais de grande porte pesa bem mais em Agreste de Alagoinhas (46\%) 
e Serrinha (38\%) do que em Jequié (19\%). Entretanto, em Serrinha, a lavoura permanente (45\%) é mais importante que a temporária (9\%), ao contrário da microrregião Agreste de Alagoinhas, onde a lavoura temporária (36\%) pesa mais que a permanente ( $8 \%$ ). Por lavoura permanente, em Serrinha, entende-se exclusivamente a produção de agave (99\%), enquanto na lavoura temporária do Agreste de Alagoinhas são importantes feijão e mandioca, além de milho e fumo.

Em Jequié as lavouras permanentes

são ainda mais importantes que as temporárias (23\%). Nas permanentes destacam-se a produção de cacau (65\%), café e banana. Nas temporárias sobressaem. a produção de mandioca, feijão, tomate, milho e abóbora. MELO (1978), entretanto, observou que tem ocorrido um avanço da pecuária em prejuízo da lavoura. Com exceção de produtos específicos de agricultura mais moderna como fumo, tomate e cebola, o predomínio da lavoura só tem se sustentado no minifúndio atrasado e a pecuarização tem prejudicado o abastecimento de gêneros alimentícios e matérias-primas para a indústria ou para a exportação.

Nas microrregiões da Area do Sistema de Pecuária Melhorada predomina uma pecuária moderna que abastece de carne boa parte do Nordeste, notadamente Recife e Salvador. A lavoura é secundária, embora só não seja ponderável em Pastoril de Itapetinga onde $80 \%$ do valor da produção deve-se a añimaîs de grande porte. Mesmo nesta re- 
giãıas lavouras permanentes respondem por $13 \%$ do valor da prođụ̂̃o, desstacando-se café e cacau.

As lavouras permanentes só não são importantes em Feira de Santana. Nesta microrregião, a produção de animais de grande porte (54\%) convive com lavouras temporárias ( $31 \%$ ), onde se destacam mandioca, feijão, fumo, abacaxi, abóbora e milho.

Em Piamonte de Diamantina, ao lado da produção de animais de grande porte (55\%) e das lavouras temporárias (23\%) não é desprezível a produção de lavouras permanentes: (15\%). Nela destacam-se a produção de agave, banana e café. Nas culturas temporárias desta microrregião sobressaem mandioca, feijão e milho.

A produção das lavouras permanentes é mais expressiva no Planalto da Conquista (35\%), sendo quase tão importante quanto a das lavouras temporárias ( $32 \%$ e mais que a produção de grandes animais (25\%). Destaca-se a produção de café e secundariamente a de cacau. Nas culturas temporárias desta microrregião os produtos i piportantes são feijão, mandioca e milho.

As lavouras permanentes ( $35 \%$ ) na Encosta do Planalto da Conquista são pouco mais expressivas do que as lavouras temporárias (32\%). Na Interiorana do Extremo Sul da Bahia, as lavouras permanentes (45\%) superam as lavouras temporárias (16\%). Na Encosta do Planalto da Conquis- 
ta, praticamente o único produto de cultura permanente é o cacau (97\%). Ele também pesa muito no valor da produção da Interiorana do Extremo Sul da Bahia (89\%) mas, nesta última microrregião, não é desprezível a produção de café $(6 \%)$

Além das cinco Areas de Produção Agropecuária mencionadas, MELO: (19.78) definiu uma sexta, a que chamou de Areas de Baixa Ocupação do Solo, em que inclui as microrregiões de Chapadões do Alto Rio Grande (131) e Baixo Médio São Francisco (133). Não obstante, os Censos Demográfico e Agropecuário de 1980 indicam que essas microrregiões em conjunto, abarcavam $4,2 \%$ do valor da produção agropecuária do estado da Bahia, contribuindo para o emprego de $4,5 \%$ da PEA total e $6,9 \%$ da vinculada à agropecuária.

Em Chapadões do Alto Rio Grande, pesam a produção de animais de grande-porte (44\%) e as lavouras temporárias ( $44 \%$ ), notadamente feijão, milho, arroz e mandioca. Em Baixo Médio são Francisco, além das lavouras temporárias (53\%) da produção de animais de grande porte (22\%) são importantes os animais de porte médio (13\%). Nas lavouras temporárias sobressaem feijão, mandioca, milho e cebola não sendo desprezíveis melancia e arroz, esta úitima se não em valor da produção ao menos em área cultivada. 
Em síntese, o estado da Bahia apresenta uma gama muito grande de situações diferentes em termos de produção agropecuária ao nível de suas microrregiões homogêneas. Tal heterogeneiđade espacial da produção agropecuária é, em princípio, conveniente para a análise da relação entre as peculiaridades desta produção em cada microrrégião e as características da distribuição da renda da PEA vinculada à agropecuária.

Não obstante, observou-se a existência de certo grau de especialiżação na produção de várias das microrregiões homogêneas do estado da Bahia. Isto pode dificultar a interpretação dos resultados do exame das diferenças entre microrregiões (em termos de sua modernização) e sua associação com as características da distribuição de renda. Isto porque a diferenciação em termos da produção agropecuária pode mascarar as possíveis associações entre modernização e renda.

Cabe aqui distinguir os trabalhos que tomam como unidade de análise os es’ados da Federação daqueles em. que as unidades são as microrregiões homogêneas de determinado estado. No caso da análise da relação entre as peculiaridades de proḑução agropecuária dos vários estados e as características da distribuição de renda, seus resultados poderiam mais facilmente ser interpretados em termos de relação entre grau de modernização e distribuição de renda. 
Se 7 to porque, de um modo geral, um grande número desschses produz uma ampla gama de produtos agropecuários, embora possa variar muito entre eles a composição específica desses produtos. Neste caso, as variáveis usadas para captar as peculiaridades da produção agropecuária de cada estado dão indicações que podem ser interpretadas em termos do grau de modernização.

No caso específico do estado da Bahia, a especialização das microrregiões em termos de produção agropecuária prejudica o uso das mesmas variáveis na medição do grau de modernização da produção agropecuária. As diferenças observadas entre microrregiões podem não corresponder, propriamente, a graus de modernização distintos na produção de uma gama semelhante de produtos, mas estar relacionadas com estruturas de produção diferentes ao nível dos produtos.

Assim, por exemplo, quando comparamos indicadores como proporção de terras irrigadas no total de terras trabalhadas, número de tratores por área trabalhada ou proporção dos estabelecimentos que usam adubação química nos estados de são Paulo e Bahia podemos ter uma idéia da diferença de grau de modernização na produção agropecuária desses dois estados. Embora variando a composição dos prođutos, em ambos são importantes a pecuária e a produção de café, feijão, milho, mandioca, cana-de-açúcar etc. A situação é diferente quando comparamos o valor dessas mes- 
mas variáveis nas diversas microrregiões do estado da $\mathrm{Ba}-$ hia. É mais difícil interpretar as diferenças no valor daquelas variáveis entre uma microrregião especializada em pecuária como Pastoril de Itapetinga, outra em que predominam as lavouras temporárias como Chapada de Diamantina Setentrional ou outra com lavouras permanentes, como a microrregião Cacaueira.

Vale dizer, o significado de cada uma das variáveis que medem o grau de modernização agropecuária varia de um tipo de produto a outro. Dessa maneira, especialmente quando as microrregiões tem especialização distinta, diferenças no valor de uma única variável não significam, necessariamente, diferentes graus de modernização. Assim, por exemplo, o menor uso de tratores por área trabalhada não significa necessariamente que a produção de cacau da microrregião Cacaueira é menos moderna do que a das lavouras temporárias da Chapada Diamantina Setentrional.

Essa dificuldade pode ser contornada através do uso di: análise fatorial, que permite levar em consideração, simultaneamente, um grande número de variáveis. 


\subsection{Identificação dos fatores}

A análise da matriz $A$, que contém os coeficientes de correlação entre as 18 variáveis e os 3 fatores obtidos, permite estabelecer o significado econômico dos fatores.

Os dois primeiros fatores respondem cada um deles isoladamente por uma alta parcela da variância total das 18 variáveis medidas nas 25 microrregiões. Ao terceiro fator corresponde uma variância um pouco menor, mas os três juntos respondem por $74,9 \%$ da variância total. (Ver Tabela 8).

- Para a maior parte das variáveis os três fatores explicam uma grande proporção da variância, como mostra a última coluna da Tabela 8. As principais exceções são: número de tratores por equivalente-homem (NTEH), proporção dos financiamentos obtidos de fontes governamentais CGTC), valor total dos financiamentos por hectare de área explorada (FIAE), proporção dos estabelecimentos que usam adubação orgânica (AOTE) e proporção trabalhađa da área total (ATTO).

As variáveis mais estreitamente relacionadas com o primeiro fator são as duas variáveis associadas com - uso de trabalho assalariado (proporção do emprego temporário e do total de assalariados em equivalentes-homem, 
Tabela 8 : Matriz A após rotação pelo Método VARIMAX (consideran do só os três primeiros fatores)

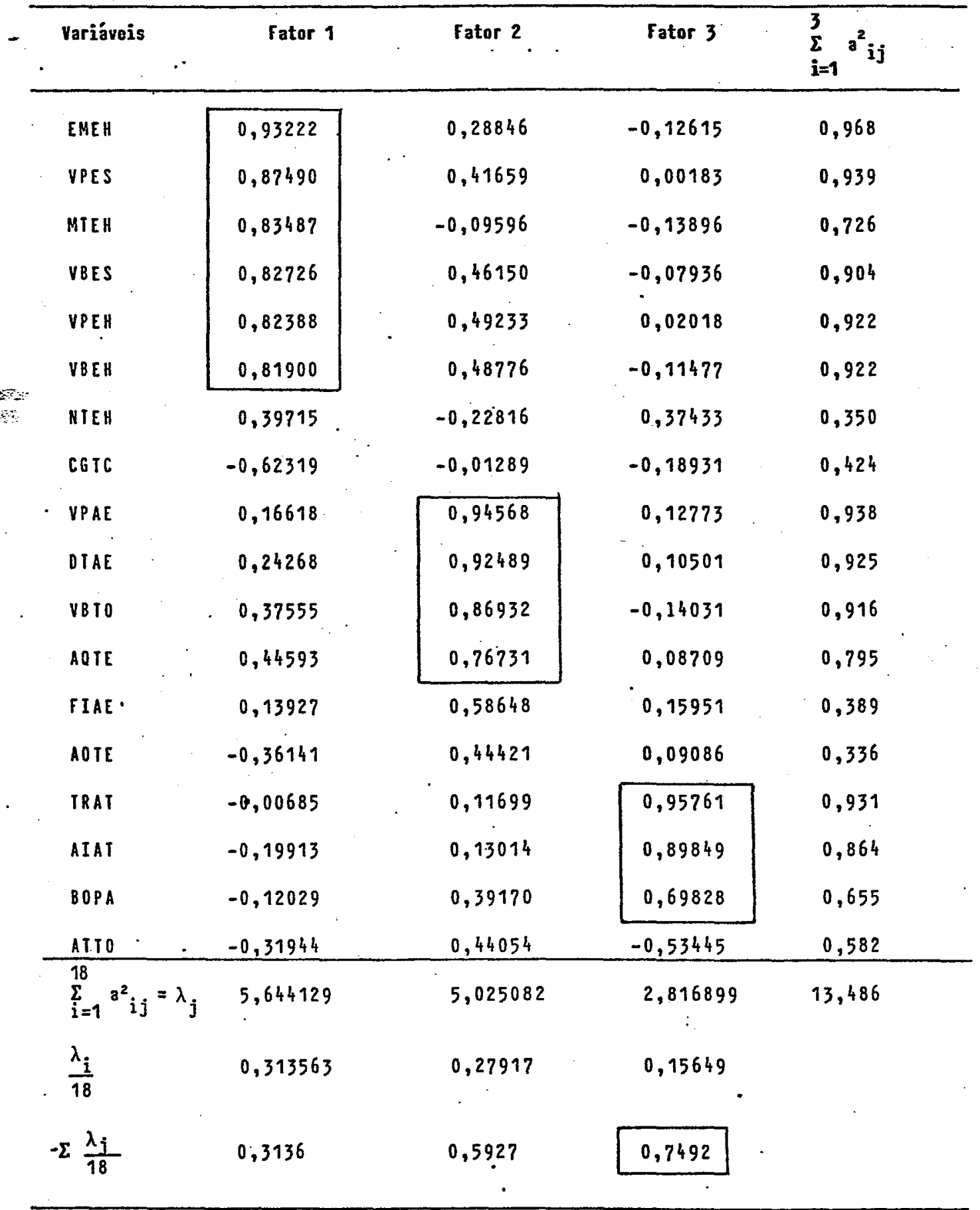


MTEH e EMEH respectivamente), as duas variáveis associadas à :escala do empreendimento (valor da produção por estabelecimento, VPES, e valor dos bens por estabelecimento, VBES), e duas variáveis associadas à capacidade produtiva da força de trabalho (valor dos bens por equivalente-homem, VBEH, e valor da produção por equivalente-homem, VPEH). A outra variável associada à produtividade do trabalho, número de tratores por equivalentes-homem (NTEH), não expressa bem a intensidade de capital dos processos de trabalho existentes na produção agropecuária baiana porque o trator não é muito importante nem nas culturas permanentes de cacau nem nas áreas de pecuária melhorada.

Podemos então dizer que o primeiro fator indica simultaneamente intensidade de uso do trabalho assalariado, escala de empreendimento e produtividade do trabaIho, ou seja, a combinação fundamental da modernização capitalista da agricultura.

O segundo fator se apresenta fortemente associado com quatro variáveis indicadoras de intensidade da exploração da terra (valor da produção por hectare de área explorada, VPAE; total das despesas por hectare de área explorada, DTAE; valor dos bens por hectare de área total, VBTO, e proporção dos estabelecimentos que usam adubos químicos, AQTE). Portanto, o segundo fator expressa intensidade de exploração da terra. Note-se que a intensificação do uso da terra nas: condições da: agricultura nordestina nem sempre 
implica adoção em escala elevada de insumos químicos e bens de capital-comprados da indústria, pois parte do valor das despesas e do valor dos bens representa gastos ou estoques com insumos ou bens "tradicionais". É o caso, por exemplo, das despesas com cota-parte de parceiros e arrendamento de terras, ou do valor dos bens em culturas permanentes, matas e animais de trabalho:

Finalmente, o terceiro fator está estreitamente associado às variáveis número de tratores por 1000 hectares de área trabalhada (TRAT), proporção irrigada da área trabalhada (AIAT), e número de bovinos por hectare de área total de pastagens (BOPA). Todas essas variáveis indicam intensidade do uso da terra mas num sentido algo diferente do anterior. As variáveis associadas ao segundo fator captam a intensidade do uso da terra num sentido bruto, tal como expressado peids valores totais da produção, dos bens e das despesas por unidade de área total e/ou explorada. Por sua vez, as variáveis relacionadas com o terceiro fator indicam intensidade do uso do solo num sentido mais específico, que envolve um detalhamento do valor dos bens e das despesas por área trabalhada. No caso do estado da Bahia é possível associar especialmente o número de tratores por área trabalhada e a proporção irrigada da área trabalhada ao uso de uma "tecnologia de ponta" na agricultura. 
Em resumo, os três primeiros fatores obtidos da análise dos componentes principais dos valores das 18 variáveis medidas nas 25 microrregiões do estado da Bahia conseguem isolar adequadamente três aspectos diferentes da modernização da atividade agropecuária. Por meio deles foi feita, em primeiro lugar, uma regionalização da atividade agropecuária da Bahia e, em segundo, uma análise das relações entre as peculiaridades da prođução agropecuária de cada microrregião e as características da distribuição de renda da PEA agrícola. Disto tratam os dois próximos itens. 
4.3. Achização agrícola da Bahia: Unạa tentativa de Caracterização Regional a partir dos fatores

\begin{abstract}
Os valores assumidos pelos três fatores nas 25 microrregiões do estado da Bahia (Ver Tabela 9), junto com a composição do valor da produção agropecuária de cada uma delas, permitiu agrupá-las em pelo menos seis áreas típicas, que poderiam ser chamadas de seis "padrões de produção agropecuária". As figuras 1,2 e 3 nos ajudam a visualizar melhor estes agrupamentos.
\end{abstract}

Em primeiro lugar temos a zona Cacaueira, formada pelas microrregiões Cacaueira (154) e Tabuleiros de Valença (152). Estas duas microrregiões estão situadas no primeiro quadrante da figura 1, apresentando valores relativamente altos para os fatores F1 e F2, não havendo nenhuma outra microrregião perto delas. Nas figuras 2 e 3 encontram-se posicionadas no quarto quadrante por apresentarem valores negativos para F3. Podemos então dizer que - grau de modernização nestas duas microrregiões caracteriza-se principalmente pelo uso intensivo do trabalho assalariado, grande escala de empreendimento e alta produtividade do trabalho (fator F1), bem como elevada intensidade de exploração da terra (fator F2). Porém, não se destacam com relação aos aspectos da intensidade do uso do solo que associamos a tecnologia de ponta (fator F3). 
Tabela 9 : Matriz F. Valor dos três primeiros fatores para as microrregiões do estado da Bahia, 1980.

\begin{tabular}{|c|c|c|c|}
\hline Hicrorregiões & F ator 1 & Fator 2 & Fator 3 \\
\hline 131 - Chapadöes do Alto Rio Grande & 0,3286 & $-1,3987$ & $-0,20519$ \\
\hline 132 - Chapadões do Rio Corrente & $-0,3405$ & $-0,7551$ & $-0,66077$ \\
\hline 133 - Baixo Médio Sạ̃o Francisco & $-0,2866$ & $-0,9427$ & 0,13161 \\
\hline 134 - Médio São Francisco & $-0,4910$ & $-0,7657$ & $-0,29255$ \\
\hline 135 - Chapada Diamantina Setentrional & 0,4810 & $-0,4683$ & 0,58652 \\
\hline 136 - Chapada Diamantina Meridional & $-0,9499$ & 0,0500 & 0,12982 \\
\hline 137 - Serra Geral da Bahia & $-0,6837$ & $-0,4269$ & $-0,11949$ \\
\hline 138 - Senhor do Bonfim & $-0,8609$ & $-0,3131$ & $-0,38093$ \\
\hline 139 - Piemonte da Diamantina & $-0,0473$ & $-0,5328$ & $-0,57475$ \\
\hline 140 - Corredeiras do São francisco & $-0,8631$ & 0,7433 & 4,28012 \\
\hline 141 - Sertão de Canudos & $-0,6562$ & $-0,6022$ & $-0,67386$ \\
\hline 142 - Serrinha & $-0,2880$ & $-0,1804$ & $-0,37777$ \\
\hline 143 - Feira de Santana & $-1,2003$ & 0,5286 & $-0,80528$ \\
\hline 144 - Jequié & $0,6,654$ & 0,1628 & 0,12700 \\
\hline 145 - Planalto da Conquista & 0,1580 & $-0,3908$ & 0,41528 \\
\hline 146 - Pastoril de Itapetinga & 2,4928 & $-0,7598$ & 0,77786 \\
\hline 147 - Sertão de Paulo Afonso & $-0,6907$ & $-0,3528$ & $-0,59876$ \\
\hline 148 - Agreste de Alagoinhas & $-1,1553$ & 0,5948 & $-0,58240$ \\
\hline 149 - Litoral Norte Baiano & $-0,0113$ & $-0,2479$ & $-0,11312$ \\
\hline 151 - Recôncavo Baiano & $-1,3966$ & 1,8042 & 0,28258 \\
\hline 152 - Tabuleiros de Valença & 0,2449 & 1,5992 & $-0,60474$ \\
\hline 153 - Encosta do Planalto da Conquista & 1,5657 & 0,4485 & $-0,29594$ \\
\hline 154 - Cacaueira & 1,5683 & 3,1825 & $-0,81229$ \\
\hline 155 - Interiorana do Extr.Sul da Bahia & 1,2754 & $-0,3010$ & $-0,16285$ \\
\hline 156 - Litorânea do Extr.Sul da Bahia & 1,2015 & $-0,6758$ & 0,52929 \\
\hline
\end{tabular}




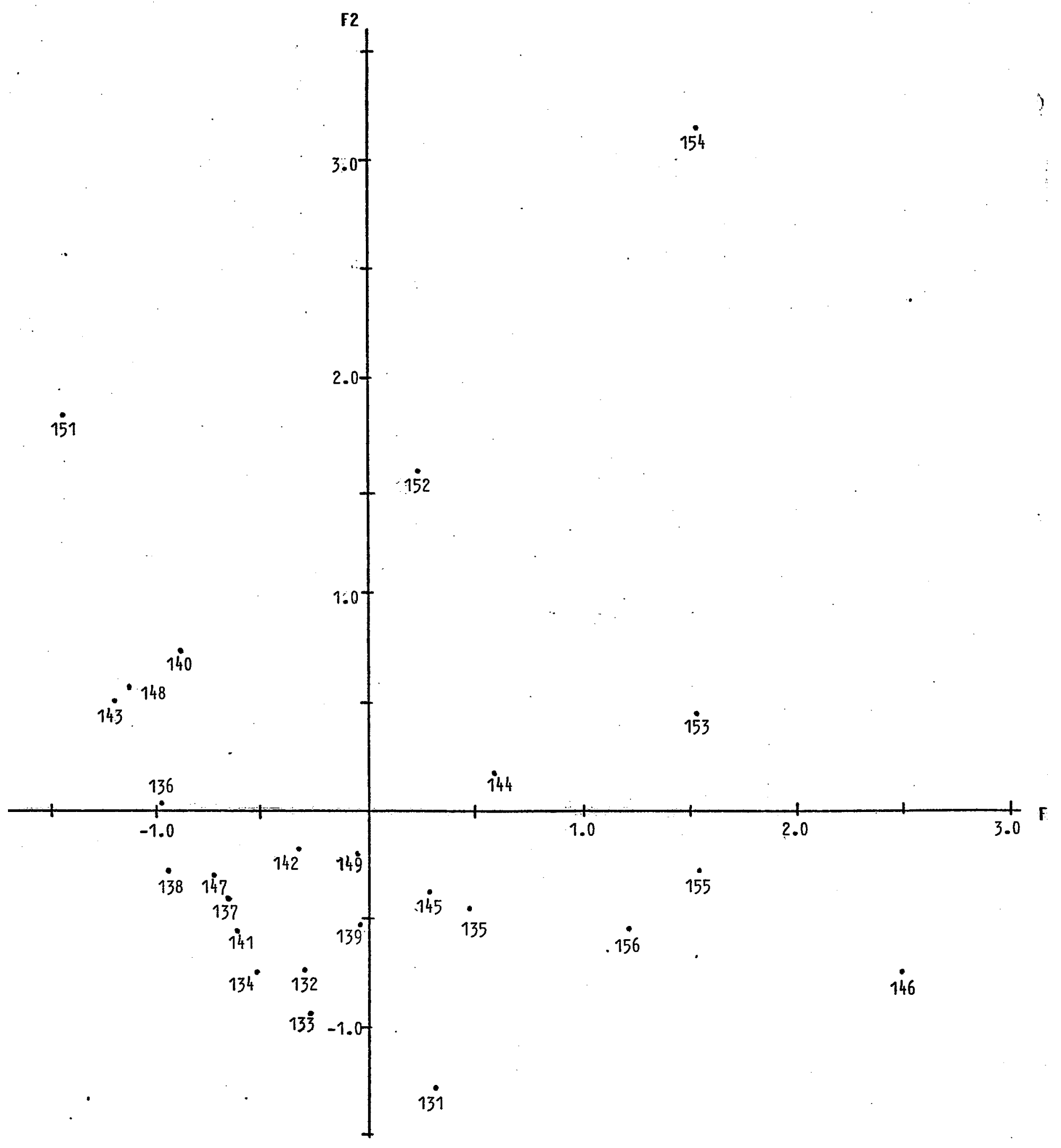

Fiqura 1 : Valores dos fatores F1 e F2 por microrregiões do estado da Bahĩa. 


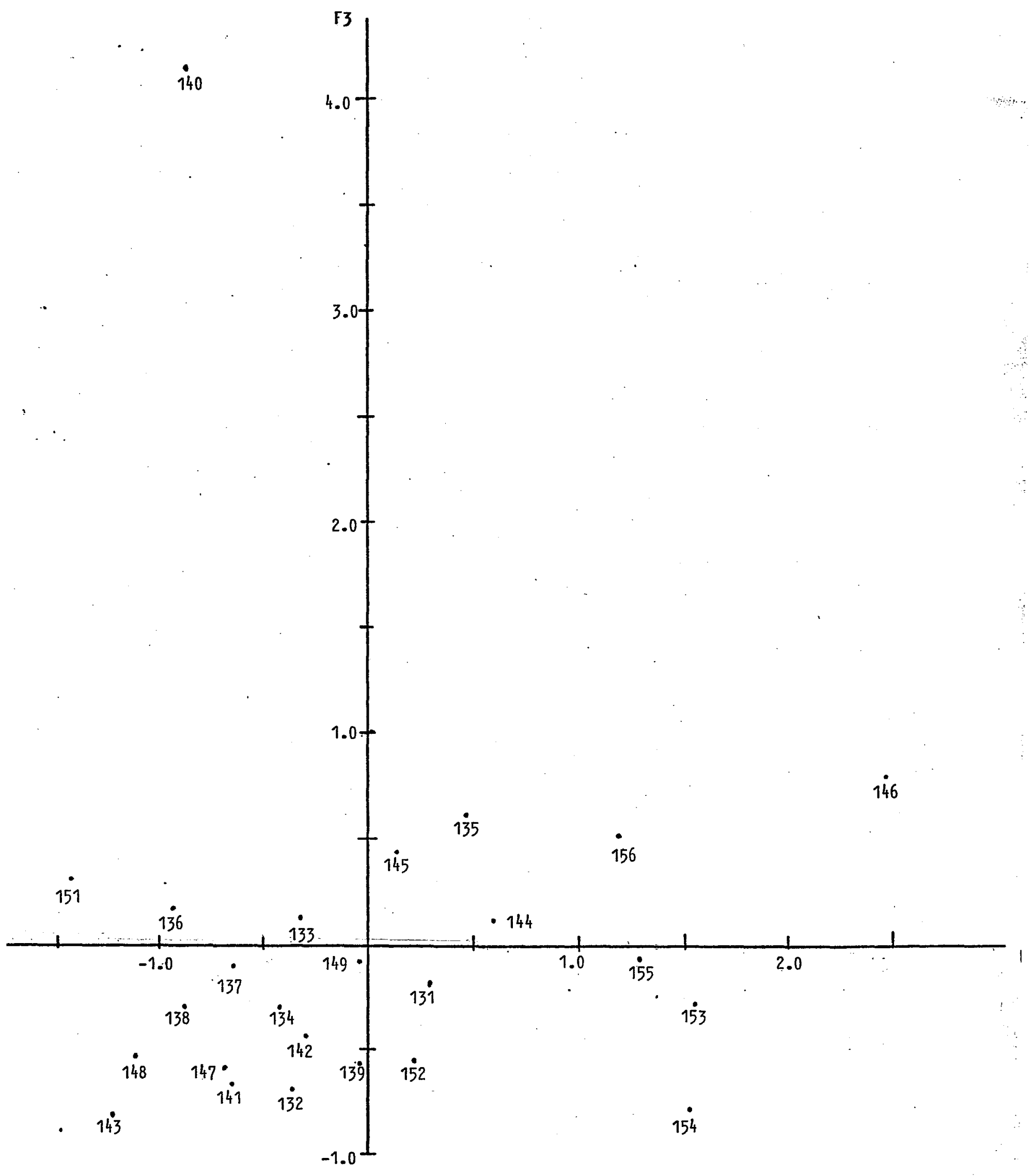

Fiqura 2: Valores dos fatores F1 e F3 por microrregiões do estado da Bahia. 


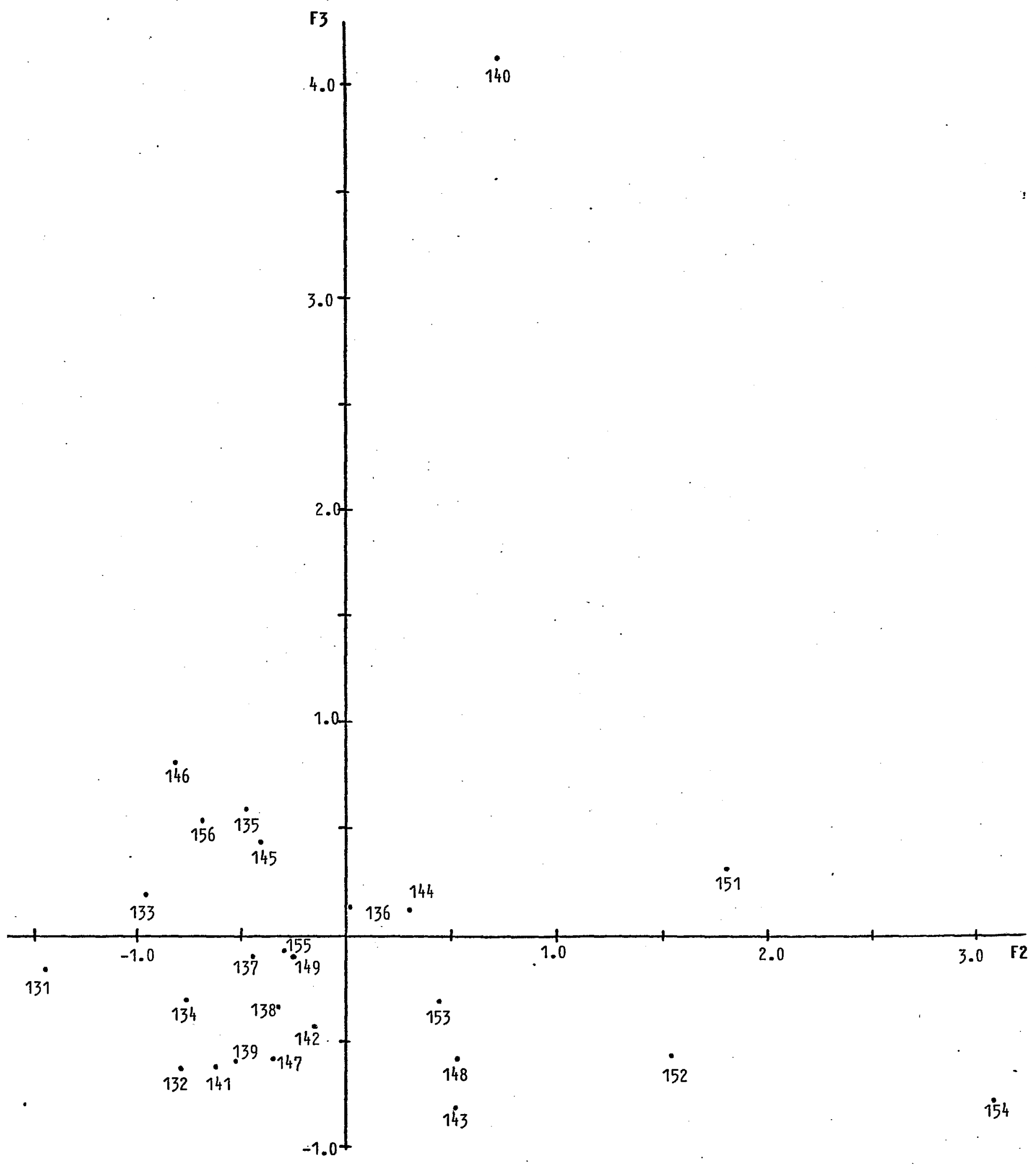

Fiqura 3 : Valores dos fatores F2 e F3 por microrregiões do estado da Bahia. 
Existem, entretanto, diferenças entre as microrregiões da zona Cacaueira. A mic̣rorregião Cacaueira é quase completamente especializada na prodụção de cacau, enquanto na de Tabuleiros de Valença, como visto anteriormente, além desta cultura têm valor da produção ponderável - cravo-da-índia, a mandioca, a borracha e a extração vegetal. (Ver Tabelas A.2.5 e A.2.6, no Anexo 2).

A própria observação das figuras mostra que em Tabuleiros de Valença os valores dos dois primeiros fatores, embora positivos, são bem menores que na microrregião vacaueira. \lém disso, nesta última microrregião os estabelecimentos são maiores em termos de área total.

De modo que, embora possam ser reunidas de um ponto de vista mais geral, com base nos valores dos 3 fatores, há uma diferenciação na zona Cacaueira. Por um lado, na microrregião Cacaueira predominam estabelecimentos de maior tamanho; com maior valor da produção por área explorada e por unidade de força de trabalho, que além de contratar empregados temporários nas épocas de colheita dispõem de elevada proporção de empregados permanentes. Do outro lado, em Tabuleiros de Valença os estabelecimentos têm menor área e obtêm menor valor da produção por área explorada e unidade de força de trabalho, utilizando uma proporção semelhante de trabalho temporário, mas com uma proporção inferior de empregados permanentes, destacando-se mais a força de trabalho do responsável e membros não-re- 
munerados de sua família. Essas diferenças, como veremos, repercutirão na distribuição de renda da PEA agrícola destas duas microrregiões.

o valor da produção de cacau também é importante em Encosta do Planalto da Conquista (153) e Interiorana do Extremo Sul da Bahia (155). Entretanto, essas microrregiões podem ser separadas das que se caracterizam por produzir cacau e reunidas com Pastoril de Itapetinga (146) e Litorânea do Extremo Sulda Bahia (156) para formar a Area de Gado-Lavoura Permanente.

Estas quatro microrregiões apresentam-se situadas entre o primeiro e guarto quadrante nas figuras 1 e 2, indicando valores altos para o fator F1 e valores em torno de zero para os outros dois fatores. Isto indica que - nível de modernização nesta área manifesta-se em elevadas escalas de empreendimento, alta produtividade da mão-de-obra e-importante uso-do trabalho assalariado mas não é muito intenso o uso da terra.

Nelas prevalecem grandes propriedades com alto valor da produção por unidade da força de trabalho utilizada mas que é pequeno em relação à área explorada. Esta peculiaridade, que implica pouco uso de força de trabalho, não só por área total, mas também por área explorada, pode ser atribuída à pecuária e também à extração vegetal, esta última na microrregião Litorânea do Extremo 
Sul da Bahia, onde o gado não é tão imporțante.

Outra microrregião em que : é ponderável 0 valor da produção de cacau é a de Jequié (144). Pela observação dos valores dos três fatores deveríamos reuní-la às de Planalto da Conquista (145) e Chapada Diamantina Setentrional (135). Acreditamos, entretanto, que devemos considerar separadamente esta última, por tratar-se de uma microrregião de lavoura temporária intensiva destacando - se a produção de feijão. Reunimos as outras duas para formar a Area de Policultura-Lavouras Permanentes (cacau e café).

A posição dessas microrregiões nas três figuras é bastante parecida à das que formam Area de Gado-Lavoura Permanente. Se diferenciam delas apenas pelo menor valor do fator Fl. Também são diferentes as composições do valor da produção. Na Area de Policultura-Lavouras Permanentes a pecuária não é tão importante e os estabelecimentos são bem menores, principalmente em área, mas também em valor dos bens e valor da produção. A produtividade da força de trabalho é menor, mas a prođução por área explorada é semelhante, de modo que, na área de Policultura-Lavoura Permanente é maior o emprego da força de trabalho por área explorada. Entretanto, a proporção do trabalho assalariado é menor. A policultura é praticada com maior proporção de mão-de-obra familiar, o que também terá implicações sobre a distribuição de renda. 
No segundo quadrante da figura 1 pode-se identificar um outro conjunto de microrregiōes com nível semelhante de modernização. Ele é formado por Recôncavo Baiano (151), Feira de Santana (143) e Agreste de Alagoinhas (148). Trata-se portanto de uma Area de Pecuária e Alimentos em torno da capital do estado.

Pelos valores observados dos fatores Fl e F2 poderíamos ter incluído neste grupo a microrregião Corredeiras de são Francisco (140). No entanto, ela foi excluída e considerada isoladamente porque como mostram as figuras 2 e 3, tem um valor do fator F3 atipicamente alto para o estado da Bahia.

O baixo valor de Fl e o alto valor de F2 nas microrregiões que formam a Área de Pecuária e Alimentos indicam que nelas usa-se intensivamente a terra (especialmente no Recôncavo Baiano), mas pratica-se uma agropecuária relativamente atrasada. As diferenças entre as microrregiões têm a ver com o tipo de produto. o gado é mais importante em Feira de Santana e Agreste de Alagoinhas, enquanto no Recôncavo pesa mais a produção de alimentos (mandioca, banana e laranja), e matérias-primas (cana-de-açúcar e fumol. Nos dois casos usa-se pouco trabalho assalariado. Os estabelecimentos são pequenos, notadamente em área, porque a terra é intensamente explorada pela força de trabalho das famílias. Eles, entretanto, não conseguem obter um valor de produção elevado, seja por área ou 
por unidade de força de trabalho empregada. Como veremos, isto também terá implicações sobre a distribuição de renda.

Do mesmo modo que Lacerda de Melo, reunimos as microregiões de Chapadões do Alto Rio Grande (131) e Baixo Médio são Francisco (133) para formar a Area de Incorporacão Recente à Agropecuária ou Área de Fronteira Agrícola da Bahia. De fato, elas têm em comum valores negativos do fator F2. Entretanto, em Chapadões do Alto Rio Grande é maior o valor do fator Fl, devido ao maior uso de trabaIho assalariado, bem como ao alto valor dos bens por unidade de força de trabalho e por estabelecimento, refletindo a maior importância da pecuária vis-à-vis às lavouras temporárias.

No Baixo Médio são Francisco, pelo contrário, o valor do fator Fl é negativo, mas o de F3 é positivo, por causa de suas áreas de irrigação com produtos de alto valor comercial. Isto explica porque nesta microrregião é maior o valor da produção por área explorada, mas não por estabejecimento nem por unidade de força de trabaIho utilizada. Os estabelecimentos possuem uma área média menor e usam mais força de trabalho por área explorada que em Chapadões do Alto Rio Grande, onde o Gado é criado em grandes estabelecimentos com pouca quantidade de força de trabalho em relação à área explorada, mas com maior proporção de empregados assalariados. 
As 10 microrregiões restantes, de um modo geral, podem ser caracterizadas como formando a Área de Agropecuária Atrasada, já gue os valores dos três fatores são baixos. Com exceção da microrregião Chapada da Diamantina Meridional (136), as demais localizam-se no terceiro quadrante em cada uma das três figuras.

Na microrregião Chapada da. Diamantina Meridional os valores dos fatores F2 e F3 são praticamente nulos e o de Fl bastante inferior a zero. Conclui-se então que a terra é usada com alguma intensidade, inclusive no sentido de tecnologia de ponta (utilização de trator e irrigação), mas o empreendimentos tem pequena escala e baixa produtividade da mão-de-obra e se usa pouco o trabalho assalariado. Pelo contrário, em Piemonte da Diamantina (139) e Iitoral Norte Baiano (149) o valor do fator Fl é próximo de zero. Na primeira microrregião isto se deve à importância relativa do valor da produção de aves e outros pequenos animais.

Nas microrregiões que claramente pertencem à Area de Agricultura Atrasada varia a composição do valor da produção. Em Sertão de Paulo Afonso (147) e Chapadões do Rio Corrente (132) predominam o gado e as lavouras de subsistência. Além do gado è das lavouras de subsistência, são importantes o algodão no Médio são Francisco (134) e na Serra Geral da Bahia (137), o agave em Serrinha (142) e Sertão de Canudos (141) e mamona e agave em Senhor do 
Bonfim (138).

Não obstante essas diferenças, todas as microrregiões tem valores negativos e muito baixos dos três fatores, indicando uso pouco intensivo do solo, pequena escala de empreendimento e baixa produtividade da mão-de-obra. Na maioria também é pequeno o uso do trabalho assalariado. Neste último aspecto há entretanto algumas exceções, notadamente Serrinha e Chapadões do Rio Corrente, onde é mais importante o uso do trabalho assalariado.

Restam alguns comentários sobre as duas microrregiões que não puderam ser agrupadas com outras, devendo ser consideradas como espaços característicos e separados. Corredeiras de são Francisco é muito heterogênea, destacando-se, de um lado, uma lavoura intensiva, irrigada, de produtos de alto valor comercial, na proximidade do Rio são Francisco, e de outro, uma pecuária extensiva de animais de grande e médio porte na caatinga. Na média resulta um baixo valor para o fator Fl e elevados valores para os fatores F2 e F3.

Na Chapada Diamantina Setentrional, pelo contrário, Fl é relativamente elevado, refletindo mais fortemente a escala do empreendimento e o uso de trabalho assalariado, e menos fortemente a produtividade da mão-de-obra. Entretanto, o valor de F2 é baixo, indicando menor intensidade de exploração da terra, apesar de se praticar uma lavoura temporária relativamente mecanizada, principalmente na produ- 
ção de feijão em Irecê. No entanto, a menor heterogeneidade das situações nesta última microrregião se refletirá na distribuição de renda.

- quadro seguinte e o Mapa 3 sintetizam a regionalização proposta: 
CARACTERIZAÇAO REgIONAL DA BAHIA, 1980

\begin{tabular}{|c|c|c|c|}
\hline IIPO DE & MICRORREGIOES & PROOUIOS E/OO AIIVIDADE & PADRAO AGRICOLA DOKIMANIE \\
\hline ESPAÇO AGRARIO & & AGEOPECOARIA DOMIMANIE & \\
\hline 1 Cacaueira & $\begin{array}{l}\text { Cacaueira (154) } \\
\text { Tabuleiros de Valenga (752) }\end{array}$ & $\begin{array}{l}\text { cacau } \\
\text { cacau, cravo-da-índia, mandioca, borracha, extrą̧ão } \\
\text { vegetal }\end{array}$ & 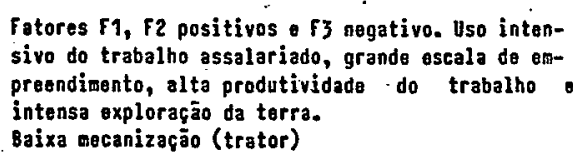 \\
\hline
\end{tabular}

i de Gado-

usra Permaneate

I de Policultura

youras Persanen-

1e Pecuária-

imentos.

Ie Iacorporiçäa
ente i
opecoária

Chapadōes do Alto Rio Grande (131)

Baixo Médio São Francisco (133)

a de Agropecuária asada

a dẹ Lavoura igada-pectária onsiva

Pastoril de Itapetinga (146)

Jequié (144)

Planalto da Conquista (145)

Feira de Santana (143)

Agreste de Alagoinhas (148)

Recôncavo Baiane (751)

Piemonte da Diamantina (139)

Litoral Morte Baiano (149)

Sertão de Paulo Afonso (14?)

Chapadōes do Rio Corrente (132)

Mìdio Säo francisco (13,4)

Serrinha (142)

Sertão de Canudos (141)

Senhor do Bonfin (138)

Corredeiras do São Francisco (140)
Encosta do Planalto da Conquista (153) cacau, animais de grande porte

Interiorana do Extremo Sul da Bahia(155) anjmais de grande porte, cacau e feijāo

animais de grande porte, café

Litorânea do Extremo Sul da Bahia (156)

animais de grande porte, cacau, feijãa, extrą̧ão vegetal

animais de grande porte, cacau, café, mandioca, feijāo

Fator $\mathrm{F1}$ o $\mathrm{f3}$ positivos, $\mathrm{F2}$ en torno de zaro. Uso intensivo do trabalho assalariado; grande escala de ompreendinento, alta produtividade do trabalho - uso intensivo do solo ("tecnologia de pontan.) Uso extensivo da terra.

Chapada dè Diamantina Meridional(136)

Sorra Geral da Bahia (137)

Chapada Diamantina Setentrional (135)

Fator 19 positivo, 72 of 3 on torno de zero. Uso intensivo do trabalho assalariado, grande escala de empreendimento e alta produtividade do trabalho. Uso extensivo da terra.

Fator 22 positivo,' $F 1$ negativo a 83 en torno de zero. Uso intensivo da terra, pouco uso do trabalho assalariado, pequena escala de emproendimento, . baixa produtividade do trabalbo

- Regular uso da "tecrologia de ponta"

animais de grande porte, pequenos animais, aves, cana-de-açúcar, banana o laranja

Fator 72 negativo, 11 \& 13 entre -0.5 e 0.5 .

animais de grande porte, feijāo, milho, arroz animais de grande médio porte, feijão, mandioca, -ilho, cobola

Regular uso de trabalho assalariado, escala e produtividade do trabalho. Pequena intensidade de uso do solo o regular "tecnologia de ponta"

arimais de grande porte, feijạa, café, ailho, mandioca anipais de grande porte, mandioca, agave e feijāo

F1, F2 — F3 negativos. Baixo uso de trabalho assalariado, pequena escala, baixa produtividade do trabalho o pouco uso da terra.

animais de grande porte, mandioca, coco-da-8ahia, ayes oequenos animais

animais de grande e médio porte, feijãó, palma, aves o pequenos animais

aniamis de grande o médio porte, fei jāo, milho

aniwais de grande porte e nédio porte, feijão, milho, algotāo

animais de grande aédio porte, fei jäo, milho, algodāo

aniwais de grande porte, agave

aniaais de grande ò médio porte, agave, foi jão, andioca, -xtraģäo vegetal

animais de grande o zédio porte, fei jāo, mandioca, aanona - agave

animais de grande e aédio porte, fei jāo, cebola

P1 negativo, 12 positivo o 13 positivo o auito al to Pouco uso de trabalho assalariado, pequena esczla e baixa produtividade do trabalho. Pouca exploração de terra, alto uso de teciologia de ponta (necanização: irrigaçäo)

51. 53 positivo, 52 negativo. Grande escala, alta produtividade da eão-do-obra. Ho intensivo do trabalhe assalariado, alta tecnologia de ponta o baixa exploraf̧äo do solo. 
MAP̉ 3 Bahia - Caracterização Regional

a partir dos fatores, 1980

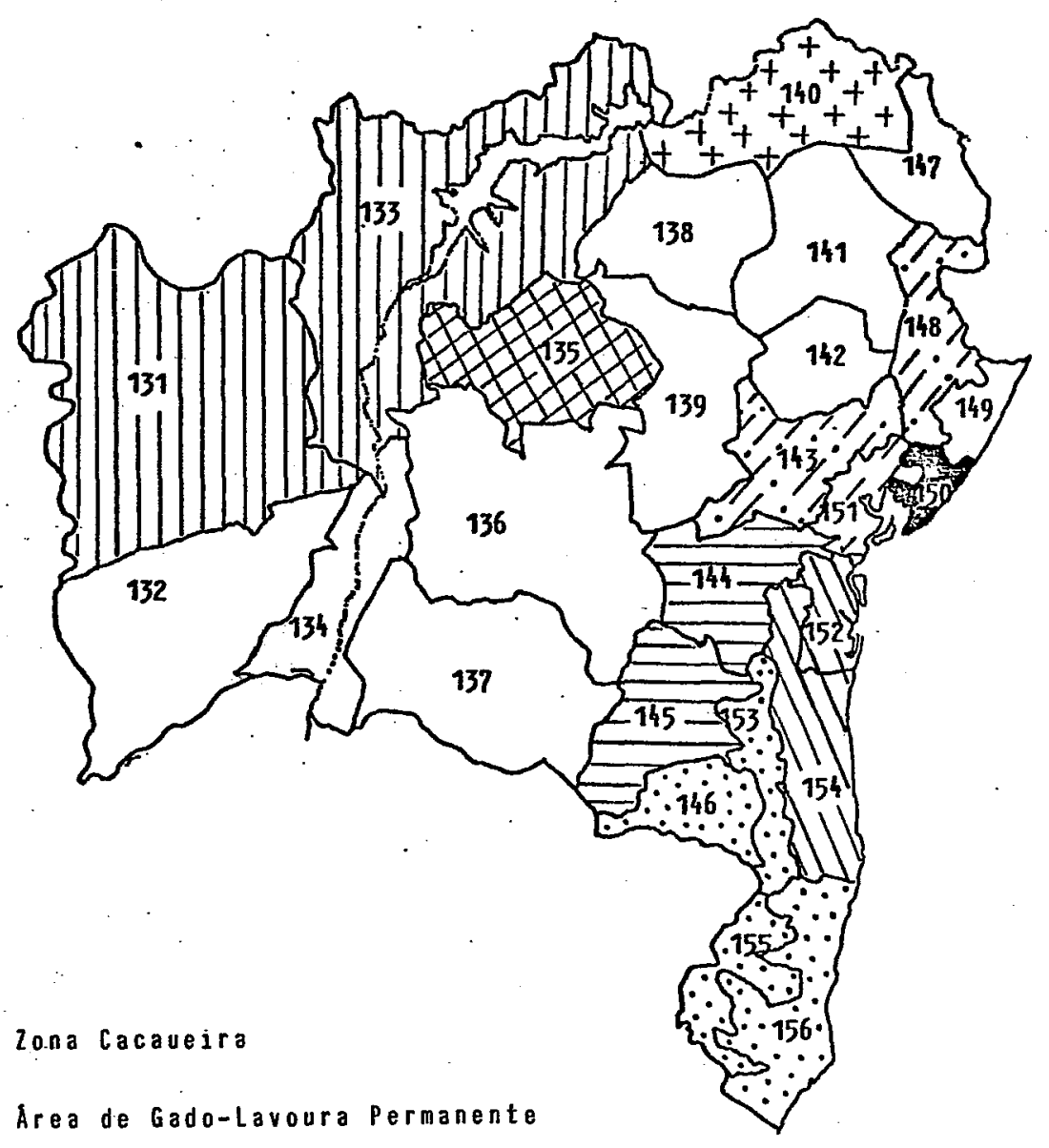

Área de Policultura - La wouras Permanentes

[i] Area de Pecuária - Alimentos

पIII Area de Incorporação Recente à Agropecuária

- Area da Agropecuária Atrasada

$\left[+_{+}^{+}+\right.$Lavoura Irrigada - Pecuária Extensiva

QXX Lavoura Intensiva

Hão Classificada 


\title{
4.4. Relações entre Modernização e Distribuição de Renda no Setor Agropecuário em 1980
}

\begin{abstract}
Uma visualização preliminar das relações entre modernização e distribuição de renda no setor agropecuário em 1980 pode ser obtida através das diferentes áreas de agropecuária identificadas no item anterior. Observam-se diferentes perfis distributivos, e as diferenças podem ser associadas às características da produção e da estrutura agrária prevalecentes em cada uma das áreas (ver Tabela 10).

Numa apreciação global, nota-se que do ponto
\end{abstract} de vista da renda média, existem 10 microrregiões com renda média da população economicamente ativa (PEA) significativamente maior que o salário mínimo. Elas conformam 5 diferentes grandes áreas de produção agropecuária. Na Zona Cacaueira, o relativamente elevado nível de renda média ocorre com um grau de pobreza relativamente baixo. Há entretanto, uma diferença considerável no que diz respeito à desigualdade de renda nas duas microrregiões que compõem esta área de prođução agropecuária. Essas diferenças estão relacionadas com diferentes composições da força de trabalho. Em Tabuleiros de Valença, onde a desigualdade de renda é menor, predomina o trabalho não-assalariado. Na miçrorregião $\mathrm{Ca}-$ caueira é bem menor a importância do trabalho não-assalariado, destacando-se a dos empregados permanentes. Em ambas 
abela $10: \quad$ Perfis Distributivos e Composição da Força de Trabalho, Bahia, 1980.

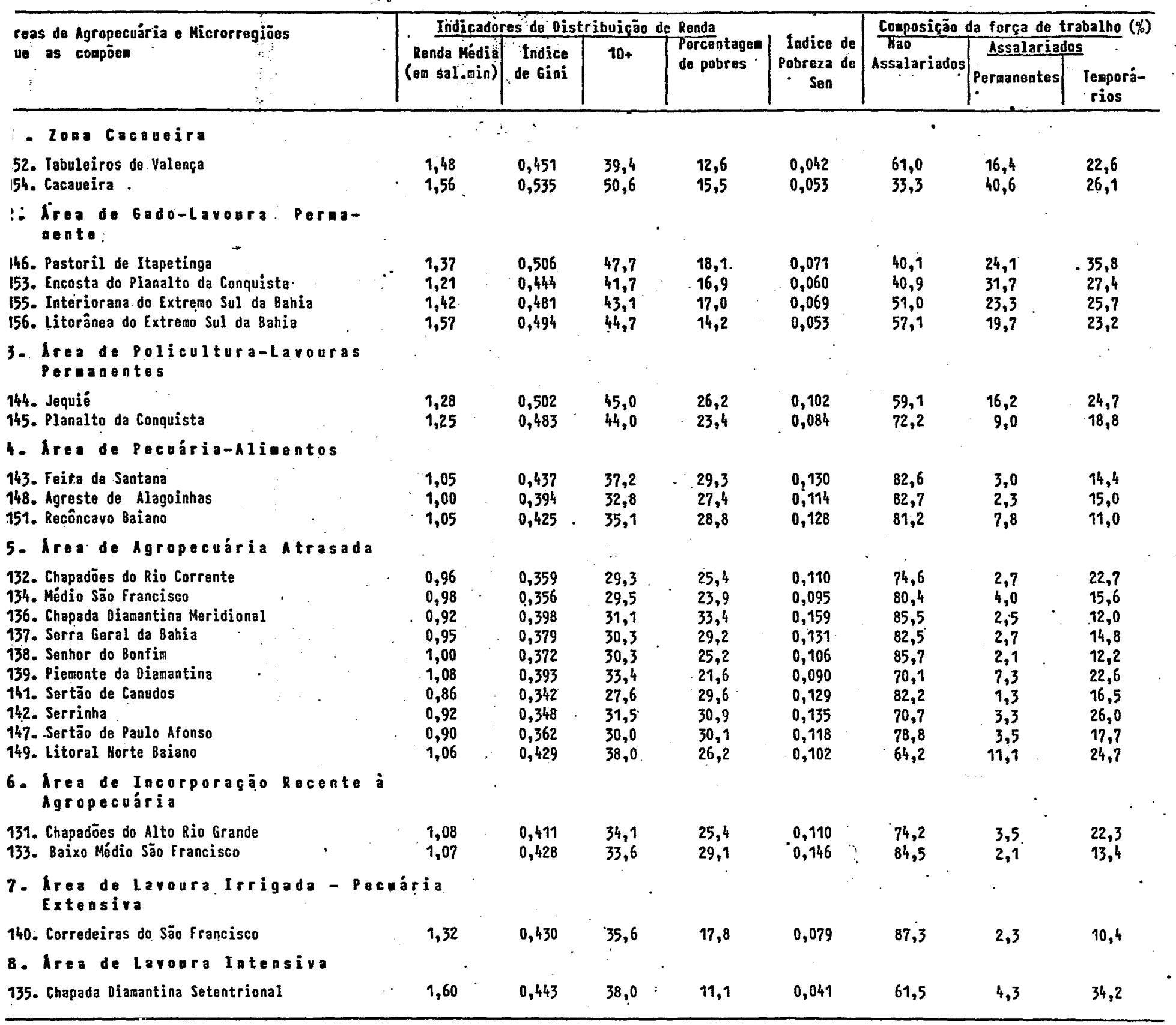

Fonto: Tabulaçōes Especiais sobre distribuiçäo de renda para 1980. Ceriza Demográfico de 1980. 
não é Ġsprezível o uso de empregados temporários.

Na Area de Gado-Lavoura Permanente, a pobreza (proporção de pobres e ínđice de sen) também è relativamente baixa e a desigualdade de renda é elevada. A composição da força de trabalho parece refletir o elevado peso de grandes estabelecimentos que usam trabalho assalariado, tanto de empregados permanentes quanto de temporários.

Na Area de Policultura-Iavouras Permanentes, - grau de pobreza é um pouco maior e a desigualdade de renda também é elevada. A composição da mão-de-obra é diferente daquela das duas áreas já consideradas, havendo uma proporção significativamente maior de não-assalariados. Podemos vincular este fato com o maior grau de pobreza prevalecente nesta área de produção agropecuária, o que contrasta com o observado na microrregião de Tabuleiros de Valença, na Área Cacaueira. Possivelmente uma alta proporção de não-assalariados, reflete a importância relativa do emprego na pequena produção agrícola. Tudo indica que em Tabuleiros de Valença na pequena. produção agrícola há ı̣m equilíbrio maior entre a produção de alimentos para subsistência do agricultor e a produção de lavouras permanentes comerciais.

Nas outras duas áreas de maior renda média (Lavoura Irrigada-Pecuária Extensiva e Lavoura Intensiva), o nível de pobreza é também baixo e elevada a proporção de não-assalariados. De modo análogo ao ocorrido em Tabuleiros: de Valença (só que agora com lavoura temporária), há uma me- 
Ihor combinação da pequena produção de alimentos para subsistência com a de produtos comerciais. Isto parece refletir-se nessas três microrregiões (Tabuleiros de Valença, Corredeiras do São Francisco e Chapada Diamantina Setentrional) em menores índices de pobreza combinados com menor desigualdade de renda. Os índices de desigualdade de renda nessas três áreas assemelham-se aos valores observados para as microrregiões de baixo nível de renda média.

Entre as microrregiões de baixo nível de renda distinguem-se pelo menos três situações diferentes, que correspondem às áreas de: Pecuária-Alimentos, Fronteira de Ocupação Recente e Agropecuária Atrasada. Nessas três áreas, - grau de pobreza é elevado, predomina o trabalho não-assalariado e a desigualdade de renda é baixa. A pobreza provavelmente deriva das condições da pequena produção de subsistência e os baixos níveis e desigualdade de renda expressam a debilidade global da produção agropecuária dessas áreas. Há algumas exceções em que o quađro não é tão dramático, com renda média não inferior ao salário mínimo e menor desigualdade, principalmente em algunas microrregiões que compõem a área de agropecuária atrasada.

Em resumo, existe na Bahia um "leque" de situações que correspondem a diferentes padrões de modernização e distribuição de renda. Num extremo estão as microrregiōes de agropecuária atrasada em que a pobreza é generalizada, manisfestando-se em baixos níveis e baixa desigual- 
dade de renda. No outro extremo encontram-se parte da Area Cacaueira e a Area de Gado-Lavoura Permanente, onde a pobreza não é grande, a renda média é elevada mas prevalece grande desigualdade. Entre esses dois extremos há uma variedade de situações. Na Área de Policultura-Lavouras Permanentes a coexistência de pequena produção precária de subsistência com lavouras comerciais de alta produtividade faz com que sejam elevados os índices de pobreza e a renda média, sendo portanto também elevada a desigualdade de renda.

As Áreas de Pecuária-Alimentos e de Incorporação Recente de Fronteira têm as mesmas condições de precariedade da pequena produção de subsistência, sem uma agropecuária com produtividade suficiente para provocar uma desigualdade de renda tão elevada. Por esse motivo, são maiores os índices de pobreza e menores o nível e desigualdade de renda.

Finalmente, numa parte da zona Cacaueira e nas Areas de Lavoura Irrigida- Pecuária Extensiva e Lavoura Intensiva, a prosperidade comercial da pequena produção faz com que não somente sejam pequenos os índices de pobreza mas também que o alto nível de renda média não corresponda a uma grande desigualdade de renda. Estas últimas, na verdade, configuram exceções à regra, também verificada na Bahia, em que maiores graus de modernização correspondem não só a menór pobreza e maior nível de renda média mas 
também a maior desigualdade de renda.

$$
\text { A existência dessa relação para o conjunto }
$$
de microrregiões da Bahia pode ser percebida através de uma análise de regressão.

As tabelas 11 e 12 mostram os resultados das regreșões múltiplas entre os vários indicadores da distribuição da :renda (renda média, índice de Gini, porcentagem de renda dos $10 \%$ mais ricos, porcentagem de pobres e índice de pobreza de sen) e os fatores de modernização agrícola: Utilizaram-se dois modelos de regressão (iinear e quadrática) e as observações foram ponderadas pela população economicamente ativa.

o modelo quadrático não se mostrou mais apropriado que o modelo linear. Embora os coeficientes de determinação obtidos sejam ligeiramente superiores, os coeficientes dos termos quađráticos não são significativos. Os coeficientes dos termos lineares têm o mesmo sinal nos dois modelos e, de um modo geral, quando um deles é significativo num dos lodelos também o é no outro. Em função disso, discutiremos apenas os resultados das regressões 1 ineares.

No modelo linear, os coeficientes de determinação são maiores para as regressões das variáveis que expressam o nível e desigualdade de renda (renda média, índice de Gini e porcentagem de renda dos $10 \%$ mais ricos) do 


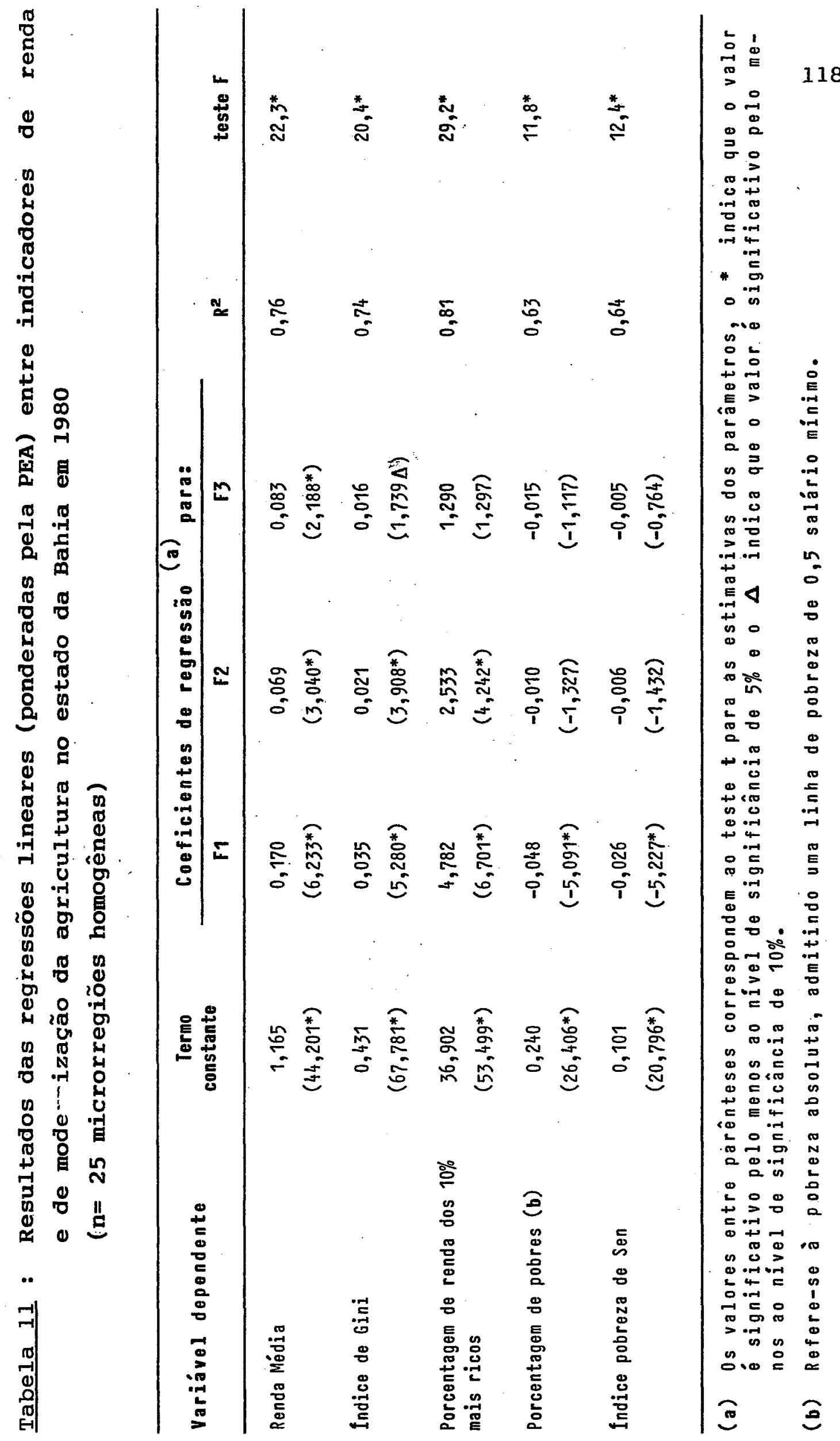




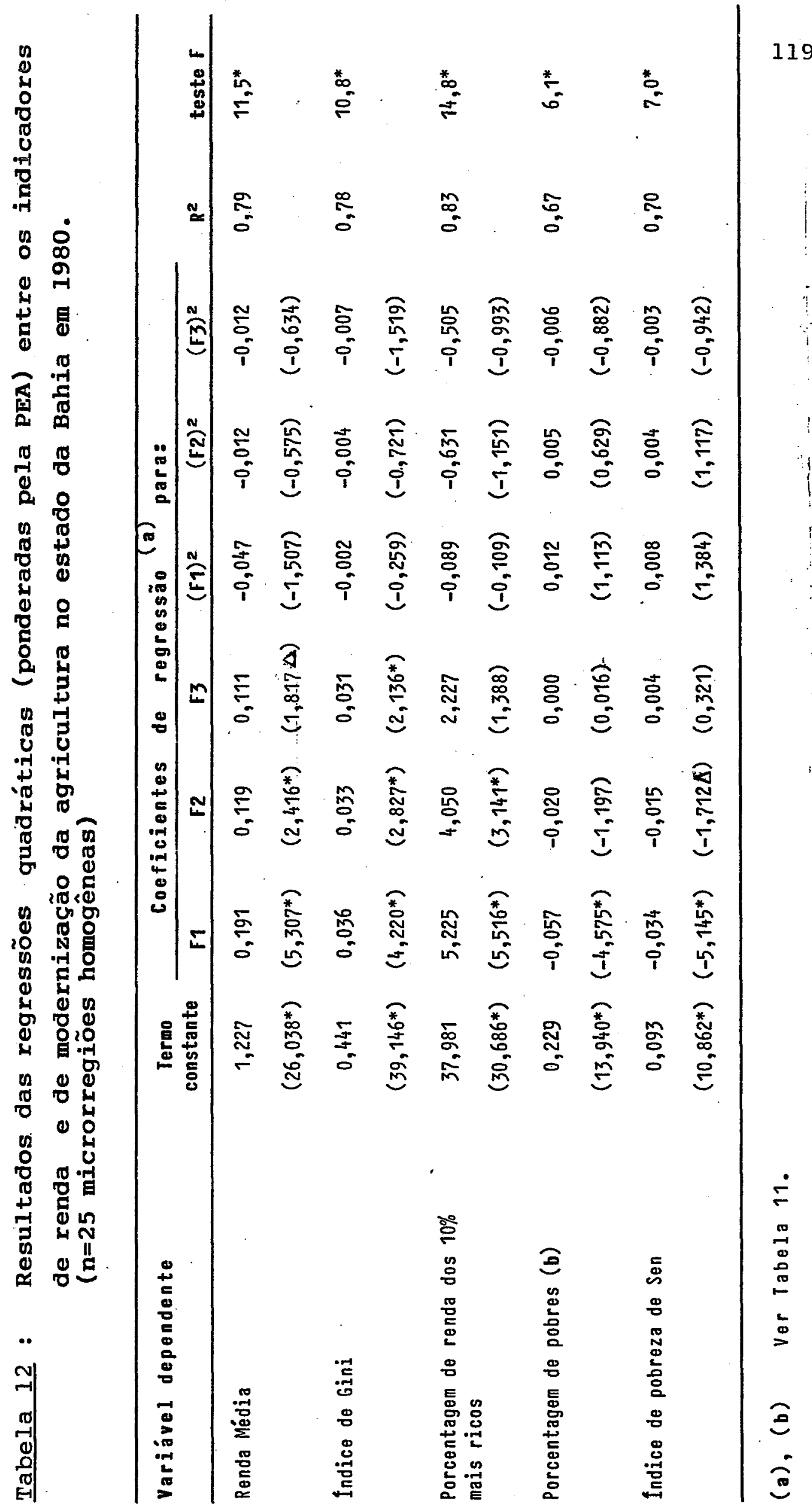


que para as regressões das variáveis que expressam a pobreza (proporção de pobres e índice de pobreza de Sen). Isto quer dizer que uma proporção um pouco menor da dispersão das variáveis indicadoras de pobreza é explicada pelos três fatores de modernização.

A observação dos coeficientes dos fatores de modernização nas cinco regressões lineares mostram que há uma relação positiva dos três fatores com os indicadores de nível e desigualdade de renda e uma relação negativa dos três fatores com os indicadores de pobreza. Também se observa que só os coeficientes do primeiro fator são significativame nte diferentes de zero nas cinco regressões. o efeito do segundo fator é significativo somente nas regressões das variáveis que expressam o nível e a desigualdade de renda. E o terceiro fator mostra influência estatisticamente significativa apenas na regressão da renda média.

Em resumo, a renda média está diretamente relacionada com os três fatores da modernização enquanto que os indicadores de desigualdade de renda estão também diretamente relacionados com os dois primeiros fatores e os indicadores de pobreza estão inversamente relacionados somente com o primeiro fator.

Concluindo, a combinação da alta intensidade de uso do trabalho assalariado, escala de empreendimento e produtividade do trabalho (FI) afeta positivamente 
- nível médio e a desigualdade de renda das microrregiões e negativamente os indicadores de pobreza. o fator representativo da intensidade de exploração da terra (F2) afeta positivamente o nível e a desigualdade de renda mas não tem um efeito significativo sobre a pobreza. Finalmente, o fator gue expressa um uso intensivo do solo pela "tecnologia de ponta" (F3), só tem um efeito significativo sobre a renda média.

Assim, mesmo no estado da Bahia, onde são amplamente difundidos os baixos níveis de renda na agropecuária, nota-se nas diferenças entre microrregiões a influência do grau de modernização sobre a pobreza, nível e desigualdade de renda. A influência é marcante principalmente nos aspectos da modernização que têm a ver com produtividade, escala e uso de trabalho assalariado. As microrregiões com maior grau de modernização, em geral, apresentam menor pobreza e maior nível e desigualdade de renda. 


\section{RESUMO E CONCLUSÕES}

Um primeiro resultado do trabalho foi mostrar que a aplicação da metodologia utilizada por HOFFMANN e AGEYAMA (1985) no estudo da relação entre modernização e distribuição de renda no Brasil, tendo como unidade de análise os estados da federação, leva a resultados que devem ser interpretados com cautela quando se trata de um determinado estado em que a unidade de análise são as suas microrregiões. Mas, mesmo assim, é confirmada a tese geral proposta pelos autores, no sentido de que existe uma associação direta entre o grau de modernização da agricultura e - nível e desigualdade da renda agrícola, além do que, maiores níveis de modernização tendem a estar associados com menores níveis de pobreza rural.

A especialização das microrregiões por produto coloca dificuldades à interpretação do significado das variáveis utilizadas para medir o grau de modernização da produção agropecuária. As diferenças entre microrregiões no valor dessas variáveis podem não corresponder exatamente a distinções no grau de modernização da produção. 
A própria medida do que seja a "modernização", através de indicadores onde entram aspectos técnicos e valores monetários, é bem mais objetiva quando há uma dada gama de produtos comuns às áreas analisadas. Nessas condições as diferenças no valor das variáveis expressariam, exclusivamente, distinções no grau de modernizaçãol ${ }^{1}$ Entretanto, a especialização da produção das microrregiões viola essa condição e, então, as diferenças no valor das variáveis podem estar refletindo também a diversidade das estruturas de produção ao nível de produtos, além das diferenças do grau de modernização propriamente dito.

De fato, o próprio significado de cada uma das variáveis usadas para medir o grau de modernização varia de um produto para outro ${ }^{2}$. Isto faz com gue nem sempre se verifiquem correlações teoricamente esperadas entre variáveis que medem diferentes aspectos da modernização. Além disso, pode até mesmo ficar difícil a interpretação do significado econômico quando as correlações se apresentam e são significativas.

Assim, por exemplo, um dos sintomas de modernização da produção agropecuária é um elevado grau de intensidade na exploração do solo, que se manifesta de diferentes maneiras. Em particular, pode se distinguir, de

1 É claro que há indicadores gerais, como o uso de trabaTho assalariado ou as despesas com adubos e defensivos, que são inequivocamente indicadores de modernização, independentemente do tipo de produto dominante.

2 É o caso, por exemplo, da baixa utilização de tratores na lavoura de cacau. A forma de cultivo adotada (sombreamento com mata natural) impede o uso de trator, mesmo que o grau de modernização em geral seja alto nessa cultura. 
um lado, a proporção da área total que é efetivamente trabalhada e, de outro, o grau e as formas como é feita a exploração da terra.

Usamos diferentes variáveis para captar cada um desses aspectos. da intensidade de exploração do solo. o valor total dos bens por área dos estabelecimentos foi usado como "proxy" da intensidade de capital fixo do empreendimento agropecuário. o total de despesas por área explorada, por sua vez é "proxy" da intensidade de capital cí culante. Finalmente, o valor da produção por área explorada mede a intensidade do uso do solo a partir de seus resultados.

Para as microrregiões do estado da Bahia, as três variáveis anteriores, tal como esperado, estão estreitamente correlacionadas. Por outro lado, não há correlação significativa entre elas e a proporção da área total que é efetivamente trabalhada.

As composições da produção, dos bens e das despesas também são heterogêneas. Por exemplo, no caso dos bens, incluem-se desde prédios residenciais que nada têm a ver com modernização, passando por lavouras permanentes e animais de criação e de trabalho que por si mesmos pouco significam em termos de atividade moderna, até tratores, equipamentos e estoques de insumos químicos que são considerados típicos da agricultura moderna. A composição desses bens pode variar muito de uma microrregião a outra em função não tanto do grau de modernização quanto dos tipos 
de produtos proininantes.

$$
\text { Ȧssim, não há correlação estatisticamente }
$$

significativa entre, de um lado, os valores dos bens por unidade de área total e das despesas e produção por área explorada e, de outro, o número de tratores por área trabaIhada, o número de bovinos por área de pastagens;i. a proporção dos estabelecimentos que usam adubo orgânico $\therefore$ e a proporção irrigada de área total.

Entretanto, a ausência dessas correlações, longe de negar a proposição de que um dos aspectos principais da modernização agrícola é a intensificação do uso do solo, serve como ilustração da hetérogeneidade de usos que se dá ao solo entre microrregiões da Bahia. Assim, por exemplo, somente em áreas đe lavoura temporária intensiva, como nas zonas de irrigação e no município de Irecê, tem maior significado o uso de tratores, enquanto nas áreas de cacau e gado melhorado são bem maiores os valores de bens, despesas e produção por área total ou explorada.

Outros aspectos da modernização são a escala do empreendimento e a produtividade do trabalho. Usamos como aproximação da produtividade do trabalho a variável valor da produção por equivalente-homem, enquanto a escala econômica do empreendimento foi expressa pelo valor dos bens e da produção por estabelecimento. Na Bahia, essas variáveis estão correlacionadas mas, refletindo a diversidade de formas de uso do solo, a produtividade do trabalho 
parece menos dependente da mecanização (tratorização) do que de outros fatores mais gerais associados à atividade agropecuária, notađamente a intensidade de exploração da terra e sobretudo o volume de capital fixo aplicado.

Finalmente, o assalariamento da força de trabalho é um indicador importante de modernização. Embora a importância relativa dos diversos tipos de assalariado (empregado permanente ou temporário) varie entre pecuária, lavouras permanentes e temporárias, observa-se que, de um modo geral, onde é alta a proporção de assalariados na força de trabalho total também é elevada a de empregados temporários.

No que diz respeito à distribuição da renda, a Bahia é o estado do Nordeste com maior nível médio e desigual dade de renda da PEA na agropecuária. Não obstante, situa-se abaixo da média do país nesses dois aspectos da distribuição.

Existem na Bahia grandes diferenças de pobreza, nível e desigualdade de renda entre microrregiões. As maiores diferenças dizem respeito à pobreza, observando-se uma correlação direta entre renda média e desigualdade e uma correlação inversa entre renda média e pobreza. Não obstante, apesar das diferenças entre microrregiões, em todas elas prevalece um nível de renda muito baixo para a maioria da população.

Tendo constatado as diferenças entre microrregiões, passamos a analisar a relação entre as variáveis 
que expressàn a wổernização da produção agropecuária e as que refletem : aracterísticas da distribuição de renda da população agropecuário. Um passo prévió foi a realização da análise dos componentes principais das variáveis que exprimem a modernização.

A análise dos componentes principais permitiu destacar três fatores que respondem por $3 / 4$ da variância total dos dados sobre modernização. o primeiro fator está estreitamente relacionado com as variáveis que expressam a importância do trabalho assalariado, a escala dos empreendimentos e a produtividade do trabalho. Com o segundo fator estão associadas as variáveis que expressam intensidade de exploração da terra. Porém, na Bahia, e talvez em todo o Nordeste, intensidade de exploração da terra nem sempre quer dizer mecanização, irrigação: e pecuária intensiva, que são os aspectos da capitalização da agropecuária vinculados correntementè à modeirnização. As variáveis que captam esses aspectos específicos da intensidade de exploração do solo estão associados com o terceiro fator.

Em resumo, os três fatores permitem isolar três aspectos diferentes da modernização da atividade agropecuária na Bahia. Eles foram utilizados, em primeiro lugar, para regionalizar a atividade agropecuária deste estado, visando uma primeira aproximação à análise das re- 
lações entre as peculiaridades da produção e as característinas da distribuição de renda. Posteriormente, foram Eeị unálises de regressão entre cada uma das característiras ta distribuição de renda e os fatores de 'modernização.

A regionalização obtida teve o propósito exclusivo de servir de instrumento auxiliàr para uma discussão preliminar da relação entre modernização e distribuição de renda na agropecuária baiana. Em um estudo cuja finalidade principal fosse fazer uma regionalização 'sócio-econômica da Bahia, seria necessário considerar outras variáveis, como, por exemplo, as características demográficas, o grau de urbanização e o grau de industrialização de cada microrregião.

Foram identificadas oito grandes áreas de produção agropecuária no estado da Bahia. Esta classificação das microrregiões a partir dos valores dos três fatores de modernização ajudou a explicar a existência de um leque de situações diferentes a que corresponde determinada relação entre modernização e distribuição de renda.

Nùm extremo estão as microrregiões de agropecuária atrasada, em que a pobreza é generalizada e são . bàixos o nível e a desigualdade da renda. No outro extremo estão uma parte da Area Cacaueira e toda a Area de Gado - Lavoura Permanente, onde a pobreza não é tão grande, a renda média é relativamente alta e prevalece grande desigualdade. 
Entre os extremos, há diversas

situações intermediárias. Na Area de Policultura - Lavouras Permanentes combina-se uma precária pequena produção de subsistência com grandes lavouras comerciais de alta produtividade, fazendo que seja grande a pobreza mas com renda média relativamente alta e enorme desigualdade. Na área de Pecuária-Alimentos e na área de Incorporação Recente à Agropecuária observam-se as mesmas condições de precariedade da pequena produção de subsistência, sem que simultaneamente exista uma agropecuária comercial com produtividade suficiente para provocar uma desigualdade semelhante à da Area de Policultura-Lavouras Permanentes. Em conseqüência, nas áreas de Pecuária-Alimentos e de Incorporação Recenté à Agropecuária, a pobreza é maior e são menores o nível e desigualdade da renda.

Finalmente, em parte da Zona Cacaueira e nas áreas de Lavoura Irrigada-Pecuária Extensiva e de Iavoura Intensiva a prosperidade comercial da "pequena produção" faz com que não somente a pobreza não seja tão grande:como também que a alta renda média observada não' seja acompanhada de tão grande desigualdade. Essas zonas de produção, na verdade, são exceções à regra. Aí, provavelmente, encontra-se uma pequena produção mais tecnificada, em meThores condições do que a pequena produção do minifúndio típico do Nordeste. 
A tese de que a modernização se associa a maiores níveis de renda, menor pobreza e maior desigualdade é confirmada pela análise de regressão entre cada uma das variáveis que expressam as características da distribuição da renda e os três fiatores de modernização. A intensidade de uso do trabalho assalariado, a escala dos empreendimentos e a produtividade do trabalho, representados pelo primeiro fator (F1), afetam positivamente o nível e a desigualdade de renda das microrregiões e negativamente os indicadores de pobreza. Por sua vez, a intensidade de exploração da terra, representada pélo segundo fator (F2), afeta positivamente o nível e desigualdade da renda mas não tem efeitos significativos sobre a pobreza. Finalmente, a intensidade de uso do solo através da utilização de "tecnologia de ponta" só afeta a renda média mas não a desigualdade de renda e a pobreza.

Lembrando o apontado na discussão da relação entre modernização e distribuição de renda através da regionalização das microrregiões, podemos ter uma idéia,/ mesmo que imprecisa, das razões pelas quais a intensidacie de exploração da terra não afeta a pobreza e a "tecnologial de ponta" só afeta a renda média. No primeiro caso, microrregiões como as que formam as áreas de Pecuária-Alimentos e Policultura-Lavouras Permanentes têm alta intensidade de uso do solo mas nelas é grande a pobreza. Nessas áreas o peso da mão-de-obra não-assalariada é elevado,. indicando 
provavelmente a presença dominante da pequena produção precária que, apesar de explorar intensivamente a terra, não tem condições de melhorar seus níveis de renda. Não temos os dados necessários para o cabal esclarecimento dessa questão, mas algumas informações indiretas apontam nessa direção. Como se pode observar na Tabela A2.7 do Anexo 2, as microrregiões onde é grande a pobreza e simultaneamente é elevada a proporção da mão-de-obra não assalariada, é muito alta a proporção de estabelecimentos muito pequenos (de menos de 10 hectares): Pode-se ilustrar esse fato, por exemplo, com as microrregiões Baixo Médio são Francisco, Chapada da Diamantina Meridional; Feira de Santana e Recôncavo Baiano, todas com mais de $80 \%$ de não-assalariados, em torno de $30 \%$ de pobres e mais de $60 \%$ dos estabelecimentos com menos de 10 hectares, dando a entender a existência de uma associação entre presença da pequena produção familiar e extensão da pobreza. No segundo caso, as poucas microrregiões em que pesa a "tecnologia de ponta" (Ạrea de Lavoura Irrigada e Iavoura Intensiva) não têm tanta desigualdade de renda, apesar das altas rendas médias.

Em síntese, mesmo na Bahia, onde é difundidu o baixo nível de renda na agropecuária, notam-se diferenças entre as microrregiões que traduzem a influência da modernização sobre pobreza, nível e desigualdade de renda. A pobreza parece ter suas raízes principalmente nas condições precárias da pequena prođução de subsistência e nos salários baixos. Quando a "pequena prođução" está voltada pa- 
ra lavouras de alto valor comercial (Corredeiras do são Fran cisco e Chapada Diamantina Setentrional) a pobreza é menor e não há tanta desigualdade de renda como a observada nas áreas da grande produção de cacau, gado-lavouras permanentes e policultura-lavouras permanentes. Por outro lado, devido à alta produtividade, apesar de constituírem hoje áreas de atração de população, aquelas duas microrregiões não se companam, em termos de densidade demográfica, com as áreas da Bahia onde prolifera a precária pequena produção de subsistência. Portanto, o "exemplo" constituído pelas MRH Corredeiras do são Francisco e Chapada Diamantina Setentrional não poderia ser utilizado como modelo para solução geral dos problemas de emprego e distribuição de renda na agropecuária baiana.

Não obstante, entre 1970 e 1980 mudou radicalmente a importância relativa da pequena produção e do assalariamento da mão-de-obra na explicação da incidência da pobreza na agricultura do estado da Bahia. Como mostra a Tabela A2.8 do Anexo 2, esta mudança ocorreu num contexto de aumento no número de ocupados pela agricultira, provocado pela rápida expansão dos empregados assalariados.

Houve uma profunda mudança na composição da PEA vinculada à agricultura na década de 70 . A porcentagem de autônomos diminuiu de $72 \%$ para $55 \%$ e a de empregados assalariados aumentou de $27 \%$ para $43 \%$. Simultaneamente, houye pronunciada redução na propọção da PEA com renda turula mas inferior a meio salário mínimo. Esta 
ređução isa incidência da pobreza na agricultura baiana ocorreu em todas as posições na ocupação. Para o conjunto da PEA a proporção de pobres caiu de $40 \%$ para $24 \%$.

$$
\text { Mais do que uma alteração quantitativa, }
$$
houve na década de 70 uma profunda alteração no perfil da pobreza rural na Bahia. Embora em 1980 a maioria dos pobres ainda sejam autônomos (53\%), a proporção dos pobres que são empregados assalariados aumentou de $28 \%$ para $47 \%$. Isso indica gue o desenvolvimento da agricultura no estado em parte reduziu uma das raízes da pobreza rural - a pequena produção de subsistência - mas, de outro lado, contribuiu para o surgimento de uma. "categoria" de pobres - os assalariados -, fenômeno, aliás, comum aos demais estados do Nordesté e ao país como um todo. Outro movimento geral, ocorrido na década. de 70 , que também se manifesta na Bahia, é o forte crescimento da desigualdade da renda dentro da categoria dos autônomos, refletindo provavelmente um processo de diferenciação da produção familiar. o índice de Gini, para a Bahia, cresceu de 0,334 para 0,445 entre os autônomos, enquanto que para o total da PEA agropecuária esse crescimento foi de 0,372 para 0,467 no estado. Em 1970, a composição da PEA por posição na ocupação na Bahia é praticamente a mesma do conjunto dos demais estados nordestinos. Entretanto, a incidência da pobreza é menor no estado da Bahia. Entre 1970 e 1980 a PEA agrícola total também aumentou no resto do Nordeste, porém em ritmo mais 
lento do que o observado na Bahia. A redução no número de autônomos foi semelhante, mas o crescimento dos empregados assalariados foi proporcionalmente muito maior neste último estado, ou seja, a mudança na composição da PEA por posição na ocupação na direção de uma maior importância relativa do trabalho assalariado foi bem mais pronunciada no estado da Bahia. A incidência da pobreza também diminuiu no conjunto dos outros estados dọ Nordeste. Porém, em 1980, a proporção dos pobres no conjunto desses estados é exatamente a mesma observada na Bahia em 1970 (40\%). Finalmente, em consegüência da menor intensidade das transformações na composição da PEA no conjunto dos outros estados do Nordeste, houve uma mudança menos radical no perfil dos pobres. Em 1980, os autônomos constituíam 58\% dos pobres, enguanto que os empregados assalariados perfaziam $41 \%$. o rápido aumento de empregados assalariados e a redução dos autônomos, que provocaram uma forte mudança no perfil dos pobres da agricultura baiana, traduzem em parte uma mudança na distribuição da PEA por microrregião, como mostra a Tabela A2.9 no Anexo 2. Uhama a atenção a queda absoluta da PEA agrícola nas microrregiões de Recôncavo Baiano e Feira de Santana. Nessas duas microrregiões, mesmo em 1980 pesa muito o trabalho não-assalariado e elas também são microrregiões com forte incidência de pobreza. Como ademais a PEA aumentou em microrregiões onde os autônomos ainda tem grande participação e a incidência da pobreza é péquena 
(Chapada Diamantina Setentrional), as mudanças na distribuição do emprego por microrregião contribuíram para reduzir a incidência da pobreza entre os autônomos. Essa redução não foi maior porque a PEA aumentou em regiões com pequena importância relativa de assalariados e alta incidência da pobreza, notadamente em áreas de baixa ocupação do solo como por exemplo Baixo Médio são Francisco. Por outro lado, o emprego aumentou fortemente em microrregiões como a Cacaueira, onde é muito importante o trabalho assaláriado e não é tão elevada a incidência da pobreza.

Em resumo, tem diminuído no estado da Bahia a importância da pequena produção de subsistência na explicação da incidência da pobreza no campo. Não obstante, seu papel ainda é relevante na questão do emprego e distribuição da renda agrícọla, com o que continua presente este aspecto da velha questão da heterogeneidade estrutural, ainda hoje um dos problemas centrais do sub-desenvolvimento.

o presente estudo procurou contribuir para a compreensão desse problema, mostrando uma dada situação de modernização e distribuição de renda na agricultura num corte temporal. Conclusões a respeito dos possíveis efeitos tendenciais do processo de modernização requerem, no entanto, novos estudos sobre as mudanças temporais no padrão da distribuição de renda. 


\section{BIBLIOGRAFIA CITADA}

ANDRADE, Manue1 Correia de. Tradicão e Mudanca. A organizacão do-espaço rural e urbano na área de irriqação do submédio São Francisco. Coleção Agricultura e Sociedade. Rio de Janeiro, 1982 .

CARNEIRO, Ricardo. Agricultura no Nordeste. Revista de EConomia Política 5, vol. 2 no 4, janeiro-março. 1982:123-138 .

CARVALHO, Bernardo M.T. de S. Pacheco de. Modernização da Agricultura: Análise de Seis Culturas no Brasil. Dissertação de Mestrado, ESALQ, USP. Piracicaba, 1982.

FAJNZYLBER, Fernando. Ia Industrialización Trunca de América Latina. México, Editorial Nueva Imagem S/A. 1983.

FUENTES LLANILLO, Rafael. Caracterização da Estrutura de Produção Agropecuária do Estado do Paraná. Piracicaba, DESR/ESALQ/USP. (Dissertação de Mestrado). 
GRAzIANo DA SILVA, José. Proqresso Técnico e Relações de Trabalho na Agricultura. São Paulo, Hucitec, 1981.

GRAZIANO DA SIIVA, José. A Modernização Dolorosa. Rio de Janeiro, Zahar Editores, 1982. (Coleção Agricultura e Sociedade).

HARMAN, Harry H. Modern Factor Analysis. Chicago, The University of Chicago Press, 1976.

HOFFMANN, Rodolfo. Estimação da desigualdade dentro do estrato no cálculo do índice de Gini e da Redundância. Pesquisa e Planejamento Econômico. Rio de Janeiro, 9 (3), 719-738, dezembro de 1979.

HOFFMANN, Rođolfo e VIEIRA, Sônia. Análise de Regressão. Uma Introdução a Econometria. São Paulo, 1983.

HofFMANN, Rodolfo e KAgEYAMA, Angela. "Modernização da Agricultura e Distribuição de kenda no Brasil". Pesquisa e Planejamento Econômico, 15 (1): 171-208, Abril de 1985.

HOFFMANN, Rodolfo et alii. Inovacões Tecnolóqicas e Transformacões Recentes na Agricultura Brasileira. Relatório de Pesquisa FINEP/USP-ESALQ/FEALQ, vol. III, cap. 3, dezembro de 1985 . 
HOFFMANN, Rodolfo e KAGEYAMA, Angela. Distribuição da Renda no Brasil, entre Famílias e entre Pessoas, em 1970 e 1980. Revista Estudos Econômicos 16 (1):25-51, Jan/Abr. 1986.

HOFFMANN, Rodolfo. Distribuicão da Renda e Pobreza na Aqricultura Brasileira. Relatório de Pesquisa. IPEA/USPESALQ/FEALQ. Junho de 1987.

KAGEYAMA, Angela. Modernização, Produtividade e Emprego na Agricultura - Uma Análise Regional. Tese de Doutoramento, IE, Unicamp. Campinas, 1986.

KAGEYAMA, Angela. (coord.). A dinâmica da agricultura brasileira, 1965-1985. Campinas, Convênio IPEA-IPLAN/FECAMP. 1987. (mimeo).

MELo, Mário Lacerda de. Reorganizacão Agrária do Nordeste. SUDENE. Série: Brasil. Estudos Regionais, 3. Recife, 1978.

MINISTÉRIO DA AGRICULTURA. Brasil - INCRA - Sistema Nacional de Cadastro Rural. Informativo Técnico no 4. Zoneamento Agrário 1a Fase, Brasilia, 1978.

SIGAUD, Lygia. Os Clandestinos e os direitos: estudo sobre trabalhadores da cana-de-açúcar de Pernambuco. São Paulo, Duas Cidades, 1979. 260 p. 
SUAREz, Maria Tereza de Mello. Casacos e Corumbas. São Pau10, Atica, 1977. (Ensaios, 33). 


\section{ANEXO 1: MÃO-DE-OBRA EM EQUIVALENTES-HOMEM (E.H)}

\section{Conceito de E.H.}

As pessoas que trabalham nas atividades agrícolas e que compõem a força de trabalho diferenciam-se segundo idade, sexo e situações de emprego. Por este motivo é necessário utilizar uma medida que converta o número de pessoas ocupadas em unidades aproximadamente homogêneas de força de trabalho. Para isto usamos o conceito de equivalente-homem, que representa a força de trabalho de um adulto do sexo masculino durante um ano (300 dias).

\section{Transformação da Mão-de-Obra em equivalente-homem (E.H.)}

A transformação do número de pessoas ocupadas em equivalentes-homem requer a adoção de coeficientes de conversão, que têm um certo grau de arbitrariedade, da- 
da a não disponibilidade de estudos específicos sobre o assunto. Neste trabalho adotamos os coeficientes de conversão propostos por Graziano da Silva e Kageyama e citados por KAGEYAMA (1986:368).

Esses coeficientes são os seguintes:

homem adulto, em qualquer situação $\ldots \ldots \ldots \ldots \ldots 1,0$ EH. não-empregados (responsável e membros não remunerados da família):

- mulher $\ldots \ldots \ldots \ldots \ldots \ldots \ldots \ldots \ldots \ldots \ldots, 0,6 \mathrm{EH}$.

- criança, ambos os sexos (menos de 14 anos) $0,4 \mathrm{EH}$. empregados não-assalariados (parceiros e outra condição) :

. mulher $\ldots \ldots \ldots \ldots \ldots \ldots \ldots \ldots \ldots \ldots \ldots, 0,66 \mathrm{EH}$.

- criança, ambos os sexos (menos de 14 anos) $0,5 \mathrm{EH}$. empregados assalariados (permanentes e temporários):

. mulher ...................... 1,0 EH.

- criança, ambos os sexos (menos de 14 anos) $0,5 \mathrm{EH}$.

A estimativa dos empregados temporários em equivalentes-homem foi obtida calculando $\circ$ número médio mensal de empregados temporários maiores de 14 anos mais 0 número médio de empregados temporários menores de 14 anos ponderados po 0.5. A esse número somou-se uma estimativa dos empregados temporários contratados por empreitada. 
Esta foi estimada dividindo o montante de gastos em empreitadas pelo valor do salário médio diário pago ao trabalhador eventual, fornecido pelo Centro de Estudos Agrícolas da FGV, e dividindo o valor assim obtido por 300 dias. 
Tabela A2 2. (a) Renda média por pessoa, indicadores de desigualdade e de pobreza, considerando a PEA na agropecuária eml1980, excluindo os que declararam renda nula, no Brasil e unidades da federação

\begin{tabular}{|c|c|c|c|c|c|}
\hline $\begin{array}{l}\text { Dinidade } \\
\text { geográfica }\end{array}$ & $\begin{array}{l}\text { Renda ádia } \\
\text { (em. sal. minimo) }\end{array}$ & $\begin{array}{l}\text { Indice de } \\
\text { Gini }\end{array}$ & $10^{+}$ & $\begin{array}{l}\text { Porcentagem } \\
\text { de pobres (b) }\end{array}$ & $\begin{array}{l}\text { Indice de } \\
\text { pobreza de } \text { SEn }^{(b)}\end{array}$ \\
\hline$R O+A C+R R+A P$ & 1,772 & 0,425 & 34,98 & 34,29 & 0,154 \\
\hline$M$ & 1,713 & 0,398 & 32,07 & 34,63 & 0,145 \\
\hline $\mathbf{P A}$ & 1,683 & 0,422 & 37,70 & 39,45 & 0,156 \\
\hline $\mathbf{m H}$ & 0,874 & $0 ; 417$ & 32,26 & $76 ; 81$ & 0,457 \\
\hline PI & 0,732 & 0,420 & 32,61 & 86,46 & 0,544 \\
\hline CE & $0,841$. & 0,414 & 34,32 & 84,36 & 0,481 \\
\hline RK & 0,876 & 0,411 & 34,30 & 83,68 & 0,460 \\
\hline PB & 0,781 & 0,420 & 34,21 & 86,17 & 0,517 \\
\hline PE & 0,907 & 0,418 & 34,76 & 81,77 & 0,447 \\
\hline $\mathbf{A L}$ & 0,908 & 0,427 & 36,27 & 82,52 & 0,453 \\
\hline SE & 1,019 & 0,428 & 36,87 & 77,26 & 0,397 \\
\hline BA & 1,199 & 0,457 & . 40,21 & 70,35 & 0,341 \\
\hline HG & 1,754 & 0,548 & 49,72 & 57,67 & 0,259 \\
\hline ES & 1,970 & 0,554 & 48,83 & 49,73 & 0,229 \\
\hline RJ & 1,760 & 0,539 & 49,38 & 55,51 & 0,242 \\
\hline SP & 2,315 & 0,560 & 51,10 & 37,05 & 0,152 \\
\hline $\mathbf{P R}$ & 2,075 & 0,570 & 50,30 & 48,45 & 0,227 \\
\hline sc & 2,373 & 0,517 & 41,97 & 33,11 & 0,159 \\
\hline RS & 2,668 & 0,594 & 50,39 & 38,83 & 0,198 \\
\hline HS & 2,379 & 0,579 & 53,01 & 39,57 & 0,166 \\
\hline HT & 1,974 & 0,497 & 43,81 & 38,66 & 0,158 \\
\hline 60 & 2,012 & $0 ; 557$ & 49,99 & 49,26 & 0,213 \\
\hline BRASIL & 1,599 & 0,543 & 47,72 & 59,56 & 0,303 \\
\hline
\end{tabular}

(a) Extraido de Hoffmann et.alii (1985, p. 743).

(b) A linha de pobreza considerada corresponde a um salário minimo. 


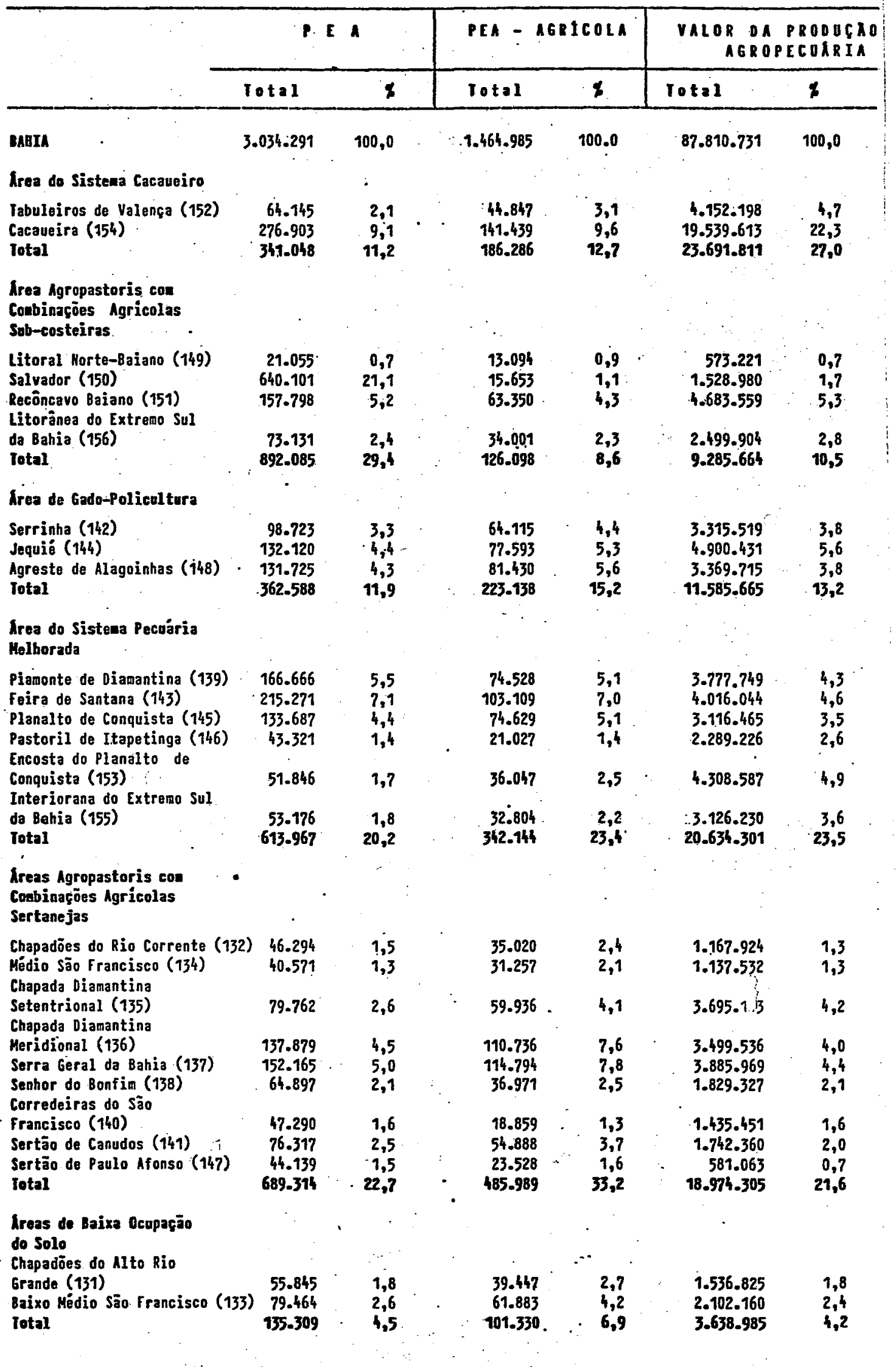

Fonte: IBGE - Censo OEmográfico - Mão-da-obra - 1980.

- Censo Agropecuário - 1980. 


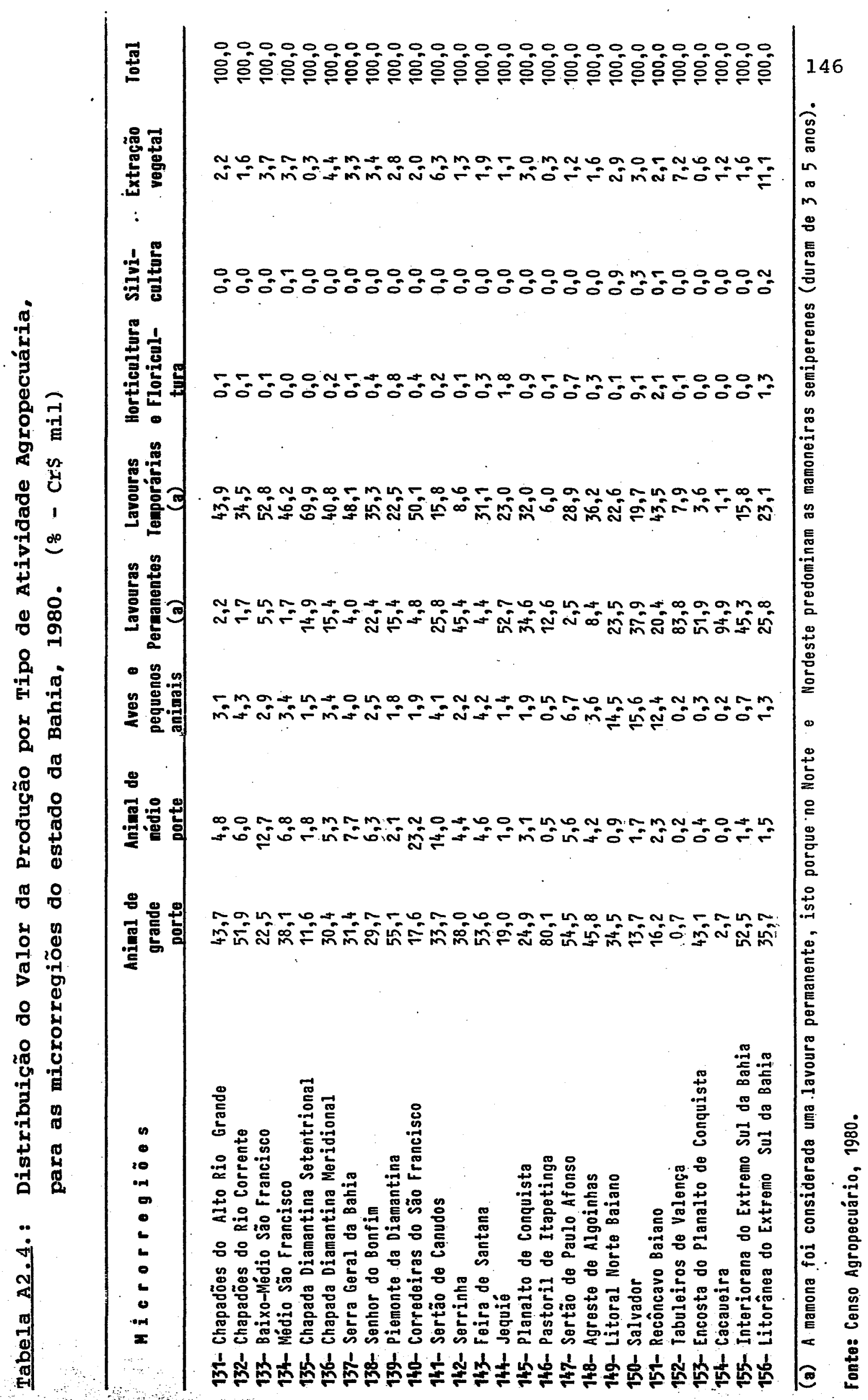




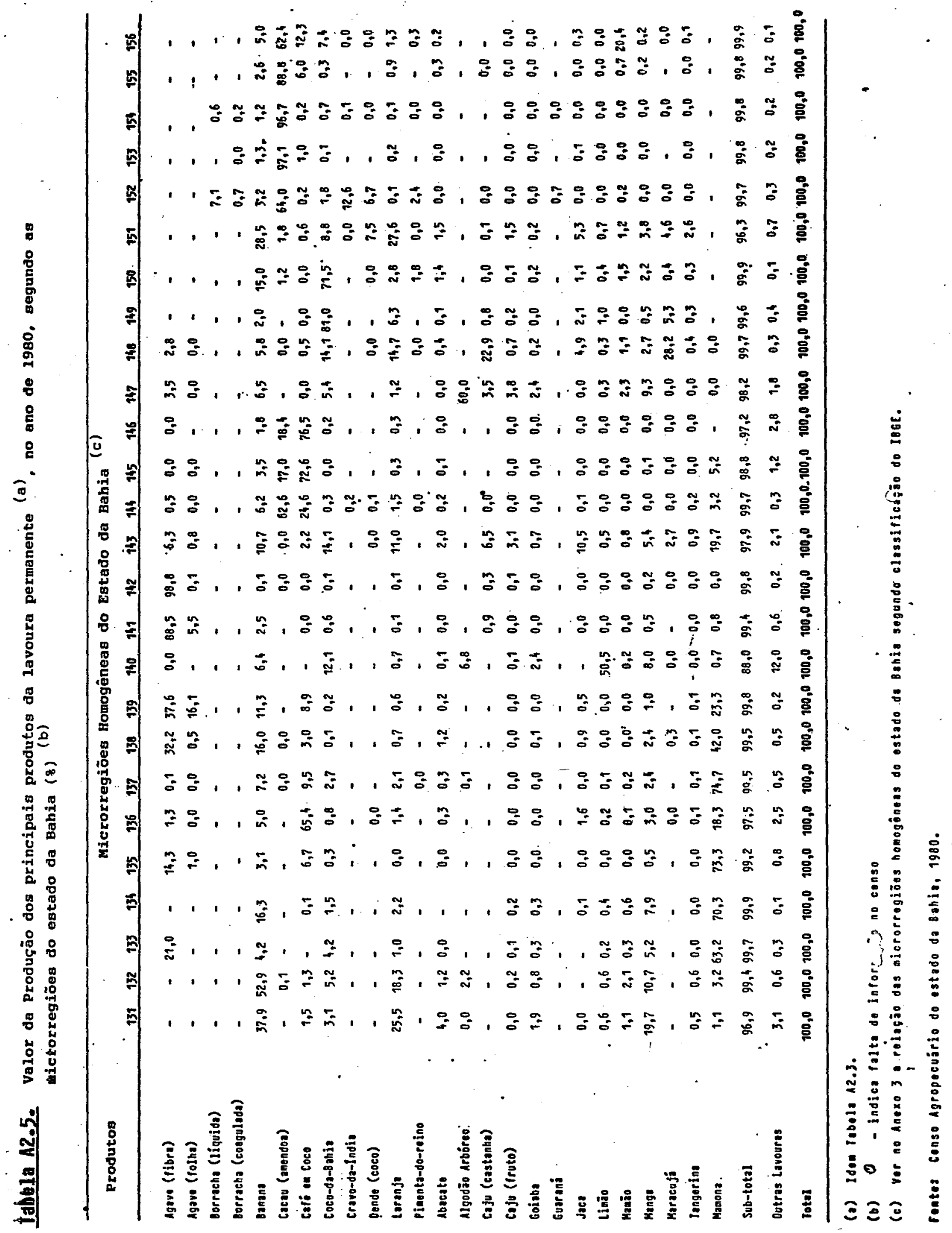




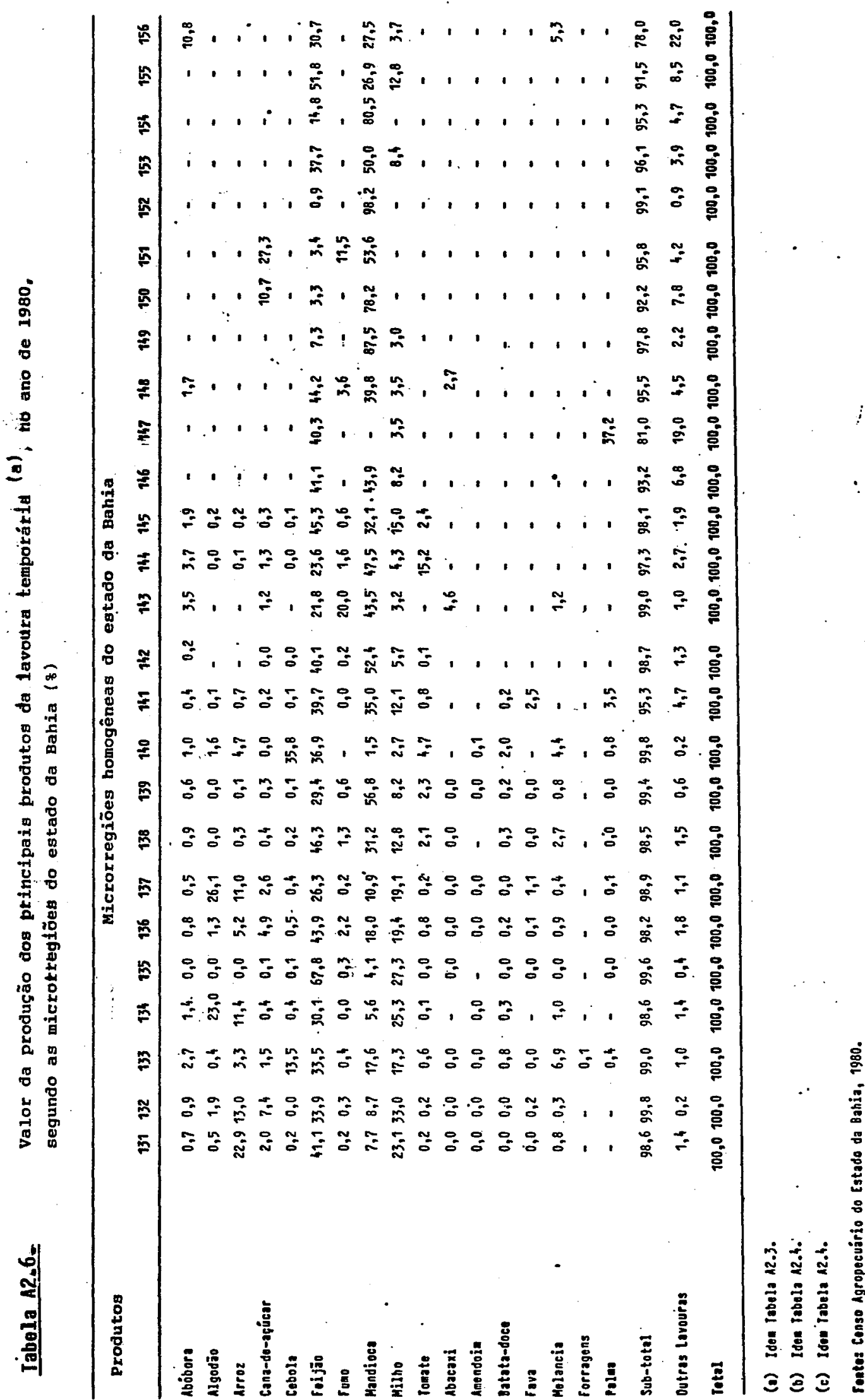




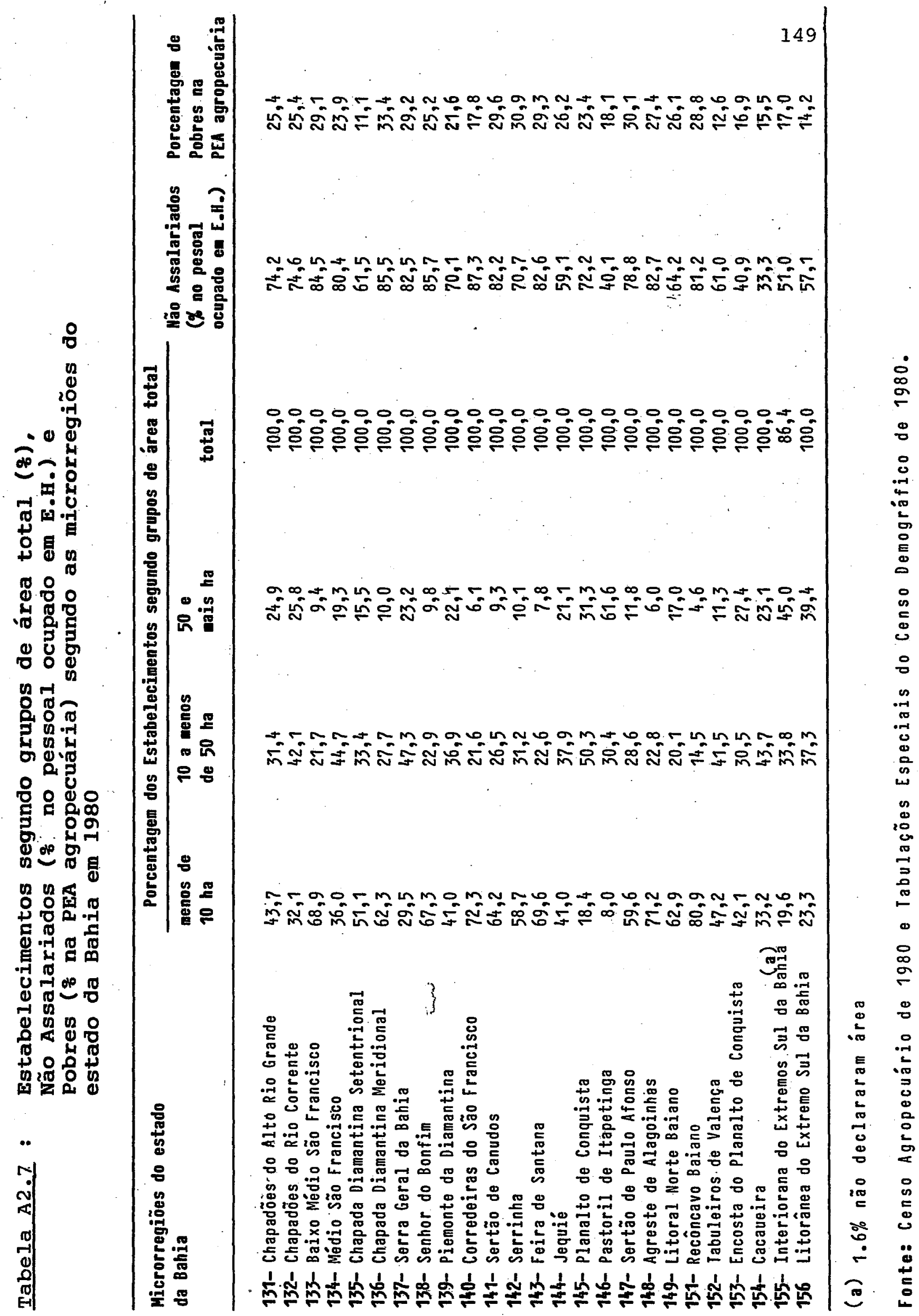




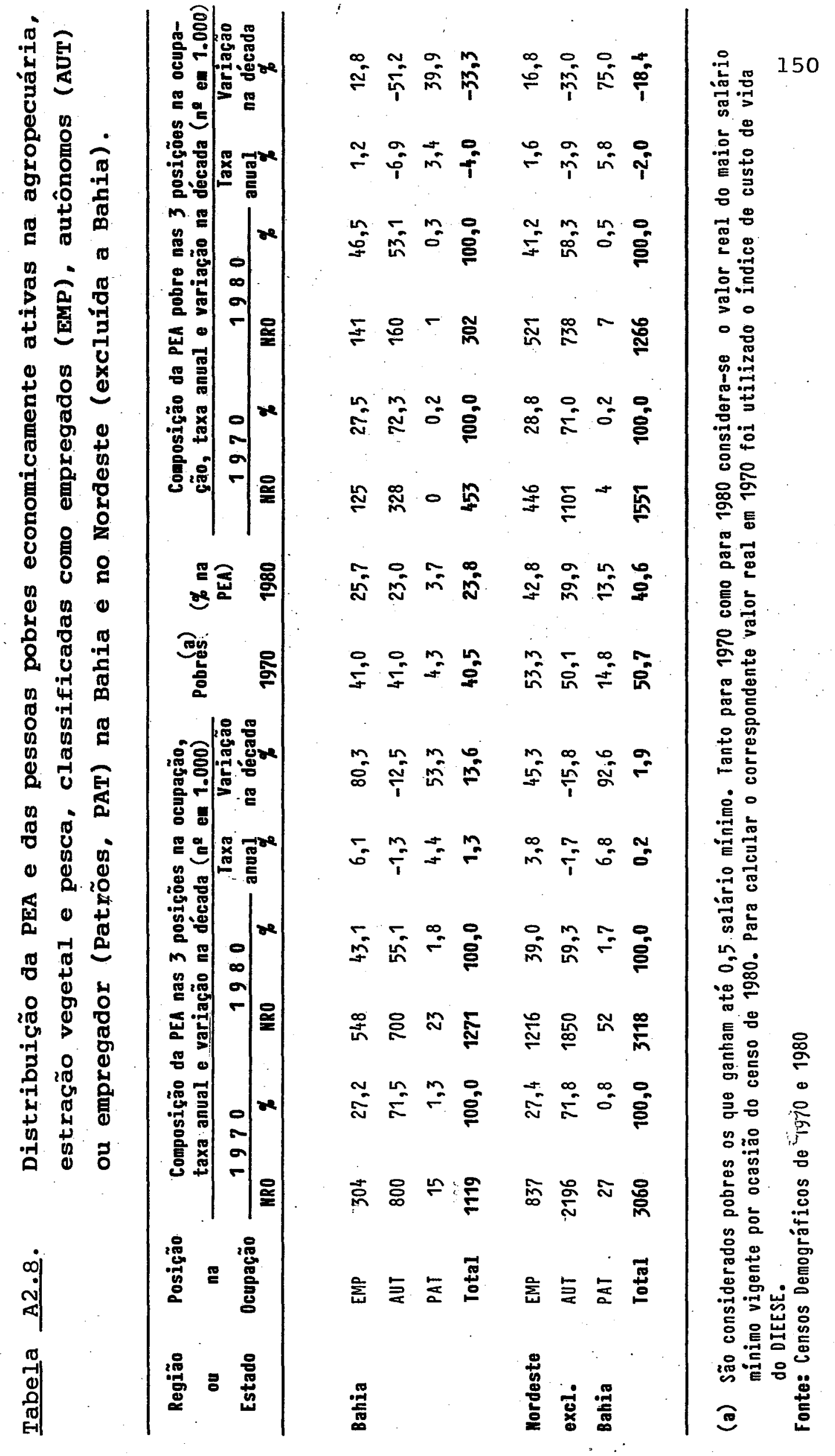




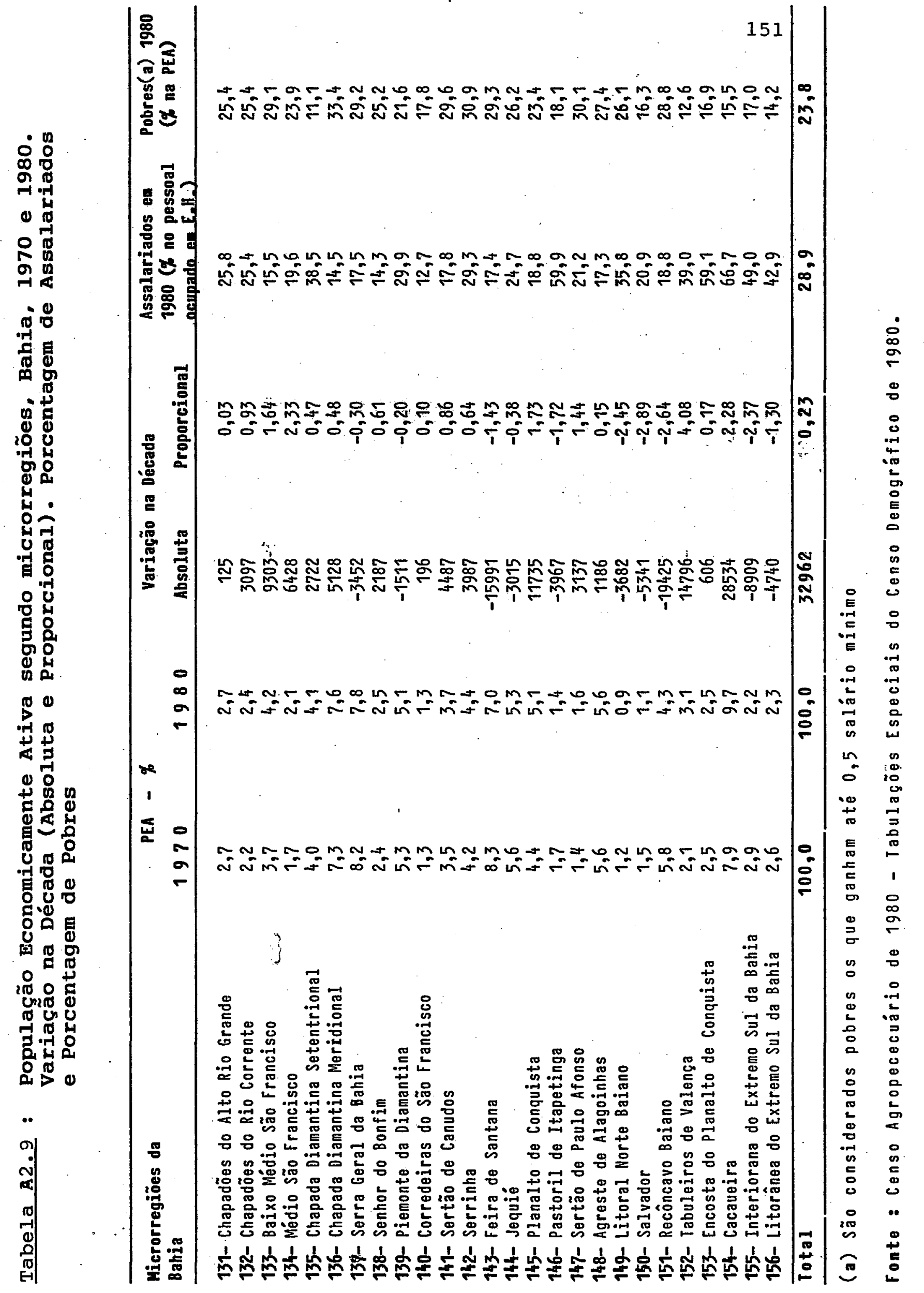




\section{Anexo 3 : RELAÇÃO DAS MICRORREGIÕES HOMOGÊNEAS DO ESTADO DA BAHIA}

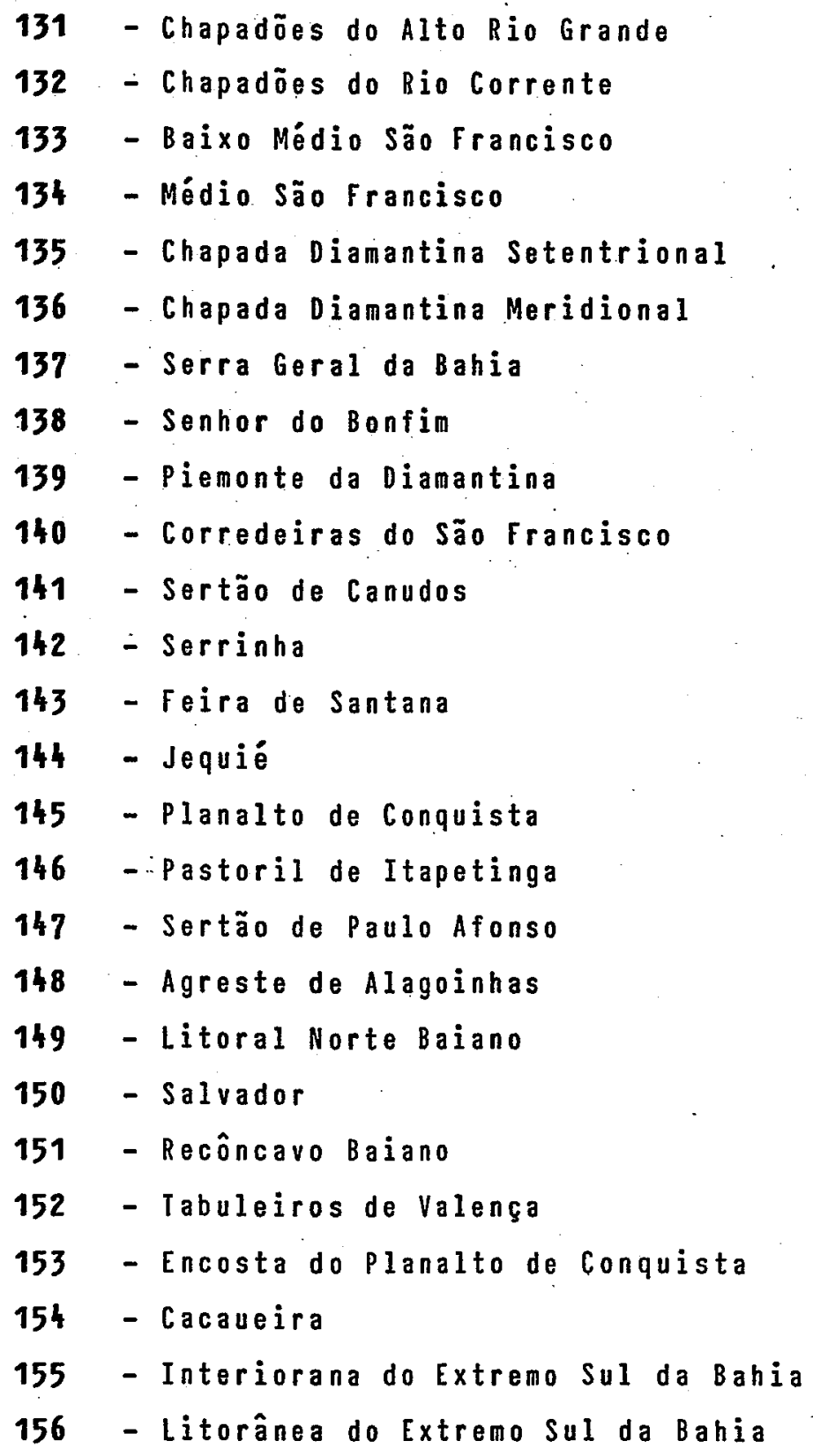

